UNIVERSIDADE DE SÃO PAULO

ESCOLA DE ENFERMAGEM

MICHELLY CHRISTINY MARCONDES NUNES

\title{
ENTRE O IDEALIZADO E O POSSÍVEL: LIMITES DA ASSISTÊNCIA AO PARTO NO CENTRO DE PARTO NORMAL DE UMA MATERNIDADE PÚBLICA
}

SÃO PAULO 2011 


\section{ENTRE O IDEALIZADO E O POSSÍVEL: LIMITES DA ASSISTÊNCIA AO PARTO NO CENTRO DE PARTO NORMAL DE UMA MATERNIDADE PÚBLICA}

Dissertação Apresentada à Escola de Enfermagem da Universidade de São Paulo para obtenção do título de Mestre em Ciências

Área de concentração:

Enfermagem obstétrica e neonatal

Orientadora:

Prof ${ }^{a}$. Dr ${ }^{\mathrm{a}}$. Luiza Akiko Komura Hoga 


\section{AUTORIZO A REPRODUÇÃO E DIVULGAÇÃO TOTAL OU PARCIAL DESTE TRABALHO, POR QUALQUER MEIO CONVENCIONAL OU ELETRÔNICO, PARA FINS DE ESTUDO E PESQUISA, DESDE QUE CITADA A FONTE.}

Assinatura:

Data:

Nunes, Michelly Christiny Marcondes

Entre o idealizado e o possível: limites da assistência ao parto no centro de parto normal de uma maternidade pública / Michelly Christiny Marcondes Nunes. -- São Paulo, 2011.

$199 \mathrm{p}$.

Dissertação (Mestrado) - Escola de Enfermagem da Universidade de São Paulo.

Orientadora: Prof ${ }^{a}$ Dr $^{a}$ Luiza Akiko Komura Hoga

1. Parto - Assistência 2. Parto normal 3. Maternidades 4. Humanização 5. Etnografia 6. Profissionais de saúde I. Título. 
Nome: Michelly Christiny Marcondes Nunes

Título: Entre o idealizado e o possível: limites da assistência ao parto no Centro de Parto Normal de uma maternidade pública

Dissertação apresentada à Escola de Enfermagem da Universidade de São Paulo para obtenção do título de Mestre em Ciências.

Aprovado em:

Banca Examinadora

Prof.Dr. Instituição:

Julgamento: Assinatura:

Prof.Dr. Instituição:

Julgamento: Assinatura:

Prof.Dr. Instituição:

Julgamento: Assinatura: 
Q)edico este trabalho...

Ho meu QDeus e aos meus pais, a quem honro esão referenciais para mim. por me ensinarem a trithar caminhos de vida: wacés sãa a motiva deste sonho ser posssuvel.

Ho meu esposo, querido companheiro, que faz parte desta conquista e de muitas que virão. Qou grata a QDeus por té-lo ao meu lado: viveremos grandes coisas juntos.

Ass minhas tias pela presensa constante nos momentos que mais precisei por me projetarem onde estou haje.

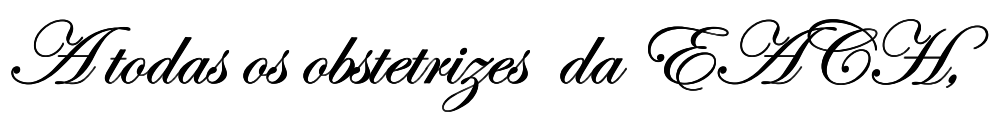
acs que simpatizam com nossa causa e que lutam para que as mulheres e suas familias sejam atendidas de forma digna. 


\section{AGRADECIMENTOS}

Primeiramente a Deus, pois sei que sempre está ao meu lado, a Ele que é minha força nos momentos de fraqueza e alegria nos momentos de tristeza, rocha da minha salvação que alicerça os meus projetos.

Aos meus pais, Marcos Antonio e Elizete Lipari, que me deram a vida e me ensinaram a viver com dignidade.

Ao meu esposo Junior, pela compreensão e valiosa ajuda que me deu durante a pesquisa.

Aos meus tios e aos meus sogros, meu especial carinho e agradecimento.

À Prof. Dra. Luiza Hoga, que, no tempo de convivência, contribuiu para meu crescimento científico e intelectual.

À Prof ${ }^{\mathrm{a}}$. Dr ${ }^{\mathrm{a}}$. Dulce Gualda, por ter idealizado o curso de obstetrícia e pelo incentivo para realizar o mestrado.

Ao Prof. Dr. Edimilson Antunes, pela atenção e pelo apoio durante o processo de definição e orientação.

A todos os professores do curso de obstetrícia da EACH-USP, por perseverarem e acreditarem na mudança da assistência.

Aos meus cunhados, Adna e Robert, pela revisão do inglês.

Aos administradores e profissionais do Hospital e Maternidade Municipal Amador Aguiar pela colaboração neste estudo.

Aos funcionários da Secretaria de Pós-Graduação e da Biblioteca da Escola de Enfermagem pelo suporte.

À Coordenação de Aperfeiçoamento de Pessoal de Ensino Superior, pela concessão da bolsa de mestrado. 
Nunes MCM. Entre o idealizado e o possível: limites da assistência ao parto no Centro de Parto Normal de uma maternidade pública [dissertação]. São Paulo: Escola de Enfermagem, Universidade de São Paulo, 2011.

\section{RESUMO}

As transformações no modelo de assistência ao parto e nascimento e a criação de Centros de Parto Normal (CPN) no âmbito do Sistema Único de Saúde (SUS) remetem à importância de explorar a assistência ao parto neste contexto. O presente estudo teve o objetivo de compreender e descrever as crenças e os valores que norteiam as práticas dos profissionais em um CPN. Foi utilizada a abordagem qualitativa de pesquisa e o método etnográfico em um CPN de uma maternidade pública localizada na cidade de Osasco, Estado de São Paulo, Brasil. Os dados foram coletados por meio do processo de observação participante e de entrevistas etnográficas. Foram entrevistados todos os membros da equipe profissional, composta por enfermeiro obstetra, técnico de enfermagem, médico obstetra e médico neonatologista, que estavam diretamente envolvidos na assistência ao parto, e os gestores da instituição. A análise indutiva e interpretativa dos dados resultou em quatro subtemas culturais, que correspondem a cada uma das categorias profissionais: Enfermeira obstetra: "Este CPN não é como deveria ser: inúmeros obstáculos dificultam a prestação da assistência humanizada ao parto"; Técnicas de enfermagem: "Fazendo o que é possível: satisfação com a assistência que é prestada mediante superação de muitas dificuldades"; Médico obstetra: "Um árduo cotidiano que impede o desenvolvimento da assistência desejada"; Médico neonatologista: "Dificuldades existem porque são comuns no serviço público, mas há satisfação em relação à assistência prestada no CPN". Destes subtemas culturais emergiu o tema cultural "Entre o idealizado e o possível: os limites na assistência humanizada ao parto", que representa o cotidiano da assistência ao parto no CPN que foi foco desta pesquisa. As limitações para o desenvolvimento da assistência humanizada ao parto estavam relacionadas, não somente aos problemas relativos à precariedade da estrutura física e de recursos humanos ou aos déficits provocados pelo financiamento insuficiente da assistência ao parto. Estavam envolvidos também as crenças e os valores dos profissionais e o seu grau de envolvimento com a filosofia de humanização da assistência ao parto. Contatou-se que a efetivação da assistência humanizada ao parto, como preconizada pelos organismos nacionais e internacionais, depende da superação das inúmeras dificuldades descritas neste estudo. Um grande desafio deste âmbito está representado pela necessidade de articulação entre a grade curricular dos cursos da área da saúde com os fundamentos da Medicina Baseada em Evidências Científicas. Portanto, é de fundamental importância a existência de serviços exemplares, que prestam assistência humanizada ao parto, para os estudantes de graduação e para os profissionais.

PALAVRAS-CHAVE: Parto-Assistência, Parto Normal, Maternidades, Humanização, Etnografia, Profissionais de saúde. 
Nunes MCM. Between the idealized and the possible: the boundaries of the deliveries in a birth center [dissertation]. Sao Paulo: University of Sao Paulo. School of Nursing. (SP), Brazil; 2011.

\begin{abstract}
The transformation in the model of childbirth assistance and the creation of Birth Centers within the Brazilian Unified Health System referred to the importance of exploring the delivery assistance. This study aimed to understand and describe the beliefs and values that guide the practice of professionals in a Birth Center. We used a qualitative research approach and ethnographic method was developed in a Birth Center in a public hospital at the city of Osasco, São Paulo, Brazil. Data were obtained through the process of participant observation and ethnographic interviews. We interviewed all members of the professional team consisting of nurse midwife, technical nurse assistant, obstetrician and neonatologist physician, who were directly involved in delivery care and management of the institution. The inductive analysis and interpretation of data resulted in four sub-cultural themes, which correspond to each of the professions: nurse midwife: "The Birth Center is not as it should be, many obstacles interfere on a humanized assistance of a childbirth; Technical nurse assistant: "Doing what is possible: satisfaction with the giving assistance throught overcoming many difficulties"; Obstetrician Doctor: "A hard routine restrains the development of a good assistance; Medical neonatologist:" Difficulties exist because they are common in the public service, but there is a satisfaction in relation to the assistance provided at the Birth Center. " From sub-cultural themes emerged a cultural theme "Between the idealized and the possible: the limits in the humanized delivery care", which represents the everyday care delivery in the Birth Center that was the focus of this research. The limitations for the development of humanized childbirth were related not only to problems related to the precarious physical infrastructure and human resources or deficits caused by insufficient funding of childbirth care. They were also involved in the beliefs and values of professionals and their degree of involvement with the philosophy of humanization of childbirth care. It was noted that the effectiveness of humanized delivery care, as recommended by national and international organizations, depends on overcoming the several difficulties described in this study. A major challenge in this context is represented by the need to articulate the courses academic subjects in the health field with the fundamentals of Scientific Evidence-Based Medicine. Therefore it is very importante to the existence of exemplary service to the graduate students and professionals.
\end{abstract}

KEYWORDS: Birth-Care, Childbirth, Maternity, Humanization, Ethnography, Health professionals. 


\section{LISTA DE FIGURAS}

Figura 1 - Ciclo da Pesquisa Etnográfica. Fonte: Spradley, 1980 ...................... 38

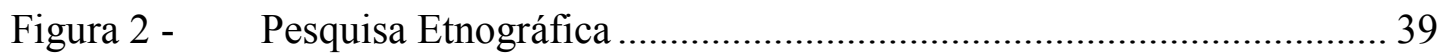

Figura 3 - $\quad$ Fluxo Assistencial do Centro de Parto Normal................................... 58

Figura 4 - $\quad$ Os descritores culturais, os subtemas e o tema cultural .................. 172 


\section{LISTA DE QUADROS}

Quadro 1 - Enfermeiras obstétricas e suas características. São Paulo, 2011........ 64

Quadro 2 - $\quad$ As Técnicas de Enfermagem e suas características. São Paulo,

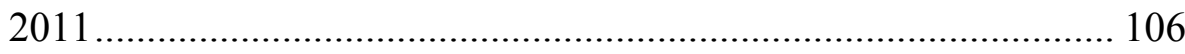

Quadro 3 - Os médicos Obstetras e suas características.

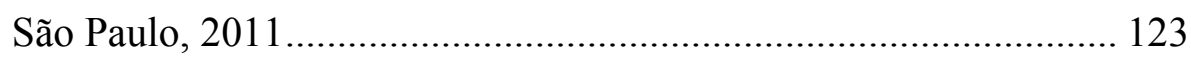

Quadro 4 - Os médicos neonatologistas e suas características.

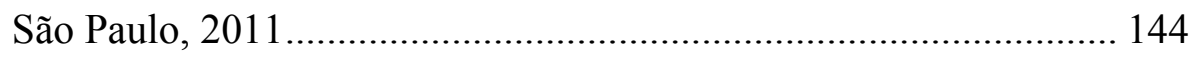


LISTA DE SIGLAS E ABREVIATURAS

CPN

CO

OMS

SUS

MS

TP

OP

RN

REHUNA
- Centro de Parto Normal

- Centro Obstétrico

- Organização Mundial de Saúde

- Sistema Único de Saúde

- Ministério da Saúde

- Trabalho de Parto

- Observação Participante

- Recém-nascido

- Rede de Humanização do Parto e Nascimento

RELACAHUPAN - Rede Latino-Americana de Humanização do Parto e Nascimento 


\section{SUMÁRIO}

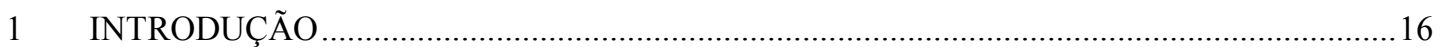

1.1 A TRAJETÓRIA DA INVESTIGADORA E SEU INTERESSE PELO TEMA ................. 16

2 OBJETIVO

3 ASPECTOS HISTÓRICOS DA ASSISTÊNCIA AO PARTO E O SURGIMENTO DOS

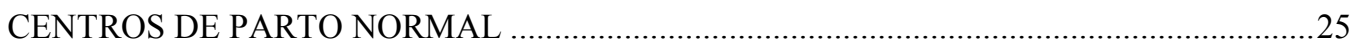

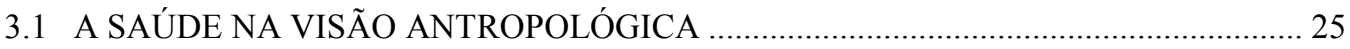

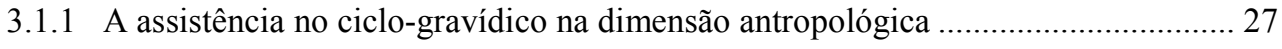

3.2 ASPECTOS HISTÓRICOS DO MOVIMENTO DE HUMANIZAÇÃO DA

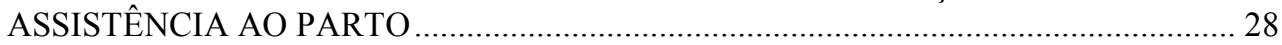

3.3 A HUMANIZAÇÃO DO PARTO NO BRASIL: O SURGIMENTO DOS CPN ……........ 31

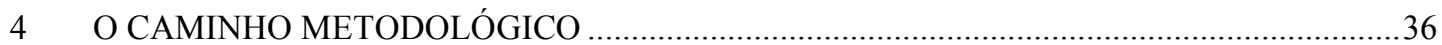

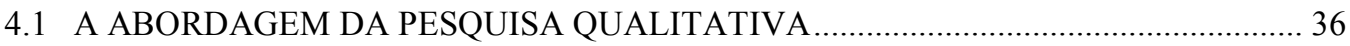

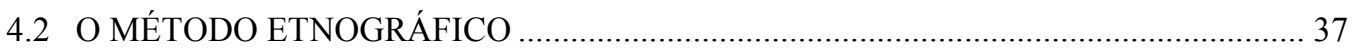

4.3 COLETA DAS INFORMAÇÕES ETNOGRÁFICAS …………………………............... 39

4.3.1 As entrevistas etnográficas .............................................................................. 41

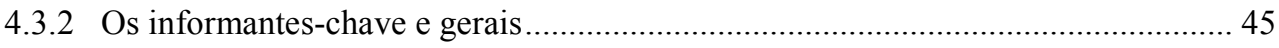

4.4 OS ASPECTOS ÉTICOS E A AUTORIZAÇÃO PARA O DESENVOLVIMENTO

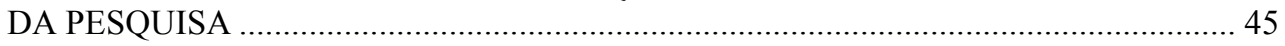

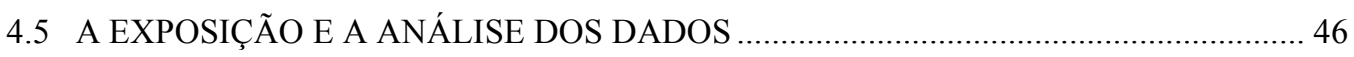

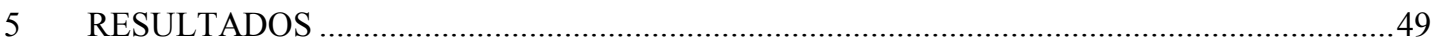

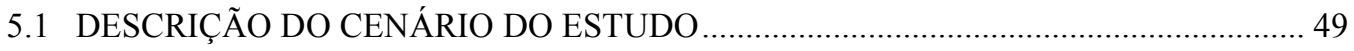

5.2 DADOS ESTRUTURAIS E DE ASSISTÊNCIA DO CENTRO DE PARTO

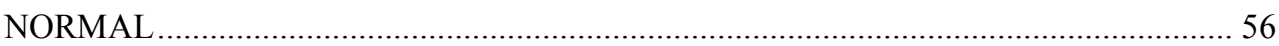

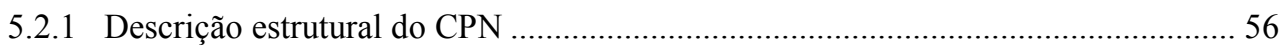

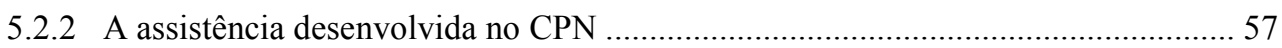

5.3 AS ENFERMEIRAS OBSTÉTRICAS, SUAS CARACTERÍSTICAS, SUAS NARRATIVAS, O ESQUEMA CONCEITUAL E O SUBTEMA CULTURAL............... 64

5.4 AS TÉCNICAS DE ENFERMAGEM, SUAS CARACTERÍSTICAS, SUAS NARRATIVAS, O ESQUEMA CONCEITUAL E O SUBTEMA CULTURAL............. 106

5.5 OS MÉDICOS OBSTETRAS, SUAS CARACTERÍSTICAS, SUAS NARRATIVAS, O ESQUEMA CONCEITUAL E O SUBTEMA CULTURAL............. 123

5.6 OS MÉDICOS NEONATOLOGISTAS, SUAS CARACTERÍSTICAS, SUAS NARRATIVAS, O ESQUEMA CONCEITUAL E O SUBTEMA CULTURAL

5.7 O TEMA CULTURAL: ENTRE O IDEALIZADO E O POSSÍVEL: OS LIMITES DA ASSISTÊNCIA HUMANIZADA AO PARTO

6 DISCUSSÃO DOS RESULTADOS, CONSIDERAÇÕES FINAIS E LIMITAÇÕES DO ESTUDO 
6.2 CONSIDERAÇÕES FINAIS E AS IMPLICAÇÕES PARA O ENSINO E A

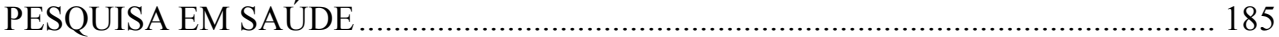

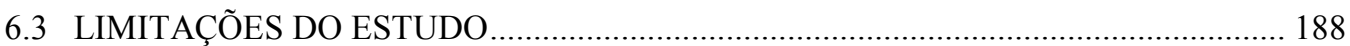

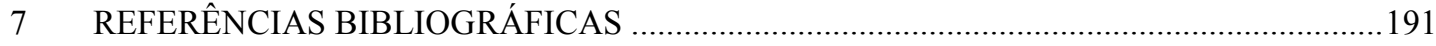

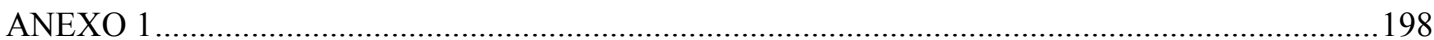

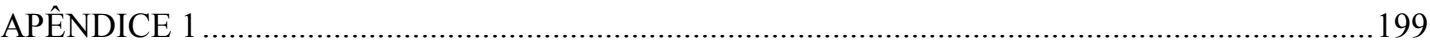


"(...) a situação da maternidade é culturalmente determinada, sobre e acima de sua natureza biológica."

(Malinowski apud Herzberg, E, 1930). 
Neste capítulo introdutório, a trajetória da investigadora como egressa da primeira turma do Curso de Obstetrícia da Escola de Artes, Ciências e Humanidades da Universidade de São Paulo (EACH-USP) e o seu interesse pela temática da assistência ao parto na perspectiva antropológica são apresentados. Nesta pesquisa, foi enfocada a perspectiva da assistência ao parto no contexto de um Centro de Parto Normal (CPN), considerando-a enquanto cenário permeado por crenças e valores culturais profundamente arraigados. A escassez de estudos enfocando esta temática e as justificativas do desenvolvimento deste estudo finalizam a introdução desta dissertação.

$\&$

\subsection{A TRAJETÓRIA DA INVESTIGADORA E SEU INTERESSE PELO TEMA}

A existência de índices alarmantes caracteriza a atual assistência obstétrica desenvolvida no Brasil. Destacam-se nesta realidade, a alta morbidade e mortalidade materna e neonatal, o aumento no número de nascimentos de recémnascidos $(\mathrm{RN})$ prematuros, a alta prevalência de procedimentos invasivos realizados de maneira rotineira e a violência institucional contra as gestantes.

Dados encontrados na pesquisa "Mulheres brasileiras e gênero nos espaços público e privado" (Fundação Perseu Abramo, 2010) revelaram que 25\% das mulheres sofrem algum tipo de violência institucional enquanto recebem assistência ao parto. A divulgação destes resultados gerou grande repercussão na mídia, no meio acadêmico e nas instituições públicas. Os índices de cesariana também estavam muito distantes dos limites estabelecidos pelas instituições. Neste aspecto, a Organização Mundial de Saúde estabeleceu que a prevalência da cesárea não deve 
ultrapassar o limite de 15\% (OMS, 1996). Entretanto, no Brasil, a prevalência da cesárea está em torno de $45 \%$ na rede pública de saúde e chega a $90 \%$ na rede privada. Estes dados revelam a precariedade da assistência ao parto neste país.

$\mathrm{Na}$ tentativa de reverter esta situação problemática da assistência ao parto, surgiu uma grande mobilização nas esferas públicas e nos meios acadêmicos. No Sistema Único de Saúde (SUS), houve a criação das Casas de Parto e dos Centros de Parto Normal. Na esfera acadêmica, foi criado o Curso de Graduação em Obstetrícia na Escola de Artes, Ciências e Humanidades da Universidade de São Paulo (EACH - USP), em 2005. Trata-se de curso desenvolvido em período integral, com quatro anos e meio de duração, o único neste país que forma o profissional obstetriz. Em síntese, este profissional é formado para fazer o acompanhamento da gestação, do parto e do pós-parto de baixo-risco. Ressalta-se que em países desenvolvidos, como o Canadá e a Nova Zelândia, a melhoria dos indicadores obstétricos foi conseguida a partir de investimentos feitos na formação deste profissional.

Sou obstetriz egressa da primeira turma de obstetrícia da EACH-USP e o meu interesse pela temática deste estudo está intimamente relacionado com a formação obtida neste curso. Para demonstrar as inter-relações entre a minha trajetória e a realização desta pesquisa, esboço um breve panorama sobre o Curso de Obstetrícia e seus encaminhamentos, uma vez que a sua criação faz parte da história do movimento da assistência humanizada ao parto no Brasil.

O obstetriz, conhecido como "midwife" ao redor do mundo, tem seu foco de atenção profissional voltado à maternidade. O foco deste profissional é a preservação da fisiologia do processo de nascimento, desempenhada mediante prestação de assistência direta à gestante no pré-natal e no parto normal de baixo risco, entre outras atividades que fazem parte de sua profissão. Tem grande respeito à mulher enquanto protagonista do próprio parto e evita a realização de intervenções desnecessárias.

Este Curso de Obstetrícia tem recebido o apoio de inúmeras redes, movimentos e escolas de obstetrícia de todo o mundo. Janet Balaskas, fundadora do movimento internacional pelo parto ativo, que veio a primeira vez ao Brasil para se 
manifestar a favor do Curso de Obstetrícia e da inserção das obstetrizes no mercado de trabalho brasileiro, é uma grande defensora do profissional obstetriz. A Rede Latino-Americana de Humanização do Parto e Nascimento (RELACAHUPAN) também se posicionou favoravelmente ao Curso de Obstetrícia, conforme consta no trecho extraído da Carta de Apoio, que foi enviada por esta Rede.

Nosotras, la Red Latinoamericana y del Caribe por la Humanización del Parto y Nacimiento y la Alianza Internacional de Parteras cotejamos y evaluamos la educación que se imparte en la Obstetricia da Escola de Artes, Ciências e Humanidades da Universidade de São Paulo. Nuestra conclusión es: Que su curso de Obstetricia excede a la educación de excelencia para las parteras u obstetrices. Es similar a la de los países desarrollados que aumentan las estadisticas nacionales de salud y vida de la madre y bebé.

Os movimentos em favor da humanização da assistência ao parto também ocorreram no Brasil. Em abril de 2011, em um ato realizado na Avenida Paulista (na cidade de São Paulo), centenas de mulheres se manifestaram favoráveis ao Curso de Obstetrícia, em conjunto com obstetrizes, médicos, enfermeiras e outros ativistas da humanização do parto. Nesta manifestação, foram reafirmadas as evidências científicas que indicaram que as obstetrizes favorecem a ocorrência do parto fisiológico de mulheres saudáveis. Além disso, o envolvimento desta profissional com a assistência ao parto está associado aos melhores resultados maternos e neonatais. Em um abaixo-assinado de apoio distribuído nesta manifestação e pela internet constavam mais de 13.000 assinaturas.

O início desta história nos remete a Londres, Inglaterra, onde, no ano de 1982, cerca de seis mil pessoas foram às ruas contra a imobilização das parturientes no leito, a proibição de acompanhantes, a realização de episiotomia de rotina, e outras intervenções dolorosas e desnecessárias. Naquele país, há quase 30 anos, o movimento organizado de mulheres, sob a liderança de Janet Balaskas, conseguiu acabar com estas práticas que ainda acontecem em no Brasil.

Para representar as obstetrizes de modo efetivo e legal, participei ativamente da fundação, em 5 de maio de 2011, da Associação de Alunos e Exalunos do Curso de Obstetrícia da Universidade de São Paulo (AO-USP). Faço parte 
da diretoria desta Associação, que tem como principal objetivo o incentivo do espírito de união e solidariedade entre os componentes desta categoria profissional, a promoção da tomada de consciência sociopolítica de seus integrantes, o desenvolvimento técnico-científico, cultural e profissional que favoreça o avanço da profissão, a articulação com as demais entidades representativas da obstetrícia e áreas afins, na defesa dos interesses da profissão, entre outros aspectos.

Minha formação também foi fundamental para despertar, em mim, o olhar para os aspectos socioculturais que envolvem a assistência ao parto. Portanto, esta pesquisa se insere na temática da antropologia médica, mais especificamente a análise do nascimento humano.

Avalia-se que o discurso antropológico na abordagem da saúde e da doença é extremamente pertinente, uma vez que ele se refere a fenômenos complexos que envolvem fatores biológicos, sociológicos, econômicos, ambientais e culturais, como refere Uchôa (1994, p. 497):

\footnotetext{
O discurso antropológico [...] nos revela que o estado de saúde de uma população é associado ao seu modo de vida e ao seu universo social e cultural. A antropologia médica se inscreve, assim, numa relação de complementaridade com a epidemiologia e com a sociologia da saúde. A antropologia considera que a saúde e o que se relaciona a ela são fenômenos culturalmente construídos e culturalmente interpretados.
}

Diversos estudos contemporâneos que enfocaram esta temática têm focalizado os diferentes valores culturais e as relações sociais de poder que se explicitam na assistência ao nascimento. Kay (1982), nos estudos apresentados em seu livro "Antropologia do Nascimento Humano", propôs que, para se compreender o porquê de uma mulher dar à luz de determinada maneira, a cultura inteira que a envolve deve ser compreendida e descrita. Para esta estudiosa da assistência ao parto, as crenças e as práticas no parto se relacionam com a organização social de cada sociedade e com o seu sistema político e econômico.

Neste trabalho, a perspectiva antropológica da assistência ao parto foi adotada. Isto foi feito para compreender a instituição segundo a perspectiva cultural numa visão abrangente, de modo a proporcionar o conhecimento das concepções e práticas envolvidas na assistência ao parto. Desse modo, foi desenvolvido um estudo 
de um cenário cultural específico, um CPN de uma instituição vinculada ao SUS. Acredita-se que a descrição sistematizada deste cenário possa contribuir para a identificação e a descrição dos problemas que porventura possam estar permeando a assistência ao parto e indicar possibilidades para sua superação.

A inauguração deste CPN resultou de uma política pública implementada pelo Ministério da Saúde. Em 1999, esta instituição do governo federal instituiu o Projeto Casas de Parto e Maternidades-Modelo, em consideração às experiências positivas de funcionamento das casas de parto (Brasil, 1999). Em seguida, foi divulgada a Portaria de criação do Centro de Parto Normal, entendida como uma unidade de saúde que deve prestar atendimento humanizado e de qualidade, destinada exclusivamente à assistência ao parto normal sem distócia (Brasil, 1999).

As casas de parto e, em seguida, os CPN, foram criados para atender parturientes sem patologias clínicas e ou obstétricas. Estas instituições constituiriam alternativas possíveis à humanização da assistência ao nascimento e parto. $\mathrm{O}$ exemplo positivo conquistado pela primeira Casa de Parto da Cidade de São Paulo, que foi inaugurada em 1998 com o objetivo de oferecer assistência humanizada às mulheres com gestação físiológica, representou, para a comunidade profissional e acadêmica, um modelo inovador da assistência ao parto (Hoga, 2001). Foi esta casa, em razão dos resultados positivos demonstrados após um ano de sua implementação, que serviu como referência em termos de assistência às futuras casas que se encontram em projeção no território nacional (Brasil, 1999).

Acreditou-se que estes CPN constituem locais privilegiados de atuação da profissional obstetriz, que é o meu caso. Avaliei, entretanto, que estas instituições devem ser sistematicamente estudadas, pois a criação delas já data de algum tempo. Desta forma, este estudo foi desenvolvido com a finalidade de clarear as seguintes questões: Como são desenvolvidas as práticas de assistência ao parto em um CPN? Será que as práticas assistenciais desenvolvidas nessas instituições estão de acordo com os padrões de assistência ao parto preconizados em âmbito nacional e internacional? Quais são as crenças e os valores que permeiam o desenvolvimento das práticas assistenciais desenvolvidas nessas instituições? Para responder estes 
questionamentos, foi desenvolvida esta pesquisa, com o objetivo de compreender e descrever as crenças, os valores e as práticas dos profissionais atuantes neste modelo.

Acreditou-se que tais crenças, valores e práticas podem estar presentes também em outros CPN vinculados ao SUS. Avaliou-se, sobretudo, a necessidade de uma descrição sistemática deste Centro de Parto para que ela possa indicar as diretrizes para o aperfeiçoamento das práticas de assistência ao parto neste cenário.

A literatura científica enfoca a perspectiva da mulher que recebe assistência nestes centros de parto. Entretanto, as pesquisas que enfocam a perspectiva institucional e dos profissionais ainda são muito reduzidas ou quase inexistentes. Avalia-se que esta realidade decorre do fato dos CPN serem estruturas recentemente implementadas e, portando, ainda não sujeitas à investigação. A identificação desta lacuna no conhecimento a respeito dos $\mathrm{CPN}$, segundo a perspectiva cultural, também justificou a realização desta pesquisa. 


\section{OBJETIVO}




\section{OBJETIVO}

Compreender e descrever as crenças e os valores que norteiam as práticas dos profissionais atuantes em um Centro de Parto Normal. 
ASPECTOS HISTÓRICOS DA ASSISTÊNCIA AO PARTO E O SURGIMENTO DO CENTRO DE PARTO NORMAL 


\section{ASPECTOS HISTÓRICOS DA ASSISTÊNCIA AO PARTO E O SURGIMENTO DOS CENTROS DE PARTO NORMAL}

Este capítulo faz uma retrospectiva histórica da assistência ao parto e do local de nascimento e sua relação com a dimensão antropológica da saúde no contexto brasileiro. Descreve o surgimento dos Centros de Parto Normal no Brasil.

$\&$

\subsection{A SAÚDE NA VISÃO ANTROPOLÓGICA}

A antropologia é uma área de estudo que tende a descobrir propriedades gerais que caracterizam toda a vida em sociedade. Segundo Levi-Strauss (1954):

\footnotetext{
A antropologia tem por objetivo um conhecimento global do homem, abarcando o que lhe diz respeito em toda a sua extensão histórica e geográfica; aspirando um conhecimento aplicável ao conjunto do desenvolvimento humano desde, digamos, os hominídeos até as raças modernas; e tendendo a conclusões positivas ou negativas, mas válidas para todas as sociedades humanas, desde a grande cidade moderna, até à mais pequena tribo melanésia.
}

Portanto, a antropologia apareceu como uma ciência da diferença e da diversidade, que permitiu desenvolver uma perspectiva crítica frente às nossas verdades mais fundamentais, favorecendo a construção de uma nova abordagem, por exemplo, sobre o corpo, a saúde e a doença.

Por meio da abordagem antropológica se desenvolveu importante aparelhagem conceitual e metodológica para o estudo sistemático das maneiras culturais de pensar e de agir associadas à saúde. Ela permitiu examinar as relações 
(interações e contradições) entre os modelos de prática, que suportam a organização dos serviços, os programas de prevenção e as intervenções terapêuticas, e os modelos culturais dos usuários. A partir daí, ela forneceu parâmetros para a reformulação da questão da adequação sócio-cultural dos diferentes programas de saúde. (Uchoa, 1994)

A antropologia não é uma disciplina definida por um objeto particular as sociedades primitivas. É a maneira de pensar que se impõe quando o objeto é o outro e que exige nossa própria transformação. Trata-se de aprender a ver o que é nosso como se fossemos estrangeiros - e como se fosse nosso o que é estrangeiro. $\mathrm{Na}$ perspectiva antropológica, o outro passa a ser definido a partir de suas especificidades sociais e culturais. A definição do "Outro" é sempre relativa, isto é, depende da posição onde se coloca o "Eu".

A noção de cultura é um instrumento fundamental para se estudar e compreender o outro. A cultura é o contexto no qual os diferentes eventos tornam-se inteligíveis. É uma "lente" através da qual vemos e damos sentido ao mundo social. Ela é forma que determinado grupo social estabelece para classificar as coisas e atribuir-lhes um significado. A cultura é melhor vista não como complexos de padrões concretos de comportamento (costumes, usos, tradições, feixes de hábitos), mas como um conjunto de mecanismos de controle - planos receitas, regras, instruções para governar o comportamento (Geertz, 1978).

Para Geertz (1978), a cultura é a teia de significados que o homem teceu, a partir da qual ele olha o mundo e onde se encontra preso. É ativa e participativa e abrange estrutura de significados aos quais as pessoas dão sentido às experiências, se comunicam, interagem e desenvolvem seu conhecimento e suas atividades em relação às suas vidas.

Da Matta (1981) apontou que na antropologia é preciso recuperar o lado extraordinário e estático das relações entre pesquisador e nativo. Este é o lado mais difícil e menos comum de ser apanhado da situação antropológica, certamente porque ele se constitui no aspecto mais humano de nossa rotina. É o que realmente permite escrever a boa etnografia porque sem ele perde-se a questão interpretativa. 
A antropologia não negou o caráter universal de certos fenômenos biológicos (o corpo, a doença, a saúde), mas procurou entender o significado específico que esses fenômenos assumem numa dada sociedade, visto que os registros de normalidade e anormalidade são, fundamentalmente, determinados a partir de valores próprios a um contexto sociocultural específico.

\subsubsection{A assistência no ciclo-gravídico na dimensão antropológica}

Por isso, para propor a consolidação do novo paradigma assistencial que é a assistência humanizada ao parto e nascimento, além dos movimentos sociais organizados e daqueles que lidam com a medicina perinatal, surge a contribuição da antropologia. É nesta perspectiva que Gualda (2002) apontou a importância da antropologia para a compreensão das "evidências culturais" que formatam o processo de nascimento nas diferentes sociedades e culturas. $\mathrm{O}$ aspecto biológico universal e os aspectos socioculturais da parturição são intrinsicamente articulados, possibilitando abordar o parto e a assistência obstétrica em uma nova perspectiva, como um evento sociocultural, emocionalmente rico e medicamente seguro.

Assim, se é certo que o parto tem uma fisiologia universal, também é correto que cada sociedade, em todas as épocas, desenvolveu uma forma específica para cuidar desse evento crítico na vida humana. Dessa maneira, pensados em uma perspectiva socioantropológica, o parto e o nascimento foram concebidos como simbolicamente construídos dentro de uma configuração sociocultural específica.

O movimento de diversas antropólogas compõe o que ficou conhecido como a 'Antropologia do Parto'. Dentre elas pode-se citar Brigitte Jordan, Robbie Davis-Floyd, Sheila Kitizinger e Caroline Sargent. Elas realizaram estudos nesta abordagem em diversos lugares do mundo, mas estes estudos aqui no Brasil ainda precisam ser melhor delineados.

Brigitte Jordan (1979) definiu, em seu livro "Birth in four cultures", o parto e o nascimento como um evento universal, ao mesmo tempo, fisiológica e culturalmente determinado. Portanto, que está inserido no contexto das normas 
sociais de cada cultura. Por exemplo, numa cultura onde ninguém está no controle do nascimento, uma ferramenta especializada (fórceps) não tem lugar, por conseguir derrotar a igualdade de todos os participantes.

O papel das obstetrizes é assistir a família a tomar suas decisões. Como um contraste, num país onde o nascimento é hospitalizado, o nascimento frequentemente se torna uma doença que precisa ser tratada - a mãe se torna paciente e o médico se torna responsável. O livro "Nascimento em quatro culturas" mencionou uma variedade de lições que a cultura do nascimento pode ensinar: o papel das mulheres na sociedade, como o nascimento é definido (natural vs médico), através de uma comparação da experiência do nascimento nos Estados Unidos com outros países (Jordan, 1979).

Para uma revisão vasta do tema destacou-se, entre outras, a coletânea de Robbie Davis-Floyd e Carolyn Sargent (Davis-floyd,1997), com um extenso levantamento na literatura antropológica. Nos poucos anos que se passaram depois dessa coletânea, houve número crescente de estudos sobre parto no mundo inteiro, inclusive no Brasil. Esses trabalhos, partindo de diversas bases conceituais e disciplinares, têm, muitas vezes, procurado o diálogo e a interfecundação na abordagem dos seus objetos.

\subsection{ASPECTOS HISTÓRICOS DO MOVIMENTO DE HUMANIZAÇÃO DA ASSISTÊNCIA AO PARTO}

O conceito humanização do parto foi atribuído pelo Ministro da Saúde e sua equipe técnica ao Programa de Pré-natal e Nascimento, com a premissa de melhorar as condições do atendimento neste âmbito (MS, 2000). Este conceito é bastante diversificado, porém, há um movimento defendendo-o como um processo que respeita a individualidade das mulheres, valorizando-a como protagonista do processo de nascimento e parto e permitindo a adequação da assistência à cultura, às crenças, aos valores e à diversidade de opiniões das próprias das mulheres (Rattner, 1998). 
Largura (2000) definiu a humanização do parto como sendo respeitar e criar condições para que todas as dimensões do ser humano sejam atendidas, ou seja, as espirituais, psicológicas e biológicas do processo de nascimento e parto.

O tema relativo à humanização da assistência ao parto já foi debatido e utilizado há mais de 40 anos. Casate e Correa (2005), ao realizar uma revisão bibliográfica acerca deste tema, constataram a existência de artigos produzidos no âmbito da saúde, especialmente de enfermagem, desde os fins da década de 1950.

Os principais sentidos atribuídos à humanização do parto compreendiam a solidariedade, o doar-se pelo próximo até as indagações mais atuais, do final do século 20, do discurso dos direitos do cidadão, combinando os direitos sociais, em geral, e direitos reprodutivos e sexuais, em especial.

O conceito de humanização, portanto, possui múltiplos sentidos; porém, foi identificada, na literatura científica, a existência de sentidos diversos em relação à humanização. Este termo é referido muitas vezes segundo a perspectiva oposta, ou seja, a violência simbólica, a violação dos direitos humanos, a instituição de rotinas e práticas sem o embasamento nas evidências científicas, o uso irracional da tecnologia como substitutivo da relação profissional-cliente, a falta de equidade e acesso aos serviços e o acolhimento inadequado dos clientes (Deslandes, 2005).

As críticas em relação aos modelos de assistência ao parto se desenvolveram há muito tempo. Na Europa, na década de 1950, surgiu o movimento do parto sem dor, os ativistas do movimento Dick-Read, o parto sem medo, e o parto sem violência, com o método Lamaze e Leboyer. Na década de 1960, outra vertente iniciada foi a do movimento hipiie e da contracultura, onde firmou-se o parto natural, cuja maior expressão conhecida deu-se nos EUA na comunidade "The Farm”, sendo Ina May Gaskin a parteira que se consagrou por seus três mil partos assistidos, tendo sido 95\% deles domiciliares (Gaskin, 2003; Diniz, 2005).

O feminismo teve papel central, nas décadas de 1960 e 1970, com a criação de centros de saúde feministas e os Coletivos de Saúde das Mulheres. Posteriormente, as feministas redescreveram a assistência a partir dos conceitos de direitos reprodutivos e sexuais como direitos humanos (Diniz, 2005). 
No campo da medicina, o auge da reflexão sobre a humanização do atendimento apontou na década de 1970. Naquela época havia um olhar crítico a respeito deste tema, sobretudo em relação à impessoalidade do modelo médico profissional, à falta de informação e ao protagonismo dos clientes diante de sua terapêutica. Em 1972, ocorreu o simpósio nacional "Humanizando o Cuidado em Saúde" em São Francisco (EUA), do qual derivou uma publicação com o mesmo título (Deslandes, 2005).

Em 1979 foi publicado o livro "Bases fisiológicas y psicológicas para el manejo humanizado del parto normal", de autoria de Caldeyro-Barcia, no qual se avaliou que o modelo de assistência vigente era inadequado e se propuseram mudanças na compreensão das dimensões anatomo-fisiológicas e emocionais do parto. Esta publicação provocou impacto sobre o discurso médico, pelo fato de ter sido escrita por um pesquisador renomado no âmbito da fisiologia obstétrica - os princípios contidos no livro foram recebidos com hostilidade por seus companheiros.

Na saúde pública, a crítica do modelo tecnocrático se acelerou em 1979, com a criação de um comitê europeu para estudar as intervenções para reduzir a morbimortalidade perinatal e materna no continente. A partir daí houve grande incentivo internacional, através de uma revisão exaustiva dos procedimentos obstétricos. No ano de 1993, foi feita uma revisão sistemática de cerca de 40.000 estudos sobre o tema, realizados a partir de 1950. Uma síntese deste trabalho foi publicada pela primeira vez pela OMS, em 1996, e tornou-se conhecida como as "Recomendações da OMS". Uma coletânea completa destas revisões foi coordenada por Murray Enkin em 1995 como uma versão popular dirigida aos profissionais e às usuárias. Estes foram alguns passos de um movimento que foi denominado como medicina baseada em evidências (Cochrane,1989; Diniz,2005).

No final do século 20, houve crescimento mundial do movimento de reformulação dos modelos de assistência à saúde, no sentido de incorporar as evidências empíricas e visando a segurança e a efetividade dos procedimentos, em todas as especialidades médicas. No caso da assistência à gravidez e ao parto, esta preocupação com a evidência foi considerada crucial, uma vez que, diferentemente das outras especialidades, estas práticas irão intervir sobre mulheres e crianças 
supostamente saudáveis, no contexto de um processo supostamente normal, como é o caso do parto (Chalmers, 1992).

No âmbito da antropologia, a partir da década de 1970 começaram a surgir questionamentos relativos à assistência ao parto. A Antropologia do Parto foi iniciada como uma forma de visualizar a assistência como construto social, que possui variabilidade cultural e caráter ritual, tanto nas sociedades primitivas quanto nas complexas. Neste âmbito, foram agregados o conceito dos conhecimentos autoritativos, de Jordan, as concepções de Davis-Floyd e Sargent, a abordagem psicossexual do parto, de Sheila Kitizinger, a proposta de parto ativo, de Janet Balaskas, a redescrição da fisiologia do parto, de Michel Odent, e a parte sexual associada a este momento, de Naolí Vinaver.

\subsection{A HUMANIZAÇÃO DO PARTO NO BRASIL: O SURGIMENTO DOS CPN}

No Brasil, as discussões em torno deste tema foram impulsionadas por experiências em vários estados. Na década de 1970 surgiram profissionais inspirados em práticas de parteiras e índios, como Galba de Araújo, no Ceará, Moisés Paciornik, no Paraná, Hospital Pio X, em Goiás, e Instituto Aurora, no Rio de Janeiro. As discussões se intensificaram a partir de década seguinte, a partir dos amplos movimentos de redemocratização política e, especialmente, pelo movimento de mulheres, que discutiam pautas relacionadas aos direitos sexuais e reprodutivos e as críticas ao modelo hegemônico (Diniz, 2005).

Na década de 1980, o projeto Casas de Parto foi implantado em 44 municípios do Estado da Bahia. A equipe era constituída por uma coordenadora, a enfermeira obstetra, quatro agentes de saúde e dois agentes de portaria, que atuavam em regime de dedicação exclusiva. Era prestada assistência pré-natal, ao parto natural, visita domiciliar à puérpera e à criança. Este serviço deixou de existir algum tempo depois (Bittencourt,1984). 
Em São Paulo, a primeira Casa de Parto funcionou na Comunidade Monte Azul a partir da experiência realizada no ambulatório inaugurado em 1979, da mesma comunidade. Ângela Gehrke da Silva, de origem alemã, praticava o parto humanizado, num ambiente aconchegante e com a presença do acompanhante. Os índices perinatais alcançados equiparavam-se aos melhores encontrados em países desenvolvidos da Europa. Porém, a casa fora fechada em 1999 pelo Conselho Regional de Enfermagem sob a alegação de que o diploma de Ângela não era reconhecido no Brasil (Osava, 1997).

Inspirada na Casa de Parto da Associação Comunitária Monte Azul, em 1998, foi aberta a Casa de Parto de Sapopemba com o objetivo de oferecer atendimento digno e humanizado às mulheres com gestação de baixo risco. Todo o atendimento obstétrico e neonatal era realizado por enfermeiras obstétricas com longa experiência na área, apoiadas por auxiliares de enfermagem. Não havia médicos na unidade e os casos que fugiam à normalidade eram transferidos para os serviços de referência (Hoga, 2001).

Em 1999, o Ministério da Saúde instituiu o CPN no âmbito do SUS, incentivando sua implementação no país. Ele foi preconizado como uma unidade independente, intra ou extra-hospitalar e constitui espaço de atuação e autonomia da obstetriz e da enfermeira obstetra. Oferecem ambiente acolhedor, similar ao domicílio, com equipamentos e infraestrutura técnica e recursos humanos adequados ao parto normal sem distócias.

Apesar de, no Brasil, a assistência em CPN ser uma modalidade inovadora, existem estudos internacionais mostrando resultados maternos e neonatais favoráveis a esse novo modelo assistencial (Campbell, 1999).

Hodnett (2003) encontrou diferenças significativas entre os resultados referentes a alguns indicadores de processo da assistência. Segundo a meta-análise, que incluiu somente estudos randomizados, mulheres atendidas em casas de parto utilizaram em menor extensão métodos farmacológicos para o alívio da dor e ocitocina para a aceleração do trabalho de parto. Menor quantidade de mulheres foi submetida à episiotomia e impedida de se movimentar e deambular durante o 
trabalho de parto. Foram observadas anormalidades na frequência cardíaca fetal em menor número, assim como incidência menor de partos cirúrgicos.

Em 2000, o Ministério da Saúde lançou o Programa Nacional de Humanização da Assistência Hospitalar. Na sequência, foram publicados novos documentos, como a Política Nacional de Humanização, a Norma de Atenção Humanizada do Recém-Nascido de Baixo Peso, o Programa de Humanização do Parto e a Humanização no Pré-Natal e Nascimento. Tais programas e diretrizes foram acompanhadas por diretrizes técnicas importantes, tais como os manuais "Parto, Aborto e Puerpério - Assistência Humanizada à mulher", "Atenção Humanizada ao Recém-Nascido de baixo peso" e o "Método Canguru" (Deslandes, 2005).

Em Itapecerica da Serra, o Centro de Parto Normal segue os procedimentos definidos pelo órgão gestor máximo do país para a atenção à mulher durante o parto e o nascimento. Esta unidade, cujos partos são atendidos por enfermeiras obstétricas, realizou 10.559 partos normais no período compreendido entre janeiro de 2000 e janeiro de 2003 (Machado, 2005). Em março de 2002, foi inaugurada a Casa de Maria, localizada no bairro do Itaim Paulista, Município de São Paulo, funcionando anexa a uma maternidade.

Segundo Diniz (2001) este movimento de mudança na assistência obstétrica envolveu legitimidade profissional e corporativa e requereu um redimensionamento dos papéis desempenhados e dos poderes dos elementos envolvidos na cena do parto. Demandou o deslocamento do médico, que em outro cenário detém a função principal no parto normal, para a obstetriz e a enfermeira obstetra, tal como legitimado pelo MS. Além disso, há o deslocamento do cenário do parto, do centro cirúrgico, palco atual desta ação, para a sala de parto ou casa/centro de parto.

No início de 2003, houve um debate no MS defendendo a priorização do tema da humanização como aspecto fundamental a ser contemplado nas políticas públicas de saúde. O debate se fazia a partir da tensão entre concepções diferentes e foi se inserindo em torno das condições precárias de trabalho, das dificuldades de pactuação das diferentes esferas do SUS, do descuido e da falta de compromisso na 
assistência ao usuário dos serviços de saúde. O diagnóstico ratificava a complexidade da tarefa, de se construir um modo eficaz no sistema público que garantisse o acesso universal, equânime e integral a todos os cidadãos (Benevides, 2005).

Neste sentido, foram feitos investimentos na produção de um novo tipo de interação entre os sujeitos que constituem os sistemas de saúde e retomada a perspectiva de rede descentralizada e co-responsável, que alicerça o Sistema Único de Saúde. A humanização da atenção e da gestão em saúde no SUS se apresentava como meio para qualificar as práticas de saúde. Isto seria feito mediante o acolhimento, a atenção integral e equânime com responsabilização e vinculação, a valorização dos trabalhadores e usuários e o consequente avanço na democratização da gestão (Benevides, 2005). 
O CAMINHO METODOLÓGICO 


\section{O CAMINHO METODOLÓGICO}

Neste capítulo são abordados o paradigma qualitativo de pesquisa e a justificativa para sua adoção nesta pesquisa. São apresentados o método de pesquisa etnográfica e seus fundamentos, situando-os no mundo atual. É descrito o processo de coleta de dados e de realização das entrevistas no contexto cultural desenvolvido, respeitando os princípios éticos e de rigor em pesquisa qualitativa. Ao final, há uma explanação sobre a forma como foram analisados os dados.

$\&$

\subsection{A ABORDAGEM DA PESQUISA QUALITATIVA}

Esta pesquisa foi desenvolvida por meio da abordagem qualitativa, que propicia conhecimento profundo e sistematizado sobre o que se deseja investigar. As estratégias qualitativas indicam o que é importante estudar no dado contexto sociocultural, permitem identificar variáveis pertinentes e formular hipóteses culturalmente apropriadas ao final.

A pesquisa qualitativa parte de questões amplas, que se definem ao longo do estudo, não havendo hipóteses estabelecidas a priori, separação sujeito-objeto, generalização ou manipulação de variáveis. Ela se caracteriza por um conjunto de atividades interpretativas, procurando "compreender os fenômenos estudados segundo a perspectiva dos sujeitos, ou seja, dos participantes da situação em estudo" (Denzin, Lincoln, 2005).

A abordagem qualitativa postula a existência de um vínculo dinâmico e indissociável entre o mundo objetivo e a subjetividade do sujeito. Outra característica importante apontada é o fato da pesquisa qualitativa buscar os dados em seu ambiente natural e, portanto, a habilidade e a experiência do pesquisador são 
fundamentais na coleta destes dados. Esta abordagem de pesquisa visa à compreensão do conjunto de fatores que permeiam o fenômeno por meio da revelação das interações humanas, símbolos, valores, estilos de vida e visão de mundo que o cercam. Busca-se obter a "verdade" das pessoas em sua essência (Sandelowski, Barroso, 2002).

Segundo Angrosino (2009), a pesquisa qualitativa se propõe a entender, descrever e explicar fenômenos sociais, de diversas maneiras diferentes. Isto deve ser feito por meio da análise das experiências de indivíduos ou grupos, o exame das interações e comunicações que estejam se desenvolvendo em dado cenário ou contexto e a investigação de documentos (textos, imagens, filmes ou músicas) ou traços semelhantes de experiências ou interações.

\subsection{O MÉTODO ETNOGRÁFICO}

Dentre os métodos qualitativos conhecidos, o etnográfico se destaca como um dos mais importantes. Oriundo da antropologia, consagrado pelos antropólogos Boas e Malinowski, este método envolve um conjunto particular de procedimentos metodológicos e interpretativos, utilizados para o estudo dos grupos humanos desde o final do século 19 e início do 20.

A definição de etnografia, que literalmente significa a descrição de um povo, dá lugar a um largo acordo, quaisquer que sejam as "escolas" e as orientações nacionais.

[...] o que se propõe é um olhar de perto e de dentro, mas a partir dos arranjos dos próprios atores sociais [...]. Esta estratégia supõe um investimento em ambos os pólos da relação: de um lado, sobre os atores sociais, o grupo e a prática que estão sendo estudados e, de outro, a paisagem em que essa prática se desenvolve, entendida não como mero cenário, mas parte constitutiva do recorte de análise (Magnani, 2002, p.18).

Pode-se dizer que o paradigma etnográfico pode assumir um caráter, diferenciado, na medida em que esteja mais ou menos marcado pela visão do todo, pela preocupação com o significado e, conforme o estudo, seja direcionado para o 
diagnóstico ou para a explicação dos fenômenos. O que importa nesses estudos não é a forma de que os fatos se revestem, mas, sim, o seu sentido (Sanday, 1979).

Para Geertz (1989), fazer etnografia no sentido de construir uma leitura é como tentar ler uma manuscrito estranho, desbotado, apresentando incoerências, tendências e elipses, resultantes de comportamentos modelados.

Assim, a realização desta pesquisa deu-se por meio de etnografia local, objetivando a observação sistemática e a compreensão das crenças e dos valores que os profissionais, do HMMAA, possuem na assistência humanizada, relacionados aos códigos socioculturais próprios ao contexto no qual estão inseridos.

A experiência etnográfica da assistência no Centro de Parto Normal da Maternidade Amador Aguiar foi construída a partir de observação, transcrição, análise e reconstituição dos elementos históricos da cultura.

O seguinte ciclo para a pesquisa etnográfica proposto por Spradley (1980) foi seguido durante a pesquisa:

Figura 1 - $\quad$ Ciclo da Pesquisa Etnográfica. Fonte: Spradley, 1980

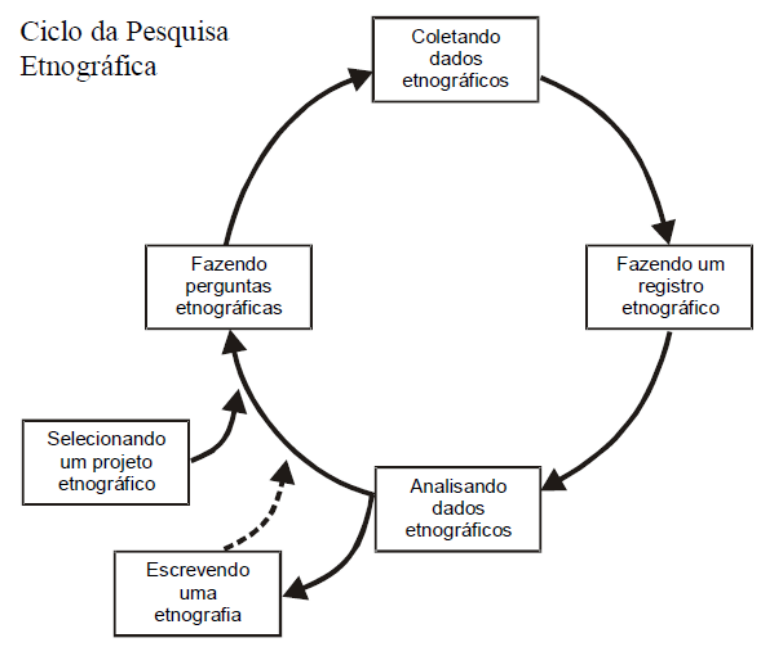




\subsection{COLETA DAS INFORMAÇÕES ETNOGRÁFICAS}

Iniciou-se a pesquisa com observações descritivas gerais, numa tentativa de traçar um panorama da situação social e do que ocorre ali. Schatzman e Strauss (1973) sugerem que um mapeamento inicial do local a ser estudado seja feito. Esses autores falam sobre três tipos de mapas:

a) mapa social (número e tipos de pessoas, hierarquia, divisão de trabalho...);

b) mapa espacial (localização das pessoas, equipamentos, salas...);

c) mapa temporal (fluxo de pessoas, horários, reuniões, rotinas...);

Depois de registrar e analisar as informações iniciais coletadas, a pesquisa se estreitou e começou-se a fazer observações focalizadas. Finalmente, após mais análises e repetidas observações em campo, foi possível estreitar a investigação e fazer observações específicas. A figura 2 ilustra a passagem de observações gerais, descritivas, para observações focalizadas até a chegada a observações seletivas e específicas. Fica claro nesta figura que até o final da pesquisa não se abandonou as observações gerais, ou seja, o conjunto da situação estudada.

Figura 2 - Pesquisa Etnográfica.

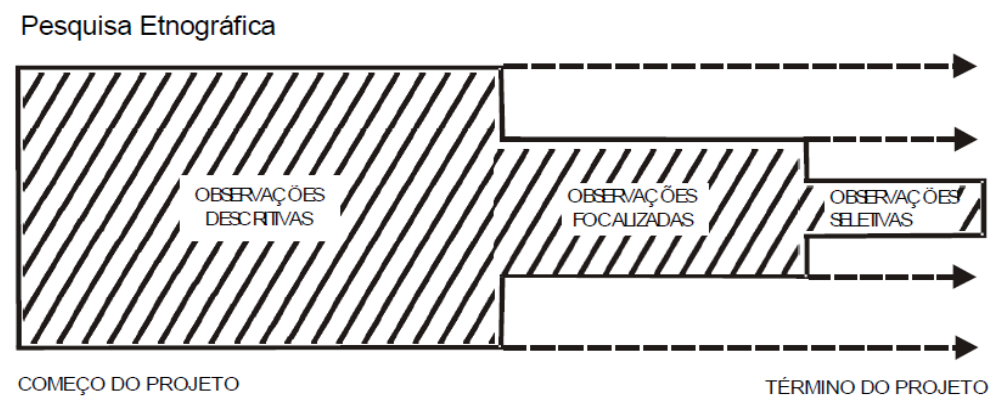

Fonte: Spradley, J. (1980, p.34). Tradução nossa.

Portanto, foi adotado, nesta pesquisa, o Processo de Observação Participante, segundo Spradley (1980), que se constitui de três fases: a observação primária e escuta ativa, ou sem participação ativa, que constitui a primeira fase preconizada pelo método. Em seguida, a observação primária, com maior ênfase 
participativa, e a fase de participação, que consiste em maior ênfase na participação das atividades próprias ao grupo.

A observação participante implica uma explicação do cenário cultural, uma relação dos participantes e suas descrições, uma cronologia de eventos, uma descrição do cenário físico e dos objetos materiais dentro dele, descrever os comportamentos e as interações, um registro das conversações e outras interações verbais que existam no contexto observado (Angrosino, 2009).

Para a observação participante, utilizamos o roteiro a seguir na observação das práticas dos profissionais que atuam no $\mathrm{CPN}$ na atenção à parturiente:

- O dia típico da maternidade, de modo genérico

- O cotidiano dos profissionais da atenção ao parto no contexto do CPN, de forma detalhada

- A utilização dos espaços e recursos dentro do CPN (cama de parto, banheira, bola, chuveiro, banco para parto de cócoras, etc)

- As práticas desenvolvidas pelos profissionais antes, durante e após o parto

Durante o processo de observação participante do contexto cultural, todos os profissionais colaboraram, em maior ou menor grau, esclarecendo as dúvidas e respondendo aos questionamentos feitos.

\section{O processo de observação participante da Maternidade Amador}

Aguiar iniciou-se em novembro de 2009. A observação preliminar da Maternidade Amador Aguiar com vistas a esta pesquisa foi feita pela própria pesquisadora, que acompanhou ativamente as atividades corriqueiras dos profissionais, por meio de visitas no período de um ano e nove meses. Essas visitas foram intensas nos primeiros meses, todos os dias, até chegarem a dias intercalados, com espaçamento maior de tempo. Nessas ocasiões, houve a oportunidade de observar e conhecer a forma como é realizada a assistência na instituição. 
Nessa Maternidade, a inserção inicial foi caracterizada pela boa receptividade pelos profissionais do serviço. O fato de conhecer, pessoalmente, alguns dos profissionais envolvidos na assistência facilitou o início do processo de observação.

No transcorrer do estudo, também foram obedecidas algumas premissas básicas da pesquisa etnográfica, com destaque para a constante preocupação relativa à atitude de estranhamento em relação ao que foi observado; o pressuposto da familiaridade que implica no conhecimento e na intimidade, e é fator que deve ser superado quando se utiliza a ótica da antropologia social, e a questão da totalidade (Magnani 2009; Da Matta, 1993; Morse,1998).

A atitude de estranhamento em relação aos fatos observados foi mantida. Esta atitude permite que o pesquisador não apenas se depare com o significado do arranjo do nativo mas, ao perceber esse significado e conseguindo descrevê-lo nos seus próprios termos, seja capaz de apreender essa lógica e incorporá-la de acordo com os padrões de seu próprio aparato intelectual e até mesmo de seu sistema de valores e percepção (Magnani, 2009).

A característica da totalidade como pressuposto da etnografia diz respeito à dupla face que apresenta, de um lado, a forma como é vivida pelos atores sociais e, de outro, como é percebida e descrita pelo investigador. Assim, totalidade consistente em termos da etnografia é aquela que, experimentada e reconhecida pelos atores sociais, é identificada pelo investigador, podendo ser descrita em termos categoriais. Se para aqueles constitui o contexto da experiência diária, para o segundo pode também se transformar em chave e condição de inteligibilidade (Magnani, 2009).

\subsubsection{As entrevistas etnográficas}

No momento em que a pesquisadora se sentiu familiarizada na comunidade e seus membros demonstraram comportamentos indicativos desta 
familiaridade, foi possível dar início às entrevistas etnográficas, que foram realizadas concomitantemente ao desenvolvimento da observação-participante.

Entrevistar consiste em um processo de dirigir a conversação de forma a colher informação relevante de determinada pessoa (ou pessoas). Na pesquisa etnográfica, a entrevista acontece entre o pesquisador e o informante, de forma interessada e paciente (Angrosino, 2009).

Por outro lado, ao decidir conduzir entrevistas etnográficas, é de utilidade realizar a mesma pergunta a um ou mais informantes, distinguindo em que momento podem ser feitas as perguntas informais e as formais. As primeiras ocorrem durante o processo da observação participante no campo, enquanto as segundas são mantidas com tempo e local marcados para tal fim e conforme uma demanda específica (Angrosino, 2009). No caso do presente estudo, deu-se na busca de respostas dos participantes à temática do estudo - as crenças e os valores dos profissionais que atuam na assistência em um CPN.

Nesta abordagem técnica, pressupõe-se que seja realizada uma entrevista em profundidade, com enfoque no tema sob estudo. O que permite que as pessoas compartilhem suas ideias sobre o cuidado, de forma espontânea com a pesquisadora e, com isto, descobrir, documentar, preservar e interpretar minuciosamente esses significados e essas experiências do dado grupo cultural (Leininger 2006). Nesta pesquisa, isto foi feito mediante gravação integral das entrevistas em áudio.

As questões norteadoras propostas para a entrevista foram as seguintes:

- Fale-me sobre como são as práticas do CPN no seu dia-a-dia

- Fale-me sobre os recursos (cama de parto, banheira, bola, chuveiro, banco para parto de cócoras, etc) disponíveis no CPN e como você os utiliza

- Fale-me a respeito de tudo o que você faz em relação à parturiente, desde o momento em que ela chega ao CPN até o momento em que ela sai deste setor 
Tendo em vista o fato do HMMAA tratar-se de uma instituição que é referência do município para atenção ao parto, a única a dispor de um CPN, além de ser Hospital Amigo da Criança, considerei necessário conhecer as ideias centrais dos mentores do Projeto do Centro de Parto Normal. Os principais profissionais que tiveram envolvimento com o projeto, tanto em suas fases de concepção e implementação, como aqueles que possuem ligação no aspecto administrativo e de elaboração, foram entrevistados. A inclusão destas pessoas teve a finalidade de contextualização social e política, visto a especificidade já mencionada.

Suas narrativas aparecem no início da descrição da Maternidade, com intuito de clarear o cenário de sua inserção social e política e o conteúdo delas não se constituiu em objeto de análise nesta pesquisa. Cada narrativa foi precedida pela apresentação pessoal sumária do colaborador e finalizada com os pontos relevantes das suas narrativas. Os pontos relevantes são itens que evidenciam os pontos chaves da narrativa, servindo como guia para facilitar a compreensão da leitura.

Os entrevistados foram denominados como colaboradores. As entrevistas foram agendadas em comum acordo entre as partes e realizadas em local de escolha dos próprios colaboradores. Todos optaram pelo local de trabalho. Foram realizadas em uma sala de descanso, onde houve total privacidade.

A pesquisadora coletou pessoalmente o conjunto de dados no decorrer do processo de OP. As duas primeiras entrevistas tiveram a presença e o auxílio da orientadora desta pesquisa. As demais foram feitas pela própria pesquisadora, pois esta se sentiu capaz de realizar as seguintes, sem que houvesse algum prejuízo quanto à riqueza e à profundidade dos dados.

Aos colaboradores que tiveram envolvimento no processo de concepção e implementação do Centro de Parto foi solicitado que recuperassem o histórico que culminou com a inauguração do mesmo e seu funcionamento após a inauguração. Nas entrevistas com os colaboradores, que estão no âmbito administrativo, foi solicitado que expusessem o que pensavam e vislumbravam em relação ao futuro da proposta. 
O cerne das entrevistas dos profissionais atuantes no Centro de Parto orientou-se na compreensão dos valores, das crenças e das práticas no trabalho que desenvolviam. Com o intuito de facilitar o início das narrativas, sugeri que as iniciassem falando dos motivos que os levaram a escolher a profissão e, na sequência, como chegaram até a Maternidade Amador Aguiar, especificamente no Centro de Parto Normal. Com base neste recurso introdutório, todos os colaboradores demonstraram facilidade em prosseguir suas narrativas, visto que cada qual deu um rumo próprio e desejado para elas.

À medida que as entrevistas eram feitas foi observado o momento em que se obtinha a saturação da pesquisa. A saturação da pesquisa etnográfica refere-se ao momento em que os dados das narrativas se repetem ou apresentam profundidade. Devido a esse critério foram realizadas, no contexto estudado, dez entrevistas com enfermeiras obstétricas, seis com médicos ginecologistas, seis com médicos neonatologistas, quatro com técnicas de enfermagem, uma com fisioterapeuta e uma com a faxineira. Além das demais entrevistas com a administração.

As entrevistas dos profissionais foram realizadas entre outubro de $2010 \mathrm{e}$ abril de 2011. A duração das entrevistas oscilou entre 15 minutos e 1h. Os nomes verdadeiros dos colaboradores da pesquisa foram substituídos por outros, com a finalidade de preservar a confidencialidade dos dados, para que os depoentes não viessem sofrer prejuízos consequentes à participação nesta pesquisa. A pesquisadora escolheu uma sigla para identificação dos colaboradores da Maternidade.

Os princípios de rigor, entre os quais se pode destacar a adequação dos dados ou saturação da pesquisa; a neutralidade; e a confiabilidade ou consistência do trabalho; basearam-se nos critérios estabelecidos por consagrados estudiosos do método qualitativo. (Denzin, Lincoln 2005; Morse 1998; Patton 1990). Este conjunto de pressupostos embasou o trabalho de campo desta pesquisa. 


\subsubsection{Os informantes-chave e gerais}

Os informantes do estudo foram compostos pelos profissionais envolvidos na assistência ao parto no CPN da Maternidade Amador Aguiar. As entrevistas foram realizadas com os informantes-chave e gerais, respectivamente. São considerados informantes-chave, os profissionais que possuíam grande conhecimento a respeito da cultura estudada. No caso desta pesquisa, os profissionais que estavam há mais tempo no $\mathrm{CPN}$ da Maternidade e/ou participaram da implementação e da estruturação do CPN na instituição. Os informantes gerais são os membros da cultura que possuem conhecimentos genéricos a respeito da cultura (Leininger,2006).

A equipe de profissionais que atuam diretamente na assistência ao parto é composta por enfermeiros, técnicos de enfermagem, médicos obstetras, médicos neonatologistas, mas também está presente uma fisioterapeuta.

\subsection{OS ASPECTOS ÉTICOS E A AUTORIZAÇÃO PARA O DESENVOLVIMENTO DA PESQUISA}

A autorização para realização desta pesquisa foi solicitada ao diretor da Maternidade e à superintendente da Divisão de Enfermagem, que demonstraram interesse e aprovaram a ideia de o CPN da instituição ser alvo de descrição cultural sistematizada.

O projeto foi submetido à apreciação e aprovado pelo Comitê de Ética da Escola (CEP) de Enfermagem da Universidade de São Paulo. A coleta dos dados foi iniciada somente após aprovação do projeto de pesquisa pelo CEP. O termo de aprovação encontra-se no ANEXO 1.

Os aspectos ético-legais foram respeitados de forma a garantir aos participantes os direitos constantes no Termo de Consentimento Livre e Esclarecido (TCLE), segundo a determinação da Resolução 196/1996, do Conselho Nacional de 
Saúde, que trata das Diretrizes e Normas Regulamentadoras de Pesquisas em Seres Humanos (Brasil, 1996). Seu teor encontra-se descrito no APÊNDICE 1.

Foi esclarecido aos participantes da pesquisa sobre a necessidade da gravação e publicação dos dados na comunidade científica em eventos e periódicos nacionais e internacionais.

\subsection{A EXPOSIÇÃO E A ANÁLISE DOS DADOS}

$\mathrm{Na}$ análise qualitativa, em especial na etnográfica, a análise dos dados é complexa. A análise de dados qualitativos envolve o pensar que é consciente, sistemático, organizado e instrumental, portanto a reflexividade está sempre presente. É um processo de interação entre o pesquisador e seus dados (Becker, 1993).

Os dados referentes aos profissionais do CPN foram apresentados por meio da exposição editada de cada narrativa. Os conteúdos das entrevistas foram editados conforme descrito a seguir.

Primeiro foi realizada a transcrição da entrevista. As características individuais de expressão foram preservadas, mas os erros gramaticais foram corrigidos e a sequência da entrevista foi alterada de modo que os assuntos ficassem mais claros de serem percebidos. Os excessos, os abusos de palavras, os "nés", "sabe", entre outros, foram eliminados.

As narrativas foram analisadas com a finalidade de se obter uma visão mais abrangente do conjunto de dados. Um processo contínuo de desenvolvimento de categorias e redução dos dados foi realizado, para compor um modelo manejável, que se constitui na meta final da pesquisa qualitativa. Este modelo permite a reflexão do que realmente acontece no presente contexto cultural. Este trabalho requer grande senso de liberdade, para possibilitar a descrição da realidade de forma fidedigna e, ao mesmo, tempo criativa (Janesick, 1998).

Pequenos trechos extraídos das narrativas foram utilizados para exemplificar conteúdos e significados constantes nas categorias descritivas. Este 
recurso foi utilizado para tornar a descrição da experiência mais próxima da realidade e preservar a perspectiva pessoal dos colaboradores. Isto também permite facilitar a compreensão e aproximar o leitor das práticas cotidianas e das condutas frente as mulheres, os bebês e seus acompanhantes.

Cada trecho está seguido por números, que correspondem aos colaboradores que narraram ter vivido semelhante experiência. A descrição da experiência, de forma mais fidedigna à realidade, é avaliada como relevante na apresentação dos resultados das pesquisas qualitativas (Morse, Swanson, Kuzel, 2001).

Simultaneamente, elaborou-se um esquema conceitual que representa as ideias, as crenças, os valores e as práticas das profissionais atuantes no Centro de Parto Normal estudado. Foram apresentados separadamente os dados referentes aos dados de cada categoria profissional, pelo fato deles terem se apresentado distintos numa leitura preliminar. 
Neste capitulo está descrito o contexto cultural estudado. Primeiramente, são apresentados a Maternidade e o Centro de Parto Normal. A seguir, são expostas as narrativas dos profissionais envolvidos direta ou indiretamente com o projeto do CPN ou que se encontram atualmente envolvidos com a sua administração. No final, estão apresentadas as narrativas das enfermeiras obstétricas, dos técnicos de enfermagem, dos médicos ginecologistas, dos médicos neonatologistas, da fisioterapeuta e da faxineira. Estas narrativas, analisadas separadamente, resultaram nos respectivos esquemas conceituais e subtemas culturais, com seus principais conteúdos exemplificados mediante apresentação de trechos extraídos das narrativas. Dos subtemas culturais emergiu um único tema cultural que sintetiza o cotidiano desta cultura.

$\&$

\subsection{DESCRIÇÃO DO CENÁRIO DO ESTUDO}

O Hospital e Maternidade Municipal Amador Aguiar, focalizado neste estudo, foi inaugurado em 1996 e está localizado no Município de Osasco, Região Metropolitana de São Paulo. Este hospital é referência no município para assistência ao parto no Sistema Único de Saúde, sendo a única instituição da região que possui o título de "Hospital Amigo da Criança", obtido em 2000 e renovado em 2009 pelo Ministério da Saúde e pelo UNICEF. Os índices de mortalidade infantil registrados no hospital estão abaixo do que considerado aceitável pela OMS. É a única unidade pública da região oeste da Grande São Paulo a oferecer o parto humanizado e que presta atendimento em obstetrícia para casos de alto risco; e também a única no país a fazer o exame da orelha, obrigatório por lei, em todos os recém-nascidos. 
Nesta maternidade eram feitos 600 partos por mês, em média, e, desse total, mais de 100 se referiam à assistência ao parto de mulheres moradoras de cidades vizinhas. A maternidade registra alto índice de sucesso nos casos de nascimentos prematuros. Em 2008, foi atingido o menor coeficiente de óbito neonatal dos últimos 3 anos, com 9,3 óbitos a cada mil nascidos vivos.

A maternidade também possui o alojamento mãe-canguru e um ambulatório com especialidades em neonatologia. Todos os $\mathrm{RN}$ nascidos na unidade são submetidos a exames preventivos, dentre eles a triagem auditiva, o teste oftalmológico do reflexo do olho vermelho e a triagem neonatal. A alta hospitalar é dada somente após terem sido imunizados pelas primeiras doses das vacinas BCG e hepatite B. A maternidade dispõe de um ambulatório pediátrico por onde os $\mathrm{RN}$ que nascerem na instituição são examinados uma semana após a alta.

O Centro de Parto Humanizado, que iniciou suas atividades em novembro de 2007, possibilita à parturiente ter ao seu lado um acompanhante de escolha no processo de nascimento e parto. Na sequência, o trinômio é transferido para o alojamento conjunto (AC).

Uma pesquisa realizada em 2009 revelou que a maternidade deste hospital foi avaliada, entre os usuários do SUS, como um dos melhores do Estado de São Paulo. Esta avaliação resultou de um questionário que foi remetido para cerca de 1,5 milhão de usuários que haviam passado por consulta, internação, cirurgia ou exames nos hospitais públicos em todo o território do Estado, entre 2008 e 2009. Além de confirmar as informações sobre os procedimentos médicos pelos quais haviam passado, os usuários avaliaram a qualidade e a agilidade do atendimento dos profissionais e da infraestrutura oferecida.

$\mathrm{Na}$ sequência, os nomes (fictícios) de alguns administradores da maternidade, as características de seus cargos e suas narrativas estão apresentadas. 


\section{Rubens Sérgio - médico ginecologista, foi diretor técnico do Hospital e Maternidade Municipal Amador Aguiar (HMMAA) no momento da inauguração do Centro de Parto Normal (CPN). Trabalha também como chefe de obstetrícia no HSPE-FMO. Está na maternidade há cinco anos.}

“Esta Maternidade foi criada por uma parceria com o Bradesco, através da pessoa do Amador Aguiar, quando era presidente. Através desta parceria, da doação do terreno e da construção, surgiu a Maternidade. Ela foi projetada para atender uma demanda de gestação de baixo-risco, portanto sua missão não era gravidez de risco, em razão disso ela não tem UTI de adultos. A realidade desta maternidade é que ela atende todos os partos do SUS do município. Nos dados do IBGE e do DATASUS, Osasco tem aproximadamente de onze a doze mil partos por ano, esta Maternidade faz aproximadamente seis mil. Se você considerar Osasco uma cidade industrial, no mínimo, metade da população tem convênio médico, a outra metade, que é desassistida e que depende exclusivamente do SUS, tem seus partos aqui. Então, ela é a Maternidade do SUS no Município. Desta forma, ela teve que se adequar a uma demanda de gravidez de risco porque os hospitais que são referência, cuja obrigação é do Estado, não dão o suporte necessário, como em todo sistema de saúde. Então, ela tem uma UTI neonatal que tem uma taxa, invariavelmente acima de 100\%, inclusive ela atende gravidez de risco de outros municípios. Fora isso, uma demanda espontânea que não pode ser recusada. Ela trabalha com comissões atuantes, com auditoria permanente de indicadores, a nossa taxa de mortalidade perinatal é em torno de vinte por mil, um número bom para essa região. Em razão disso, vamos alocando recursos, resolvendo problemas que são necessários para a redução da mortalidade. Historicamente, esses indices tiveram melhora significativa. A Maternidade tem uma concepção de quem atende os partos normais é o enfermeiro ou enfermeira obstetra, em função disso, a equipe é composta por quatro médicos e cinco enfermeiras obstetras em regime de plantão, obviamente isso nunca é completo por faltas, folgas, licenças de funcionários. É um número que é considerado adequado para a demanda de assistência ao parto, mas o número de médicos é pequeno, porque esta maternidade também é referência para os casos ginecológicos de emergência, pois os pronto-socorros não têm ginecologistas, como é uma realidade em todos os municípios. A Maternidade atende cerca de 150 consultas em 24 horas, tem um volume de avaliação de gestação, de rotina de risco de praticamente setenta a oitenta cardiotocografias de porta por dia. Tem um problema de fluxo, porque a gestante entra na fila para ser atendida junto com a demanda espontânea ou referenciada e de casos ginecológicos que também têm que ser atendidos. Nós temos uma luta permanente para adequar esta realidade, seja na cobrança de ginecologistas na rede seja no fato de reposição de corpo clínico. A Maternidade funciona bem, do ponto de vista de indicadores, a taxa de óbitos maternos é baixa, eles são investigados através de uma comissão e encaminhados para comissão de ética, e os óbitos perinatais também são investigados por uma comissão atuante. A série histórica que montei desde quando fui diretor em 2006 tem mostrado decréscimo de mortalidade, na verdade, a taxa de mortalidade de recém-nascido com menos de 1,500g tem uma taxa bem similar aos de peso normal. Temos lutado para a redução de mortalidade 
naquelas faixas de RN de muito baixo peso, isto depende de UTI e, no nosso caso, não depende de equipamentos ou recursos públicos. Nossa taxa é baixa e vem se reduzindo. No nosso caso o problema é a mortalidade pós-neonatal, que ocorre por infecção e por tempo prolongado na UTI. Então, existe necessidade de adequação do número de leitos e de área física para cuidados intermediários. Nosso corpo de enfermagem é muito bom, os enfermeiros que trabalham na assistência ao parto são todos especializados ou legalmente habilitados para executar esta tarefa, muitos deles trabalham há anos nesta maternidade, têm empenho em humanização do parto; e o que orgulha a maternidade é que ela é campo de estágio para enfermagem, tanto para graduação quanto para pós-graduação, particularmente em enfermagem obstétrica. Nossa Maternidade tem os problemas dos serviços públicos, uma dotação de verbas que não é específica da Maternidade, que é ligada a Secretaria da Saúde e que distribui as verbas de acordo com o que coloca como prioridade. Nos dois últimos anos foi construída uma sala multimeios para uso das mães de recém-nascidos que ficam muito tempo na UTI. Temos equipe que dá suporte psicológico específico para esse grupo de mães. Fazemos eventos com mães de RN que sobreviveram e é gratificante. O que procuramos fazer aqui é seguir protocolos da instituição completamente descritos e implantados, para o parto normal sem distócia para os momentos em que o enfermeiro chama o médico, baseado em eventos registrados no protocolo, e para o momento que o médico seja acionado em qualquer situação que o enfermeiro precisar do suporte. Temos alguns problemas com isso, por causa da formação do médico, o que torna dificil com que ele seja parceiro de uma equipe multiprofissional, ele sempre acha que tem o saber maior, isto não é culpa de personalidade e sim do tipo de formação que tem o nosso médico. O segundo ponto de dificuldade é que o médico tem um plantão estafante e caracteriza que é uma gravidez de baixo-risco e encaminha a enfermeira que cuida até o momento que é necessário. Quando é chamado, não gosta, pois, em primeiro lugar, ele vai ter que atuar e em segundo pode achar que está chamando tarde, numa condição de sequela/óbito eminente e ele vai ser responsável por terminar o processo. Isto é difícil de colocar em protocolo, pois depende da vivência de cada um. O que se pode fazer para minimizar isso: discutir na admissão muito isso com ela e em segundo fazer reuniões com a equipe onde complicou ou qual é o momento de chamar. Nossa maternidade tem três áreas de PPP montadas, tem uma área de uma banheira e um pré-parto coletivo separado com cortinas. Os leitos de PPP são pouco utilizados, justamente porque a demanda é muito grande, em função disso o CPN é usado de maneira a atender o trabalho de parto de maneira coletiva; em geral, a experiência com acompanhante é muito bom. Se você parte do princípio de que parto humanizado é um conceito universal, porque eu vou ter sete pacientes num pré-parto comum e três em uma área para parto humanizado. Como vou discriminar ou escolher? Alguns lugares têm uma triagem na admissão, que é feita com critérios técnicos, o que é mais justo. O nosso Centro de Parto é subutilizado, não por falta de recursos, mas por volume de trabalho, limitação de pessoal, às vezes. Uma boa assistência é caracterizada quando a parturiente sente que está num sistema onde tem segurança de encontrar referência no momento que precisar. A segunda coisa é a recepção do hospital. Temos também uma visita para a gestante conhecer o local e boa assistência no momento do parto é ela sentir ambiente acolhedor em todos os sentidos. Os indicadores são bons, mas o conforto não é bom. Antes desta Maternidade abrir, o Secretário me pediu para montar a Maternidade e eu 
perguntei quantos partos por ano a maternidade faria e se teria alto risco e ele me disse que faria 800 partos por ano e não teria alto-risco. E eu falei então acho que a Maternidade tem que ser focada em assistência obstétrica por enfermeira, pois investe-se mais no parto normal, medicaliza menos e ele montou a maternidade com foco na equipe de enfermagem obstétrica. Mas a maternidade depois teve que absorver a demanda do municipio, pois o sistema de referência não funciona. Para mim, foi uma experiência muito boa, conheci pessoas ótimas, esta maternidade tem um alcance extraordinário neste município. O nosso banco de leite arrecada cerca de mil litros de leite e é o único referência para toda essa região, imagina tudo o que temos aqui que não está divulgado. A Maternidade não recebe o carinho que ela merece da Secretaria da Saúde."

\section{Pontos relevantes da narrativa:}

- A maternidade foi projetada para atender uma demanda de gestação de baixorisco, mas teve que se adequar a uma demanda de gravidez de risco.

- Realiza cerca de 150 consultas em 24 horas.

- A taxa de mortalidade perinatal é em torno de vinte por mil.

- A taxa de mortalidade de $\mathrm{RN}$ com menos de $1,500 \mathrm{~g}$ é bem similar à dos de peso normal.

- O banco de leite arrecada cerca de mil litros de leite e é o único referência para a região.

- O Centro de Parto é subutilizado, não por falta de recursos, mas por volume de trabalho e limitação pessoal.

- A assistência é focada na enfermeira obstetra, pois se investe mais no parto normal e medicaliza menos. 
Resultados

\section{Narrativa de Priscila, enfermeira obstetra, responsável atual pela divisão de enfermagem da Maternidade Amador Aguiar (HMAA). Está na maternidade há três anos.}

"Sou enfermeira há 28 anos. Trabalhei durante todo este tempo em UTI de trauma. Depois, trabalhei um período na Secretaria de Saúde até que essa superintendência me convidou para fazer parte da equipe. Estou faz três anos na Maternidade. Realmente, tinha pouco conhecimento da parte específica, já havia feito administração, mas nada específico da obstetrícia. Fui fazer uma pós em obstetrícia que conclui na UNASP, mais a título de conhecimento, ma,s como consequência, me apaixonei pela obstétrica. Não pretendo fazer parto, pois gosto demais do prénatal. Na parte administrativa é sempre novo, estamos sempre aprendendo. Na gerência da enfermagem eu vejo o todo, não só o Centro de Parto Normal;temos a UTI neonatal que ocupa bastante tempo da parte administrativa. Quanto à rotina do CPN, a paciente chega é avaliada no G.O., nosso pronto-socorro, onde se elege o que vai ser feito. A partir deste momento, ela passa a ser assistida pela enfermeira obstetra até o momento de dar à luz, a não ser que ela tenha uma distócia, mas ela fica no pré-parto este período, ela tem direito a acompanhante, que é um facilitador muito grande, pois traz segurança para ela. Os enfermeiros obstetras já têm bastante experiência, o que facilita muito. A média de parto aqui é de 450 a 500 parto/mês, sendo uma média de $70 \%$ dos partos normais. E $60 \%$ desses partos normais acontecem sem nenhuma intervenção médica. O médico só faz a internação e o restante é conduzido pela enfermeira obstetra. Ele pode avaliar, mas não precisa fazer nenhuma intervenção, pois tudo é conduzido pela enfermeira obstetra. Fico muito satisfeita, pois, em termos gráficos, não chega a 1\% os problemas durante um parto normal aqui. Temos vários projetos para serem executados no Centro de Parto. Lá temos uma antessala que foi criada para acontecer o parto natural sem nenhuma intervenção, apenas assistido pelo enfermeiro, mas ainda, pela filosofia de alguns médicos, ainda não aconteceu. No entanto, este ano a superintendência nos apoiou para participarmos da REHUNA, o que indica que estão começando a aceitar. O médico que indica quando é parto natural ou normal, se fosse uma indicação do enfermeiro obstetra já estaria em atividade há algum tempo. Já fizemos alguns partos naturais ali, mas não é uma rotina. Não posso dizer que seja a nossa realidade. Um grande recurso que temos é a nossa UTI neo, que é referência, possui prematuros extremos, com bebês de 550g. É algo muito importante para mãe que chega com parto prematuro em saber que levará seu bebê para casa. Dentro do CPN temos também um atendimento de emergência, na sala 2, caso haja intercorrência o parto é realizado neste local, que é apropriado tanto para mãe quanto para o $R N$. No geral, o relacionamento da equipe aqui é muito bom. Tem um trabalho desenvolvido por uma psicóloga com os funcionários para atender da melhor forma a mãe. Temos instruídos os funcionários para que entendam a situação da mãe. Quando vim trabalhar aqui, o CPN estava funcionando há um ano e meio. Quanto aos protocolos nos outros setores tem, no CPN nós tiramos para atualizar algumas coisas, mas todos têm acesso a eles. Uma boa assistência é deixar a mãe realmente satisfeita, deixando a mãe escolher, dentro do possível, o que ela quer e, claro, com índice de infecção zero. Em relação a minha prática, ainda não estou 
satisfeita, pois acho que ainda tenho muito o que fazer aqui. Pretendo melhorar o quadro de funcionários, dar melhores condições de trabalho, fazendo, por exemplo, uma sala onde pode relaxar do jeito que quiser. Este projeto já está pronto, mas o espaço não foi liberado para mim ainda. Quero deixar uma sala de espera para o acompanhante, onde terá uma TV com vídeos informativos. A minha experiência no Amador foi uma surpresa, mas tenho certeza que contribui, foi uma vivência diferente que me entusiasmou com o trabalho, tem sido insubstituivel".

\section{Pontos relevantes da narrativa:}

- Na Maternidade, 70 \% dos partos são normais;

- Dos partos normais, 60 \% são sem nenhuma intervenção médica;

- O Centro Humanizado não é usado pela resistência de alguns médicos.

- O médico é quem indica quando é parto natural ou normal.

- No CPN os protocolos foram retirados para atualização, mas todos têm acesso a eles.

- Temos vários projetos para serem executados no Centro de Parto.

- Pretendo melhorar o quadro de funcionários e dar melhores condições de trabalho. 


\section{DADOS ESTRUTURAIS E DE ASSISTÊNCIA DO CENTRO DE PARTO NORMAL}

\subsubsection{Descrição estrutural do CPN}

O Centro de Parto Normal do Hospital e Maternidade Municipal Amador Aguiar foi inaugurado em novembro de 2007 com a finalidade de oferecer assistência humanizada e digna ao parto. O local em que foi construído o CPN era um pronto-socorro.

A ala em que o CPN estava localizado possuía um consultório de Ginecologia e Obstetrícia (GO), um posto de enfermagem, uma sala com camas para as mulheres ficarem sob observação e controle, por exemplo, de pressão arterial, e uma sala para realização de cardiotocografia. A ala ao lado é o Centro Obstétrico para atendimento à gestante de médio e alto riscos.

Ao entrar no CPN, do lado direito estão duas suítes de parto humanizado, que continham camas PPP, e mais outra sala de tamanho médio, em que ficavam recursos como cavalinho, bola, bancos para o acompanhante. Na parte de fora das suítes também há uma banheira. Este espaço, porém, foi utilizado poucas vezes e encontra-se fechado. Somente é aberto quando o Alojamento Conjunto está lotado e não há mais lugares, ou quando acontece algum problema no ambulatório de GO.

Depois deste ambiente existe outra sala, do lado direito, que é o conforto de enfermagem. À esquerda ficam armários para que as enfermeiras guardem bolsas e outros pertences. À frente há um banheiro e à direita está um quarto com dois beliches e uma mesa com uma televisão antiga.

Continuando, encontramos, do lado direito, também uma copa-cozinha, onde os funcionários podem preparar suas refeições. Tem um forno de micro-ondas, uma pia, uma geladeira.

No corredor, ao lado esquerdo, tem uma sala de expurgo, um depósito de material de limpeza e, mais à frente, uma sala de recuperação com dois leitos. 
Ao lado direito, o CPN conta também com uma sala de pré-parto com quatro leitos. Os leitos são separados por cortinas e ao lado de cada leito existe uma cadeira para o acompanhante utilizar.

No ambiente do pré-parto existe um posto de enfermagem utilizado pelos técnicos de enfermagem, onde preparam as medicações contidas na prescrição ou as que são solicitadas pelos enfermeiros.

Existe um armário que serve de bancada com um telefone, com o qual se comunicam com administração e alojamento conjunto, e que possui também os demais sistemas de informação necessários. O sonar, quando termina de ser utilizado, também é deixado ali em cima. Na parte inferior do armário estão guardados forros, lençóis e toalhas de banho. Os banheiros estão localizados ao fundo da sala do pré-parto. Um deles possui um chuveiro. Dentro do box do chuveiro fica uma cadeira para que a parturiente possa sentar-se e deixar a água correr sobre suas costas.

Ao fundo do CPN estão dispostas uma área limpa e duas salas de parto. Quanto às salas de parto, uma é composta por uma cama de parto tradicional e a outra por uma cama PPP, que ficava no ambiente das suítes e foi deslocada para uma das salas de parto pelas próprias enfermeiras; conta com berço aquecido, materiais para reanimação e realização do parto, caixa de perfurocortantes, balança.

\subsubsection{A assistência desenvolvida no CPN}

Os profissionais que trabalham no CPN são escalados em regime de plantão. Cada plantão conta teoricamente com cinco enfermeiros obstetras, em regime 24 horas, sendo um dia fixo da semana; cinco técnicos de enfermagem e uma auxiliar de serviços gerais, em regime 12 por 36 horas; cinco médicos obstetras e dois neonatologistas plantonistas em regime de 20 horas semanais.

A seguir, são apresentados os itens que fazem parte do protocolo de encaminhamento de parturientes para o CPN. Nele, está determinado que as parturientes que apresentam as seguintes características devem ser internadas: 
- Acompanhamento pré-natal sem anormalidades, incluindo os resultados dos exames laboratoriais.

- Idade gestacional entre 37 e 41 semanas completas.

- Altura uterina menor ou igual a 36 centímetros.

- Feto único em apresentação cefálica fletida.

- Líquido amniótico claro à amnioscopia.

- Exame cardiotocográfico com resultado dentro da normalidade.

- Bolsa íntegra ou rota até 4 horas.

- Colo uterino esvaecido e com dilatação maior ou igual a 3 centímetros.

- Dinâmica uterina: duas a três contrações regulares em 10 minutos.

$\mathrm{O}$ atendimento à parturiente é prestado de acordo com o fluxo assistencial, conforme apresentado na Figura 3.

Figura 3 - $\quad$ Fluxo Assistencial do Centro de Parto Normal.

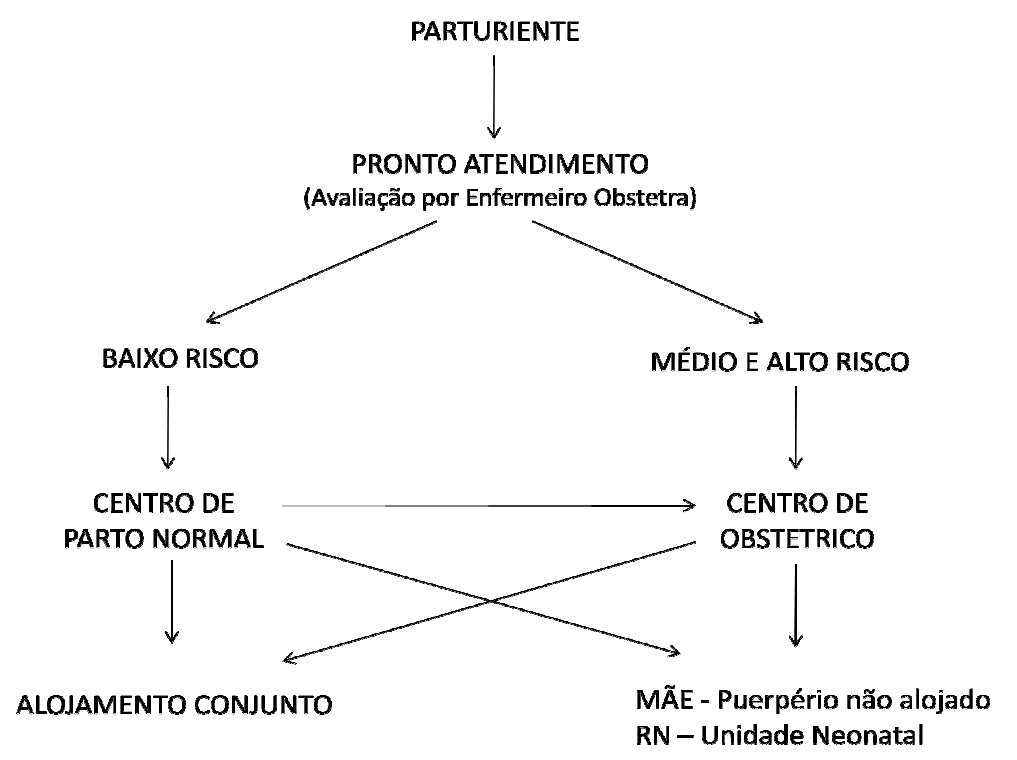

Fonte: Protocolo de atendimento do HMMAA

As atribuições destes profissionais e suas atividades na assistência ao parto são descritas de forma reduzida a seguir. São apresentadas as atividades constantes no Protocolo Institucional (PI) seguidas das observações derivadas do processo de Observação Participante (OP). 


\section{CONSULTÓRIO DE GINECOLOGIA E OBSTETRÍCIA}

PI: Médico Obstetra: A assistência à mulher inicia com avaliação e diagnóstico de trabalho de parto (TP) e internação da gestante. Se for diagnosticada alguma patologia obstétrica a gestante é encaminhada para o Centro Cirúrgico. Pode encaminhar a gestante para verificar a vitalidade fetal por meio da cardiotocografia (CTB), que depois avalia e toma as condutas.

Enfermeiro Obstetra: O CTB era realizado pelos enfermeiros obstetras do CPN em uma sala que fica externa à unidade do Centro de Parto.

OP: - Constatei que muitas mulheres com patologias obstétricas eram encaminhadas pelo obstetra para o Centro de Parto Normal por falta de vagas na unidade de patologias.

- Muitas vezes os critérios constantes no protocolo de encaminhamento para o CPN não eram seguidos e as mulheres eram internadas fora de trabalho de parto.

- Percebi que era árduo para as enfermeiras ficarem no cardiotoco pela demanda de serviço dentro do CPN.

\section{ASSISTÊNCIA NO CPN}

\section{Recepção}

PI: Técnico ou enfermeiro: O profissional deve apresentar-se nominalmente e profissionalmente à parturiente e ao acompanhante, como também apresentar o leito em que ela e seu acompanhante ficariam acomodados. Neste momento inicial também devem orientá-la em relação a: dieta geral, deambulação, realização de banho de asperção ou imersão quando quiser ou for estimulada, realização de exercícios como balanço pélvico ou "cavalinho" e bola, sempre que quiser ou for estimulada, manter repouso no leito em Decúbito Lateral Esquerdo (DLE), quando quisesse permanecer deitada.

OP: - Esta apresentação inicial ainda era muito falha, bem como as informações que eram prestadas às parturientes, pois muitos profissionais não se identificavam à parturiente e ao seu acompanhante, realizando apenas os procedimentos técnicos necessários. 
- Os acompanhantes ficavam um pouco desorientados no CPN e, para se situarem, andavam bastante pelo ambiente, o que promoviava outro problema porque os leitos eram separados por cortinas que facilmente podiam estar abertas. Desta forma, a outra gestante ficava exposta ao acompanhante de sua vizinha de leito.

\section{Admissão}

PI: Enfermeiro Obstetra: Realiza a admissão por meio de preenchimento da ficha de admissão (anamnese e coleta dos dados), exame físico geral e obstétrico, evolução, prescrição de enfermagem, pelo reforço das orientações anteriores, e da abertura do partograma se estiver na fase ativa. Coleta de sangue para exames laboratoriais de rotina ou que for solicitado. Se necessário, prescreve: Ocitocina $5 \mathrm{U}$ SG5\% $500 \mathrm{ml}$, iniciando com 8 gotas por minuto.

Técnico de enfermagem: Registra a admissão da parturiente no livro de registro, controla os sinais vitais, realiza anotações de enfermagem, dependendo do estágio do trabalho de parto a encaminha para o banho, oferecendo toalha e camisola. Os sinais vitais são controlados a cada seis horas, mas se há necessidade de intervalo menor, a enfermeira ou o médico solicitam via prescrição.

OP: - Percebi que era muito raro toalhas no CPN, então sempre oferecem lençóis para que as mulheres se enxuguem.

- Quanto a abrir e finalizar o partograma, com linha de alerta e ação para as mulheres com verdadeiro trabalho de parto (fase ativa), muitos profissionais possuem dificuldades de preenchê-lo de forma completa e correta. Observei que muitos enfermeiros preenchem apenas a primeira e a segunda horas de TP.

\section{Condução e indução do trabalho de parto}

PI: Enfermeiro Obstetra: A condução do TP acontece avaliando as especificidades de cada parturiente, por exemplo, induzir o parto ou realizar a amniotomia. No caso de dúvida quanto ao aspecto do líquido amniótico realiza-se a amnioscopia. A indução do TP é feita com a indicação e a condução com ocitócito deve ser feita somente nos casos que já foram tentados todos os métodos alternativos e sempre que houver condução com ocitócito o mesmo deve ser colocado em bomba de infusão. $\mathrm{Na}$ condução no trabalho de parto o enfermeiro obstetra deve fazer controle do TP rigoroso e orientar a mulher e o acompanhante. Se diagnosticam possíveis distócias e alteração do quadro clínico materno-fetal, solicitam a avaliação do médico obstetra. 
Os enfermeiros obstetras, em conformidade, fazem o controle dos batimentos cardíacos fetais (bcf) em média de 1/1 hora e o toque vaginal (avaliação da dilatação do colo uterino) de $2 / 2$ horas no mínimo, verificam os padrões das contrações uterinas (Dinâmica Uterina - DU) de 1/1 hora ou de acordo com a necessidade.

OP: - As orientações do TP não acontece de forma efetiva.

- Os ocitócitos são instalados em grande parte na chegada da gestante no CPN sem ao menos ter qualquer estímulo aos métodos alternativos, sendo um número reduzido colocado em bomba de infusão. Observei mulheres desligando o soro, sem que os profissionais percebessem, para amenizar suas contrações.

\section{Métodos não farmacológicos}

PI: Enfermeiro Obstetra: Quanto à prescrição interativa de medidas de conforto, como deambulação, respiração, banho de asperção ou imersão, exercícios de balanço pélvico e exercícios em bola suíça.

OP: - As condutas orientadas dependem do enfermeiro obstetra que está prestando a assistência. Existem aqueles enfermeiros que usam de todos esses recursos disponíveis, menos do banho de imersão porque a banheira está desativada, e até interagem o acompanhante e os ensinam a fazer massagens na cervical e lombar da parturiente, de fato, estes são minoria, e existem enfermeiros que raramente encaminham para o banho ou deambulação e nunca utilizam-se dos outros recursos.

\section{Assistência ao parto}

PI: Enfermeiro Obstetra identifica o período expulsivo, informa a parturiente e seu acompanhante sobre o momento do nascimento, a parturiente é conduzida até a sala de parto. Segundo o protocolo, a parturiente deveria permanecer na posição de maior conforto pra ela. O enfermeiro obstetra procede à lavagem das mãos e se paramenta, solicita que informem o neonatologista, coloca o campo estéril sobre a mulher e realiza a antissepsia.

OP: - Em uma das salas de parto a cama só permitia a realização do parto em posição litotômica e na outra sala algumas enfermeiras conseguiram trazer uma das camas de parto do Centro Humanizado. Assim um número reduzido de enfermeiras realizava o parto nesta cama PPP com a mulher em posição semi-sentada ou lateralizada. 


\section{Episiotomia e manobra de Kristeller}

PI: Enfermeiro Obstetra: A realização de episiotomia deve ser feita apenas com indicação, manobra de Kristeller é proibida.

Técnico de enfermagem: auxilia o neonatologista nos procedimentos. Realiza a pesagem do $\mathrm{RN}$, auxilia o enfermeiro obstetra durante o procedimento de Episiorrafia (se houver), na abertura de seus materiais ou para limpar a puérpera.

OP: - Em 70\% dos nascimentos que acompanhei foi realizada a episiotomia, comparei com o número presente nos prontuários e realmente está era a média de episiotomias. Presenciei poucas vezes a "Manobra de Kristeller" que estava inclusive terminantemente proibida de ser realizada no $\mathrm{CPN}$, existia até um informe no corredor do lado da sala de parto referente à sua proibição.

\section{Cuidados ao RN: Contato precoce mãe-filho}

PI: Enfermeiro Obstetra: Na recepção do RN observam os batimentos cardíacos, tonicidade muscular e choro. Após o clampeamento do cordão umbilical, deve-se oferecer a tesoura para o acompanhante para que este corte o cordão umbilical, se esta for a sua vontade. Deve-se colocar o RN em contato pele-a pele com a mãe.

Médico Neonatologista: está presente em todo o nascimento, ele observa sinais clínicos de vitalidade do RN através do choro e freqüência cardíaca, observa e acompanha o RN saudável no contato pele a pele com a mãe, quando este é feito. $\mathrm{O}$ tempo para este contato deveria ser de aproximadamente 15 minutos.

OP: - Esta prática tem sido mais freqüente entre os enfermeiros mas não o era. A administração realizou reuniões com toda a equipe para que fosse realizada em todos os nascimentos, porque este era um passo que estava pendente para obtenção do título de Hospital Amigo da Criança, assim como também o clampeamento tardio do cordão umbilical. Observei duas vezes apenas ser proposto ao acompanhante para que cortasse o cordão. Quando era feito o contato pele a pele os neonatologistas esperavam no máximo 5 minutos.

\section{Procedimentos com RN: Aspiração vias aéreas e gástrica}

PI: Médico Neonatologista: Encaminha o RN para o berço aquecido, onde realiza o exame físico, limpa o cordão umbilical com álcool a 70\%, pinga o nitrato de prata a $1 \%$ nos olhos do RN. A aspiração das vias aéreas superiores e a aspiração gástrica 
devem ser evitadas, Assim como o oxigênio inalatório só deve ser administrado se houver necessidade e é um procedimento que pode ser realizado em cima da mãe. OP: - Em todos os nascimentos esses procedimentos eram realizados. O uso de oxigênio inalatório era menos freqüente sendo sempre realizado no berço aquecido.

\section{Pós-parto}

PI: Enfermeiro Obstetra: faz a prescrição de enfermagem

Técnico de enfermagem: Encaminha o RN para a mãe e estimula a amamentação na primeira meia hora de vida, orienta medidas de higiene e cuidados com o períneo.

OP: - As mulheres ficavam no corredor no pós-parto. Existiam dias que o corredor ficava cheio. Elas ficavam em macas muito estreitas com o RN e às vezes não tinham ninguém por perto, o que tornava muito fácil a queda do $\mathrm{RN}$ da maca. Existiam dias que ficam muitas horas esperando por vagas no AC. 


\subsection{AS ENFERMEIRAS OBSTÉTRICAS, SUAS CARACTERÍSTICAS, SUAS NARRATIVAS, O ESQUEMA CONCEITUAL E O SUBTEMA CULTURAL}

As principais características dos informantes-chave e gerais estão apresentadas, de forma sintética, no quadro 1, que contém a idade em anos, o estado civil, a paridade e o tipo de parto, o maior grau de escolaridade, o ano do término da graduação, o tempo que está na instituição HMAA e o número de empregos que possuem. Todos estes dados foram fornecidos no momento da entrevista.

Quadro 1 - $\quad$ Enfermeiras obstétricas e suas características. São Paulo, 2011

\begin{tabular}{|c|c|c|c|c|c|c|c|c|c|}
\hline Entrevista & Idade & Naturalidade & Religião & Estado Civil & Paridade & $\begin{array}{c}\text { Maior Grau } \\
\text { Escolaridade }\end{array}$ & $\begin{array}{c}\text { Tempo de } \\
\text { experiência } \\
\text { profissional } \\
\text { na área } \\
\end{array}$ & $\begin{array}{c}\text { Tempo na } \\
\text { Instituição }\end{array}$ & $\begin{array}{c}\mathrm{N} \text { de } \\
\text { Empregos }\end{array}$ \\
\hline \multicolumn{10}{|c|}{ INFORMANTES-CHAVE } \\
\hline EO1 & 46 & Paraíba & Católica & Casada & 2 & Especialização & 1989 & 10 anos & 2 \\
\hline $\mathrm{EO} 2$ & 46 & Paraíba & Espírita & Divorciada & 1 & Especialização & 1997 & 6 anos & 2 \\
\hline EO3 & 45 & $\begin{array}{c}\text { Rio Grande do } \\
\text { Sul }\end{array}$ & Católica & Divorciada & 3 & Mestrado & 1985 & 7 anos & 3 \\
\hline \multicolumn{10}{|c|}{ INFORMANTES GERAIS } \\
\hline EO4 & 67 & São Paulo & Evangélica & Casada & 3 & Especialização & 1974 & 14 anos & 2 \\
\hline EO5 & 51 & Bahia & Espírita & Casada & 1 & Especialização & 1990 & 2 anos & 2 \\
\hline EO6 & 44 & São Paulo & Evangélica & Casada & 1 & Especialização & 2001 & 5 anos & 2 \\
\hline EO7 & 51 & Chilena & Católica & Casada & 3 & Especialização & 2005 & 1 ano & 2 \\
\hline EO8 & 42 & São Paulo & Católica & Casada & 2 & Especialização & 1995 & 7 anos & 2 \\
\hline EO9 & 47 & São Paulo & Evangélica & Casada & 2 & Mestrado & 1986 & 3 anos & 3 \\
\hline EO10 & 60 & São Paulo & Católica & Casada & 2 & Especialização & 1977 & 4 anos & 2 \\
\hline
\end{tabular}

Nesta pesquisa, observa-se que as 10 enfermeiras obstetras que colaboraram tinham entre 42 e 67 anos, com média de 54 anos; cinco delas eram naturais de São Paulo, duas da Paraíba, uma do Rio Grande do Sul e uma da Bahia. A média de paridade era de dois filhos. Oito eram casadas e duas divorciadas. Com relação ao maior grau de escolaridade, oito das enfermeiras tinham especialização em obstetrícia e duas tinham mestrado. Quanto à religião, cinco declararam ser católicas, três eram evangélicas e duas espíritas. Quanto ao ano de término da graduação, o período foi de 1974 a 2005. Quanto ao tempo na instituição, variou de 1 a 10 anos, com média de 6 anos. A média de empregos das enfermeiras obstétricas foi de 2 empregos. 


\section{As Suas Narrativas}

EO 1: "Fiz enfermagem pela Universidade Federal da Paraíba e conclui em 1989. Somente exerci a profissão em 1997, não tinha terminado a pós mas fazia parto na minha cidade, como curiosa. Neste ano vim para São Paulo fazer a pós-graduação em obstetrícia. Era só com isso que me identificava na enfermagem. Fiz na Uniban a pós e fui trabalhar fazendo parto na prefeitura de Itapecerica da Serra, meu primeiro emprego. Fazia 6 ou 7 anos que não fazia nenhum parto, fiz com a ajuda de outras colegas. Fui embora novamente para a Paraíba, mas vi que o que queria estava aqui. Pedi a uma amiga para avisar quando houvesse algum concurso. Surgiu o concurso de Osasco. Passei e fui chamada. Deixei tudo na Paraíba, um emprego de doze anos de funcionária pública, que pedi exoneração. A inauguração desta Maternidade foi em 1996 mas estou desde aqui desde maio de 2000. Na época não existia o parto humanizado. Era o setor de Centro Cirúrgico e CO junto; onde é o CPN hoje era um pronto-socorro, o volume era muito grande, em torno de mil partos por mês. Trabalhava 40 horas, plantão 12 por 36. Entrei também num serviço particular, fazendo parto. Deve fazer três ou quatro anos que virou Centro de Parto Normal e que não somos mais responsáveis pelo Centro Cirúrgico. O que mudou aqui muito: a resistência muito grande para acompanhante. Eu mesma não queria porque achava que ficando perto interferiria e a paciente ficaria manhosa. Mudei completamente de opinião. Vi que é ótimo porque o acompanhante vê como a paciente é tratada, tenho o respaldo dele quanto a minha conduta. É positivo para a paciente ter um acompanhante para se sentir mais segura. Tem alguém da sua família, não um desconhecido. Noventa e nove por cento dos acompanhantes ajudam, pois incentivam a cliente a cooperar. Humanizou muito para a cliente, mas nós mesmos fomos humanizados com a presença dos acompanhantes. O que mudou também foram os exercícios, que antes não fazíamos na paciente, não colocávamos na bola, cavalinho, andava muito pouco, a paciente era mantida deitada. Tudo foi mudado depois do movimento do parto natural e depois da existência do CPN. Infelizmente temos uma parte inteira do Centro de Parto que fica inutilizada. Acredito que a falta de funcionários prejudica, pois nem sempre tem funcionário para deixar nos dois ambientes. São duas suites de parto separadas das demais camas do pré-parto, que é sempre cheio. Quero deixar a cliente, mas quem vai cuidar? Com um número maior de funcionários, talvez desse certo ou se não fosse tão longe. A planta física prejudica. A banheira não é utilizada. Ela não tem suporte de apoio, é estreita, uma paciente obesa terá dificuldade. Ali tudo foi uma coisa política. Houve uma grande inauguração, mas o que mudou no Amador Aguiar desde quando entrei foi: hoje tem um acompanhante. Talvez não seja "O Centro de Parto Natural” como realmente não é, mas temos os exercícios e acompanhante para ficar durante o trabalho de parto e na sala de parto. No entanto, a banheira, ter um quarto só, ter privacidade não existe, porque apesar de ter cortina, você escuta o outro falando. Não é como deveria ser. Em outros Centros de Parto são suites separadas, não se vê e nem se escuta quem está do outro lado. Quando mudou de Centro Cirúrgico para Centro de Parto Normal foi falado do acompanhante e exercício, mas não me lembro de nenhuma palestra. Quanto às colegas da obstetrícia, nos damos muito bem. Tem uma amiga que faz dez anos que trabalhamos juntos. Com a equipe de técnico e auxiliares de enfermagem, como é um hospital público, muita gente é concursada e tem muita falta. São cinco enfermeiras obstétricas 
por plantão de 24 horas, das 8 hàs 8 hs, com dia fixo. Os auxiliares são doze por trinta e seis, mas no dia a dia não temos problemas com eles, porque são muito sacrificados também por falta de funcionários. A equipe médica de dia são quatro e a noite teoricamente quatro, mas geralmente tem três. Não temos problemas com a equipe médica, às vezes tem um ou outro que não quer aceitar sua opinião, mas a maioria aceita, nem todos são experientes, mas há muito respeito. Tem só uma doutora durante o dia que é difícil é o jeito dela não adianta ficar brigando. Eles só veem ao CPN quando solicitados ou no final do plantão. Tem as fisioterapeutas que veem fazer estágio é ótimo. Elas andam com a paciente, orientam, fazem massagem, põem na bola. Funciona bem o trabalho da fisioterapia. Gosto, pois as pacientes se sentem mais acolhidas. Como aqui é um Centro de Parto Normal as pacientes teriam que ser internadas em trabalho de parto, mas isso não acontece. Pode ser pela insegurança do médico, por comodidade ou a família vem várias vezes e o médico acaba internando. Tem paciente com um centímetro, colo grosso, que interna. A indicação é pós-data, mas não deve vir para o CPN, é paciente de enfermaria. A paciente é avaliada no G.O., se encaminhada para o CPN tem contato com o auxiliar e depois com a enfermeira que admite a paciente. Se ela não tiver cardiotoco nós fazemos e conduzimos o trabalho de parto com indução com ocitocina ou misoprostol. O misoprostol é de enfermaria, mas quando não tem enfermeira lá, o médico manda pra. Brigamos porque não é uma paciente de CPN. É uma paciente que está no lugar de outra, mas fica por questão administrativa. Tudo depende do médico da porta. Se for seguro manda a paciente para casa, porque pelo protocolo daqui você espera até quarenta e uma semanas. Mas a médica de hoje interna para tudo. Semana passada tinha um monte de pacientes aqui fora de trabalho de parto. Temos autonomia, só chamamos o médico se tiver alguma intercorrência. Usamos a bola para fazer exercício, para ajudar na dilatação e descida do bebê, tem as massagens no cóccix que, quando tem acompanhante, explicamos e ele faz, tem o cavalinho que colocamos para ajudar na dilatação e o banho, além de estimular a paciente para andar. A grande maioria das pacientes aceita bem tudo, mas algumas não ficam na bola, por exemplo, porque dói demais e então orientamos, não podemos obrigar, dizemos a ela que se ficar assim em vez de nascer com 6 horas vai nascer com doze horas, mas é uma decisão sua. As primigestas ajudam muito mais e as multíparas muito menos, parece que quando já se sabe o processo fica pior. Outra paciente que dá trabalho também é uma paciente com cesárea anterior, ela já vem com a ideia que teve uma cesárea e quer outra. É igual a paciente que grita, grita, grita, distocio, aí você leva, a outra que está quietinha já pensa: "Ela gritou e vai para cesárea. Eu vou gritar também”. Sempre falo se você quer gritar é um direito seu, mas também é um direito meu não ficar aqui para ouvir. Vou te ajudar, te examinar, mas ficar do teu lado ouvindo você gritar não sou obrigada. Falo também que não adianta gritar, porque primeiro a dor não vai passar, você não vai mandar oxigênio para o seu bebê e quanto mais você ficar desta forma mais o parto vai ser demorado. Claro que vai ter umas 'tigronas', já levei pesada. Levar uma pesada quando você não tem nada a ver com isso, você não tem nada ver que a pessoa está grávida. Você está ali para ajudar. Quando essas coisas acontecem eu chamo o médico porque eu tenho que ter o respaldo dele. Às vezes a presença do médico tranquiliza, pois acham que tudo que diz está certo. Na hora do parto geralmente a gente muda a paciente para outra sala ou a gente faz o parto no leito quando é uma paciente multipara. Neste Centro de Parto Normal existe uma cama que vira cama de parto, 
justamente para não tirar a paciente de lugar, mas nós tiramos e depois levamos para sala de parto. Eu nunca deixo o acompanhante ficar olhando bem a vulva porque acho que ele não está ali para isso. Ele deve acompanhá-la e dar apoio a ela. O parto humanizado preconiza deixar o bebê em cima da mãe, demorar para cortar o cordão, parar o batimento. Mas o volume aqui é muito grande, não dá tempo de fazer tudo isso. Quando dá, nós fazemos. Depois de cortar o cordão, entregamos o bebê para o neo que examina. Em seguida, quando termina a sutura, o bebê é deixado na sala para mamar, mas por pouco tempo. Se necessário, fazemos o teste rápido, sendo negativo, pode mamar. A mãe fica duas horas ou mais depois do parto até ser liberado o quarto, quando não tem vaga ficam muitas horas. Estando tudo bem, examino e libero para o quarto. A prescrição do pós-parto é feita por nós porque tem o protocolo. A partir do momento que o partograma é aberto, deixamos de evoluir para anotar no partograma, se houve alguma intercorrência é anotado nele qual foi. Nem todos os enfermeiros fazem episiotomia, depende do períneo. É avaliado na hora se é necessário. Tem uma colega que faz muito parto lateral, nunca fiz parto lateral, mas quanto a Episio já se vê no préparto os períneos bem resistentes, fibrosados. Por fim, dou um piquizinho, mas não tem que tudo tem que ser Episio. Amo muito o que faço, se não fizesse isso não faria outra coisa. Fico satisfeita quando consigo passar tranquilidade para a paciente. Como a rotatividade é muito grande, às vezes você fica longe da paciente. No outro hospital que trabalho é melhor porque sou a única referência delas e isto gera proximidade. É diferente daqui, que não se consegue fazer muito vínculo, pois examino mas tenho que sair e fazer CTB. Quando dá tudo certo é a melhor coisa, não digo pensando em agradecimento. Fazendo meu trabalho bem feito e todos ficando felizes já foi um bom plantão. É claro que quando a paciente agradece para o seu ego é maravilhoso. Quer dizer, você fica satisfeita, você trabalha com vida. É desgastante, mas é muito gratificante. Esta é a diferença de um médico para uma enfermeira, claro que existem as exceções, se por no lugar da paciente. Um dia pensei em fazer Medicina antes de ser Enfermeira, mas hoje agradeço porque acho que seria igual eles. Acho que contamina. Meu trabalho nestes anos todos só tem muita coisa boa, se aconteceu algo ruim é porque o médico não nos escuta. Mas eu gosto muito do que faço, não conseguiria fazer outra coisa e graças a Deus nesses anos que trabalho poucas coisas deram errado. Se a gente faz o que a gente gosta com amor e com responsabilidade dá tudo certo." 
Resultados

EO 2: "Era enfermeira generalista no Leonor, trabalhava no Alojamento Conjunto e Centro Obstétrico, quando surgiu a oportunidade para as enfermeiras do estado, principalmente as que trabalhavam em Alojamento Conjunto, se especializarem na obstetrícia direto com a assistência ao binômio. Depois de uma avaliação, o José Serra financiou um curso de obstetrícia na USP. Eu já gostava muito de trabalhar com o binômio, sempre tive paixão. Então conclui o curso na USP e continuei no Leonor. Fiz estágio no Hospital de Taipas e fiz pré-natal no Amparo Maternal. Gostei muito do pré-natal, talvez, se tivesse tido oportunidade, teria ficado lá, mas a oportunidade surgiu em sala de parto. Me colocaram no Leonor no CO definitivo. Fiquei mais ou menos uns dez meses me preparando para um novo emprego porque lá a oportunidade não era boa, o CPN não havia aberto ainda. Terminados os dez meses surgiu oportunidade no Hospital Metropolitano, na Lapa, e me colocaram como supervisora do Alojamento Conjunto. Estava frustrada porque não era o que queria. Tinha feito várias provas em Itapecerica e Itapevi. Em Itapevi surgiu um serviço novo, fiz a prova teórica e passei numa boa classificação. Fiquei lá três anos e três meses quando surgiu o concurso de Osasco para enfermeira obstetra. Faltava muito material no início, o fluxo de trabalho no Amador sempre foi imenso. Cheguei a fazer sozinha 15 partos em 24 horas. De repente, abriram vários hospitais na região, o que dividiu esta quantidade de partos. Eram 1.100 a 1.200 partos por mês, passou a ter 500 partos, ficou mais tranquilo. Tentei me adaptar, mesmo com as dificuldades. No Leonor sou supervisora geral do noturno e aqui faço os partos que gosto. No Amador trabalhamos com quatro médicos obstetras no periodo diurno e quatro noturno. A paciente dá entrada, faz a ficha no pronto-atendimento, passa pelo médico que está na porta de plantão. Esse médico direciona a paciente para fazer somente o exame de cardiotoco ou internar em trabalho de parto. Ao ser internada, fazemos todo o serviço de acordo com as condições de trabalho. Se for uma paciente patológica, encaminhamos ao setor de gestante de alto risco ou AC 3. O trabalho da enfermeira obstetra é assim: a paciente interna, entra para o pré-parto, é feita sua admissão, são levantados todos os exames de pré-natal, se necessário fazemos o teste rápido, conduzimos todo o trabalho de parto até a segunda hora após o nascimento. Quando tem alguma intercorrência, temos que ter condições de fazer o diagnóstico clínico, obstétrico. Se deixa de ser um parto sem distócia para um parto com distócia, chamamos o médico para avaliar. Então, o médico dá continuidade. Temos que ter condições de diagnosticar para entregar o feto em boas condições para o médico realizar uma cesárea, caso necessário. A equipe médica daqui não tem prática em fórceps, assim, quando chega um transverso que não evolui para um OP, é feita a cesárea. Somo responsáveis só pelo o trabalho de parto de termo, a partir de 37 semanas e sem distócia. Mas, se chegar paciente DHEG ou com bebê soropositivo, temos condições de fazer todo um Kit de tratamento. As primigestas sempre levo para a sala de parto com acompanhante presente, se precisar de Episio, faço uma muito pequena, tudo o que você orienta a primigesta há sucesso, já a multípara é o contrário, acha que já sabe fazer e não colabora. Minha experiência com acompanhante é boa, poucos não colaboram porque veem embriagados. Mas, na maioria, acabam auxiliando e sua presença é importante, pois vê seu esforço e trabalho o que oferece realmente a mulher. Muitos já me ajudaram até em situações dificeis, quando a paciente esperneia. Então, é uma experiência positiva. Sempre que posso, minhas pacientes vão 
para o banho com cinco ou seis centímetros, peço para o acompanhante fazer massagem com vaselina no cóccix durante a contração até o seu término, por uma hora. Isso ajuda muito na interação. Uso também a bola para o movimento de quadril. A banheira não uso porque as suites estão desativas. O que mais me incomoda no plantão são as internações feitas fora de trabalho de parto. Trabalhamos em equipe junto com a equipe médica, com o neonatologista, com fisioterapeuta. Esta questão das internações a equipe médica deixa a desejar. Na verdade aqui não é caracterizado um Centro de Parto Normal, porque não temos um protocolo de CPN e também as pacientes patológicas são internadas juntamente com as não patológicas. Tenho experiência em outro Centro de Parto Normal, mas aqui não consigo desenvolver porque foram montadas suites de parto no mesmo andar, mas estão desativadas. Existe uma banheira, um espaço, bola, banquinho, mas por alguns motivos, talvez políticos, da instituição, não desenvolvemos um serviço de parto normal. Foram feitas tentativas com camas PPP, mas as camas não foram aprovadas, pois não são adequadas, para usá-las é necessário ajoelhar no chão para fazer o parto. O CPN tem que ter um protocolo e seguir à risca, além de ter todos os profissionais com o mesmo tipo de orientação e o mesmo tipo de assistência. Existe um protocolo geral de trabalho, um protocolo de atendimento de entrada, internação, transferência, algumas patologias junto, mas não há um protocolo específico à parturiente e de um Centro de Parto Normal. O que é um protocolo de Centro de Parto Normal: a paciente interna em franco trabalho de parto com cinco centímetros de dilatação, uma bolsa íntegra ou no mínimo rota há 24 horas, estrepto negativo, acima de 37 semanas até 41 semanas, uma altura uterina até $35 \mathrm{~cm}$, Episio o mínimo possível, acompanhante sempre, presença de alimentação, direito a um retorno pela enfermeira obstetra. Desta forma, o CPN tem um protocolo fixo, no qual qualquer atua igual, mesmo num grupo de 35 enfermeiras obstétricas, que tem o seu jeito. Aqui não tem um protocolo por causa da política da instituição, porque depende de alguém que tenha força política e conhecimento. Assim, no serviço em geral você acompanha a politica da instituição, a política do município. Nós já tivemos muitas supervisoras e cada hora que muda vai dificultando. Cada plantão faz o que acha melhor, uns prezam para a Episio outros menos, uns acham que o acompanhante atrapalha, outras trabalham com a massagem. Temos pessoas formadas com diversas filosofias $e$ cada um faz do seu jeito. No meu plantão fazemos da forma que a consciência, junto com o conhecimento, direciona. Então, temos que tentar fazer da melhor forma possível. O que me deixa satisfeita é saber que todos os bebês nasceram bem, acho que a coisa mais triste é perder um bebê. Sempre agradeço por nunca ter perdido. Quanto à valorização profissional em si a remuneração é baixa, a carga horária é longa, o trabalho é pesado”. 
EO 3: "Sou enfermeira obstetra há 25 anos. Sempre atuei na área, ou no setor de patologia obstétrica ou no próprio parto na maternidade. Hoje sou docente também. Sempre gostei de parto humanizado, só que a visão que nós tínhamos a 25 anos atrás era diferente de hoje em dia. $O$ primeiro parto que deixei nascer na maca quase não me formo em obstetrícia, porque era obrigatório episiotomia em todos os partos. A assistência era voltada para os procedimentos e intervenções. Hoje, graças a Deus, parto humanizado é aquele em que a parturiente é protagonista do seu parto. Ela participa do jeito que achar melhor, dentro das possibilidades, da fisiologia normal, sem distócia nenhuma, então ela escolhe o tipo de parto, o que quer fazer e como, se deseja andar, sentar, comer; tem direito ao acompanhante. Tudo isso são valores que fazem muito bem ao parto. $O$ trabalho que faço é com amor, porque dinheiro nenhum paga. Então, desde a graduação, quando passei em obstetrícia, eu já sabia que ia ser obstetriz, fiz e não saí mais. Estou no Amador Aguiar há seis anos. Cheguei aqui da seguinte forma: já lecionava na universidade, mas sempre fui assistencial. Não conseguia ficar longe da assistência, então quando soube do concurso, prestei. Quando entrei, não tinha nada, nem se pensava em ter o parto humanizado, era pré-parto, alto risco e baixo risco, e nós enfermeiros controlávamos os partos de baixo risco. Até que veio a solicitação da Secretaria em se formar o Centro de Parto Normal com a atuação do enfermeiro obstetra. Como já trabalhei em Centro de Parto Normal no Hospital São Mateus e no Santa Marcelina, e tinha a experiência, fui convidada para planejar como seria este CPN. Então nós associamos rotinas das outras unidades, muitas coisas. Era para ser perfeito aqui. Só que tudo que fizemos foi encaminhado para a nossa coordenadora, coordenadora para a Secretaria. Só que politicamente não veio nada do que era pra ter feito. Por exemplo, nós temos uma banheira que supostamente seria chamada de hidromassagem, que é enganação porque nem de água enche, mas no dia da inauguração foi aquela festa, fotografia, mas nada funcionando. As camas de PPP antigas... Começou por aí. Depois veio a parte de funcionários que não fizeram treinamento. Não nos adequaram a um Centro de Parto Normal. Resumindo, o nosso verdadeiro Centro de Parto Normal que era para existir, fechou. Nós continuamos aqui deste outro lado, que é um pré-parto separado por cortinas e uma poltrona do lado. O acompanhante está presente, mas não é o Centro de Parto Normal que deveria ser. Falta muito. Nós temos enfermeiras obstetras suficientes e qualificadíssimas para dar a assistência, mas o espaço físico e a demanda não nos deixam fazer isso, porque nós temos 600 partos por mês: normais. Eu e as colegas damos o melhor da gente, mas podia ser melhor ainda se a instituição ajudasse. Hoje é diferente da outra sexta-feira: está um caos porque tem patologia obstétrica. Resolveram que só vai ter patologia obstétrica no Centro de Parto Normal. Isto porque temos protocolos e toda uma regulamentação para atuarmos. Os profissionais não têm acesso a esses protocolos. Antigamente, ficavam aqui no conforto dos enfermeiros, com acesso livre. Esses protocolos eu e outra enfermeira que montamos, trouxemos dos outros CPN que funcionam plenamente, que é o São Mateus, o Santa Marcelina, o Hospital da Vila Alpina. Tínhamos uma pasta preta com todos os protocolos, só que sumiu. Esse Centro de Parto era para funcionar, mas politicamente, por algum processo que houve, não deu certo. Quanto â trajetória da paciente, a triagem é o médico quem faz, então todo o trabalho de parto interna aqui no pré-parto, a partir do momento que os médicos indicam cesárea, vai para o 
Centro Cirúrgico. Se não indicou cesárea, independente de ser de alto, médio ou baixo riscos, vem pra cá. Sabemos, perante o COREN, que prematuridade nós não faríamos o parto, mas se interna aqui, nós controlamos. Tomamos condutas no CPN quando é de baixo risco, temos nossa autonomia: tirar ou por soro, mandar para o banho, caminhar, bola. Todos esses recursos tínhamos bem no início, agora tem bola furada. Aquele cavalinho é antiguíssimo, hoje em dia tem uns cavalinhos modernos, redondos, para poder fazer o movimento do períneo. Tudo que foi comprado aqui foi com economia. A equipe médica, no meu plantão, passa no pré-parto para averiguar o andamento. A equipe de enfermagem, a equipe médica e neonatologista interagem. Fazemos interação mãe e filho nos partos. Meus partos são no escuro, as luzes são apagadas, principalmente a do foco na hora que o nenê nasce. Se o neo quiser que acenda a luz ele acende. Faço um pouco do que vivencio em outra unidade e o que sabemos que é melhor para a mãe e o bebê. Colocamos no peito para amamentar, o pai pode cortar o cordão umbilical, secar o bebê. Depois que nasce, se houver episiotomia, vamos suturar. Em seguida, a mãe é colocada na maca e espera duas horas para ir para o AC. Neste tempo, vamos prescrever e liberar a mãe, através de um exame sumário, para ver se está tudo bem com ela e no aleitamento. Uma boa assistência, no meu parecer profissional, é aquela em que a mãe se sente livre para falar e fazer o que quiser, durante o parto, que é dela. É um evento dela, quem sou eu para acabar com a felicidade. Lógico que se você deixa a mãe à vontade, e ela confia em você, tudo tende a ir tranquilo. Então, se a mãe quer gritar e não está interferindo na assistência, deixa gritar. Qual o problema? Se ela quer que eu grite junto é capaz de eu gritar junto. Então, a boa assistência é deixar a mãe livre para decidir o que quer, nós somos participantes, mas ela é a protagonista. Me sinto satisfeita em todos os dias. Eu amo o que eu faço. Eu não sinto isso aqui trabalho porque gosto muito. O Amador Aguiar, de onde moro, é uma hora e meia de carro. Pego trânsito, mas venho feliz. Dou o melhor de mim em termos de assistência, de conhecimento, de participação no parto. A minha experiência é ser feliz, gosto muito daqui, sou uma pessoa feliz. Sou a parteira da família, já veio mãe, filha, nora, ganhar comigo. Elas me reconhecem muito mais do que eu a elas "oh parteira, você está aqui, eu trouxe a minha filha”. Dinheiro nenhum paga a realização. Lógico que muitas coisas aqui têm que ser mudadas ou que eram para ter sido feitas desde o início corretamente. Mas o que quero falar é que amo o que eu faço”. 
EO 4: "Terminei o colegial e queria fazer Serviço Social. Passei no vestibular, mas na última hora resolvi fazer enfermagem. Já tinha trabalhado anos antes dentro de um hospital com serviços gerais, então sabia como era a enfermeira. Fiz enfermagem porque era uma das profissões da época que tinha o salário melhor. Decidi, depois, fazer Direito para ser juíza, porque era o que realmente queria ser. Fiz a pós em obstetrícia na Escola Paulista, no Hospital São Paulo. Antes de terminar fui trabalhar no Hospital das Clínicas e fiquei cinco anos, depois no Hospital Municipal da Vergueiro e trabalhei quinze anos. Na área obstétrica fiquei dez anos, dentro do Centro Obstétrico. Depois fui para o ambulatório, pela comodidade de horário. Passava visita na ginecologia, no pré-natal e outras clínicas. Até que a Erundina abriu um concurso, passei e tive que sair daquele hospital porque era autarquia. Então, eu fui para um posto de saúde, trabalhei cinco anos com grupo de gestantes, enfim, aposentei. Antes de aposentar, uma colega falou que o Amador Aguiar estava precisando de funcionários. Poucos dias depois, me convidaram para trabalhar aqui, já me encaixaram para fazer os partos, regime 12 por 36, como contratada CLT do INSS. Depois de oito anos que estava aqui, fiz concurso e me efetivei. A nossa carga horária, que era 40 horas, passou a ser 20 horas. Entramos na escala de um dia só na semana. Começamos aqui o parto humanizado, quase ninguém teve treinamento, então é um parto humanizado que não é. A família fica junto, mas as medicações, a ocitocina nós usamos. Tentamos fazer da maneira certa, mas, por exemplo, a pouco tempo veio um dos diretores aqui no momento em que estava fazendo o parto e disse "faça uma Episio bem aberta. Bem grande”, porque tinham alguns bebês nascendo com fratura de clavícula e eles achavam que era porque não fazia Episio. Parto Humanizado tentamos não fazer Episio, mas uns fazem, outros não. Usamos alguns recursos, como a bola, o chuveiro, massagem, caminhada, ensinamos a família que está junto. Aquelas suites de Parto teoricamente foram inauguradas, mas usamos poucos dias e foi desativada. Aparentemente, porque parece que está com problema. A equipe também se queixava das camas que não eram próprias para isso, muito baixas, a cama não subia e foi muita criticada. Quando fizeram a compra disto tudo ninguém chamou algum conhecedor do parto humanizado. Eu, por exemplo, pego o nenê ali embaixo, mas para suturar não consigo. Quando a gestante chega ela entra no consultório, os médicos examinam, geralmente pedem uma cardiotografia. Nós fazemos o cardiotoco e elas são dispensadas para casa ou vão para a ala de patológicas ou aqui para dentro. No início do trabalho de parto são conduzidas para cá e os parentes são comunicados para fazer a admissão, levam os pertences. Aqui são checados os sinais vitais $e$ administrado soro, que geralmente tem na prescrição. As pacientes chegam aqui geralmente assustadas,isso é natural. Elas são orientadas quanto ao trabalho de parto, apesar de que, quando chegam as contrações verdadeiras, para muitas delas tudo o que você passou de nada adianta, a respiração os exercícios, pedem a cesárea. Mas explicamos de novo e na hora do expulsivo conduzimos, andando, até a mesa ou fazemos na cama se não dá tempo. Tenho muita paciência, explico, falo. Aqui nós precisamos de alguém que incentive o parto humanizado, tinha que instruir todo mundo, porque o parto humanizado é muito gostoso. Acho que devia ter uma atenção melhor para isso, porque quem determina não somos nós. Tinha que orientar os médicos. Uma boa assistência, para mim, é observar direito os sinais do trabalho de parto, ter paciência, dar atenção às 
necessidades desta gestante em trabalho de parto, porque a dor é algo diferente para muitas delas e mesmo aquelas que já passaram por isso chegam no momento das contrações fortes e perdem o controle. Tem que orientar. Qualquer coisa que faço na vida para alguém, fico satisfeita. Me sinto melhor do que quem recebeu. Às vezes passo o plantão no pré-parto, acompanhando, e não faço o parto, é estressante. Quando você faz o parto e diz meu trabalho está concluido, ai é gostoso. Quando temos paciência, explicamos, mantemos a calma é gostoso também. A minha experiência é o seguinte: gosto de trabalhar aqui, gosto de fazer parto, gosto do serviço. Como eu disse no início: a minha intenção era fazer Direito, mas gosto do que faço". 
EO 5: "Fiz minha graduação na Bahia, tive uma professora na área de maternoinfantil que era enfermeira obstetra e me identifiquei com a área por causa dela. Quando terminei a graduação, há 22 anos, vim para São Paulo porque só aqui e no Rio tinha especialização em obstetrícia. Trabalhei no berçário no Santa Marcelina enquanto fazia a pós. Terminei e vim trabalhar direto no C.O. tradicional, lá aprendi com as colegas antigas em obstetrícia. Neste periodo também fiz voluntariado no Amparo Maternal, onde tive minha primeira experiência com a humanização. Tive convite para trabalhar nas duas casas de parto que surgiram em São Paulo, no Sapopemba e na Casa de Maria; trabalhei no São Mateus e no Leonor faz seis anos que estou lá no CPN. Algumas colegas do Leonor que indicaram o processo seletivo daqui, do esquema de plantão de 24 horas, que existia um CPN. Fiz a seleção e passei. Aqui é muito bom para trabalhar, as colegas são boas, mas falta humanização. Aqui é diferente de outros lugares, por exemplo, tem gestantes patológicas no CPN, mas tentamos fazer o possivel. Porém, não dá pra dar uma assistência muito humanizada porque tem mulheres em começo de trabalho de parto. Você é obrigada a instalar ocitocina e conduzir. O que a gente pode fazer a gente faz. Nem todas as colegas trabalharam antes com o modelo humanizado e isso se torna um pouco difícil. Nasci de parto normal domiciliar com parteira, então, para mim, o parto normal é a melhor coisa do mundo. Quando criança, esperava do lado de fora enquanto minha mãe dava à luz. Para mim, é algo bom, todos ficavam contentes. Minha criação foi diferente, não tinha aquele terror do parto, o parto do meu filho foi normal. Então, sei como é e por isso posso compartilhar com as mulheres para que tenham outra visão do parto normal. Aqui nós temos que induzir, o que faz a mulher se cansar, gastar mais energia, porque ficou muito tempo internada. Sei que aos poucos chegamos ao modelo ideal. A mulher aqui é admitida pelo G.O., não é como em casa de parto ou no próprio Leonor, que as próprias enfermeiras fazem a admissão e já têm o contato antecipado com a mãe. Aqui é diferente: vem da G.O. Explico à mulher como é o atendimento no $C P N$, que pode tomar banho, pode comer, que vai investir no parto normal, mas se for necessário, é feita a cesárea. Vou explicando o porquê do soro, porque a bolsa rompeu, que a bola é boa para exercicios para ajudar o bebê a descer, o banho de relaxamento, que ajuda o colo a esvaecer e suportar mais a dor e no parto coloco o bebê na mãe para ter contato pele a pele sempre que possivel, porque às vezes o neonatologista fica do seu lado, apressando. Converso sobre aleitamento, cuidados com o coto umbilical; depois, faço o parto e vou explicando, tento fazer lateralizado se elas quiserem. Na mesa de parto não tem como mudar de posição, na cama já dá pra ser de cócoras. Existe uma área do CPN que não é utilizada; já a bola, o banquinho, o chuveiro, a banheira, são. Não é utilizada por causa da distância. A estrutura não é legal, ficou muito distante, mas isso é porque fazem as coisas e não procuram a opinião de quem atua. Uma boa assistência é fazer com que a cliente se sinta bem. Humanizar, para mim, é respeitar a escolha da mulher dentro do possivel. Sempre saio satisfeita. porque fiz aqui o que deveria. Minha consciencia está tranqüila e eu faço o que gosto. Minha experiência é boa, porque sempre aprendo mais". 
EO 6: "Comecei a atuar na obstetrícia há mais ou menos cinco anos. O interesse surgiu devido ao contato no Hospital Santa Marcelina, onde trabalhava, que segue a linha de parto humanizado. Fiz minha pós-graduação neste hospital. Depois da pós, permaneci cinco anos no Hospital de Sapopemba, com o início do Centro de Parto. A obstetrícia é uma área maravilhosa e encantadora para quem gosta de conduzir a assistência. No Amador Aguiar, quando cheguei, só existia o C.O., quem estava na época na administração viu a necessidade de abrir este Centro de Parto, numa linha de parto humanizado e realmente foi uma luta para abri-lo, porque houve resistência da equipe, como um todo, até dos auxiliares, por não querer ficar direto na assistência no CPN, além de também questões políticas. Hoje, através dos esclarecimentos acerca dos benefícios que existem para ambas as partes, está melhor. Existe uma liderança, estamos ganhando o título de Amigo da Criança novamente. Existem resistências, mas tentamos levar na esportiva. Já falei para o Neo assim: olha doutor, deixa com a mãe, então não é amigo da criança é inimigo da criança. Deixa ele com a mãe. Assim os neos sabem que neste plantão existe essa conscientização, então se diz: tá bom, não vou nem chegar perto. Tem tido grandes progressos de alguns anos pra cá, mas esperamos mais. No momento da transição de C.O. para CPN não houve treinamento, o que favoreceu é que muitas de nós que trabalhamos aqui viemos de uma linha de Centro de Parto Humanizado, mas essa humanização é necessária da classe médica, que não está adaptada, preferem fazer uma cesárea e não ter problemas futuramente, do que precisar saber se vai evoluir ou não. A médica deste plantão, quando avalia, pergunta nossa opinião: temos um bom relacionamento. Tentamos acertar também a questão da ocitocina que vem com prescrição médica da porta, pois sabemos que não deve ser administrada para todas, mas infelizmente poucos médicos têm essa visão. Quanto às técnicas, depois de alguns cursos que foram feitos e a partir do convivio conosco, hoje já trabalham como em um Centro de Parto. Se tiver que usar, nós usamos só quando está em franco trabalho de parto. Quanto ao parto, tentamos passar o máximo de segurança para a paciente, estar acompanhando. Além da questão cultural de quebrar paradigmas, porque o brasileiro realmente não está acostumado com parto normal. A maioria quer parto cesárea, então o papel é mostrar as vantagens e as desvantagens de ambos os partos para ela. No pré-natal, é possível fazer isso, porém falta informação, há uma carência no pré-natal. No momento que você é leiga, não sabe o que vai acontecer com você, existe um medo real, então nós tentamos esclarecer, tentamos agilizar o trabalho de parto mostrando alternativas tanto no controle da dor, tanto para diminuir todo esse processo que é extenso. $O$ primeiro contato que a mulher tem é com o médico, quando passa no consultório, depois vem para a gente e rodamos o cardiotoco. Antes dela dar entrada, o médico reavalia esse cardiotoco. Chegando aqui a gente conduz. Muitos dos casos nós vemos se há necessidade de ocitocina ou não. Se vejo necessidade de romper bolsa ou tocar pelo protocolo tenho liberdade de fazer isso. No momento, tento usar também métodos alternativos de controle da dor, banho terapêutico, a bola e temos a cama da sala de parto que conseguimos trazer com muita luta da parte do CPN que está fechada, porque ninguém abre o Centro de Parto. Eu faria o parto lá, com certeza. A banheira, dizem que precisa modificar para cumprir umas exigências, mas talvez não possa ser usada por falta de dinheiro, então. $\mathrm{Na}$ época, o que ouvíamos é que não era muito de interesse da administração, existia muita 
resistência dos médicos em não querer o Centro de Parto. Mas houve muitas mudanças na aceitação e talvez fosse possível reabri-lo novamente. Precisamos rever algumas coisas quanto à estrutura realmente, a banheira precisa de barras de segurança, por exemplo. Nós trouxemos os partos nessa cama, mas não são todos que usam. Eu e mais alguns enfermeiros durante o parto não usamos o foco para não ser agressivo para o bebê e à noite eu apago a luz e deixo apenas um foco para condução, depois faço interação entre mãe e filho; deixo por volta de 20 a 30 minutos, se ela quer ficar com o bebê. O pós-parto também é complicado, porque não tem um lugar adequado para a mãe ficar, então ficam na maca no corredor e ficam duas horas, não sou a favor, mas nós fazemos algumas coisas porque são preconizadas pela instituição. A humanização melhorou bastante da parte dos enfermeiros obstetras, da equipe, da forma como tratam as pacientes respeitando suas necessidades $e$ desejos, tanto para se alimentar, caminhar, quanto ao soro. Uma boa assistência é você ficar muito presente, ficar ao lado, ela ser muito bem assistida. A mãe é que faz o trabalho de expulsão do bebêe nós só amparamos. Então, nesse momento, é importante ter alguém do lado dela. Nós perguntamos quando estão sozinhas e elas falam: o meu marido está lá fora, acho que ele não sabe que pode entrar. Então deixamos ciente de que pode entrar, se for alguém que passará segurança a ela, mas se desejar somente a equipe ela dará o apoio necessário. O importante é ter alguém do lado dela, seja um membro querido seja a própria equipe. Quando realmente dá tudo certo, quando estou conduzindo o parto, eu me sinto satisfeita. Quando o parto acontece de uma forma adequada e todos estão bem. O Amador é um lugar muito rico, onde tem muitos partos, tem dia com 17 partos, sempre se aprende. Aqui não se ganha em termos de salário, mas em termos de satisfação. É um lugar bom para trabalhar". 
EO 7: "Quando tinha quatorze anos minha madrinha, que era matrona no Chile, me convidou para assistir a um parto. Soube que era isso que queria para minha vida, mas no momento relacionei com Medicina Ginecologia-Obstetrícia. Tentei fazer medicina três vezes, mas não passei. Meu pai sugeriu que fizesse Engenharia, fiz dois anos e meio, parei e vim para o Brasil de férias e, por fim, permaneci aqui. Com 40 anos, fiz enfermagem e me especializei na Saúde Pública, em qualidade de Vida da Mulher no Climatério e no outro ano fiz na UNASP obstetrícia. A idade que tinha e a falta de experiência dificultavam para arrumar emprego. Fiz um período de voluntariado nas Clínicas para aperfeiçoamento e por causa disso consegui pontuação para entrar na Prefeitura de Osasco no Posto de Saúde. Trabalhei na Secretaria e em outro Hospital na parte de acolhimento, mas não estava contente. Mandei meu currículo para o Amador Aguiar por intermédio de uma doutora que conheci e em dez dias estava trabalhando aqui. Estou há um ano e vejo que falta interação da equipe multidisciplinar. Tive muitos problemas com médicos, pois muitos são arrogantes e não estão em harmonia, cumprindo protocolos. Então, faço aqui a minha parte. Faço parto humanizado e tento fazer 100\%, mesmo faltando equipamentos, estrutura, uma liderança, uma boa administração. Nossa equipe de domingo é muito boa. Os médicos neonatologistas são ótimos. Como já disse, tive alguns problemas com médicos G.O, pra achar um médico bom é difícil. Na admissão, o G.O. avalia o histórico da mulher, examina e define se é parto cesárea ou normal. Se for normal, nós recebemos, fazemos o histórico dela, outro exame de toque, para conferir os dados, e explicamos o que realmente acontece, com olhar especial para a cultura de cada família. Nós contamos com duas salas de parto e incentivamos que o acompanhante, o pai, participe do momento do nascimento. Quando está com dilatação total e o DeLee de acordo, levamos para a sala. Às vezes, num expulsivo de quarta/quinta gesta, fazemos na cama mesmo, geralmente não tem Episio. No momento de levar para a sala chamamos o neo, tem a circular que fica junto e para qualquer eventualidade pedimos o socorro do médico. No pós-parto ela fica duas horas no mínimo no corredor e as enfermeiras dão continuidade no AC 1. Nossa equipe trabalha com humanização: leva para o chuveiro, para a bola, conversa, se realmente ela tem uma dinâmica muito forte a ocitocina é suspendida. Temos só dois cavalinhos, uma bola e um chuveiro. Então, não temos mais chuveiros para colocar as mulheres, a condição podia ser melhor. A boa assistência se define dando apoio 100\% à mulher; Para dar uma boa assistência, tenho que estar ao lado e ter uma boa comunicação, interagindo e transmitindo confiança, sendo também transparente, contando o que realmente está acontecendo com ela. Fico satisfeita quando o bebê nasce, no sorriso da mãe, ela já agradece com os olhos. Minha experiência aqui tem sido muito dificil, por falta de apoio médico, falta de equipamento, você tem que se virar em 500. O Hospital podia ter uma estrutura maior, mas, por problema político, não tem. No entanto, foi um grande aprendizado. Estou feliz por ter contribuido aqui”. 
EO 8: "Trabalho aqui há sete anos, me formei em 1995 e fui trabalhar em uma grande maternidade. Era enfermeira do Alojamento Conjunto. Trabalhava com amamentação, com o puerpério imediato, a partir daquele momento me despertei para a área de obstetrícia e gostei muito. O parto não tinha nada de humanizado, era um Hospital Escola muito grande, não existia a enfermeira obstetra. Fiquei neste hospital quatro anos. Então, fiz minha pós-graduação em $2000 \mathrm{em}$ obstetricia. Terminando a obstetrícia fiz este concurso e estou há sete anos neste hospital. Gosto muito, acho que foi uma escola para mim. Existem profissionais excelentes. Foi montado um CPN (Centro de Parto Normal), mas infelizmente fecharam. Nossa banheira não está funcionando. Os recursos que temos é um banheiro onde proporcionamos o banho terapêtico para elas, a bola e o cavalinho. Então, na medida do possivel, a gente faz tudo o que pode para proporcionar um momento mais tranquilo para esta paciente. Mas falta muito para ser aquele sonho de não usar nenhum método, nenhuma ocitocina. Isto é muito dificil porque a demanda aqui é muito grande. Muitos médicos internam aqui com dois centímetros, três centímetros. Então, como você vai trabalhar com uma paciente que está com dois centímetros e a demanda na porta é muito grande. Uma paciente com dois centímetros, temos que manter o tempo todo na vigilância, assistindo, no banho, na caminhada e aqui nem espaço temos para isso. A equipe médica, em sua maioria, interna já com ocitocina e nós sabemos que não é o ideal. Mas, enfim, fazemos o melhor para proporcionar o momento mais tranquilo. Falta a atuação da equipe multidisciplinar, a visão dos médicos que é muito importante, não só a da obstetriz, a terapeuta em si, enfim, todos colaborarem. Falta muita coisa, falta união, não é uma andorinha só que faz verão. Não são só as obstetrizes. Eles têm que participar também. Precisam ter noção que estão na porta. E são eles que controlam a entrada. Então, tem que saber o momento correto para poder internar esta paciente. No nosso plantão a equipe médica está trocando muito. Quando entrei tinha uma equipe com os mesmos médicos, mas acabou se dispersando. Eles precisam saber o que acontece dentro do CPN com as obstetrizes. Vão internando, internando e não estão lá para saber o que está acontecendo. Nós avaliamos os cardiotocos e temos que pedir para eles virem avaliar. Se não pedirmos nem sabem como está o plantão. Essa visão tem que mudar. Já ouvi muito aqui dos médicos "humanização, para mim, é cesárea, porque já estamos no século vinte e um e não tem que sentir dor". Isto não tem que ser assim: corta e pronto. Acho que quando você é admitido nesse hospital precisa saber o que as obstetrizes fazem aqui. Quanto à humanização, tem que humanizar já no pré-natal. Tem mães que não sabem nem amamentar, não sabe que dói tanto. Por isso, é importante a participação do anestesista, porque no momento correto, na peridural, orienta esta paciente, porque muitas no pré-natal não foram orientadas em hipótese alguma e quando chega aqui se desesperam. Então, nós explicamos o momento, porque que dói, o que está acontecendo. Isso tinha que ser trabalhado na rede e com os familiares também. No CPN nós montamos uns boxes e os familiares podem entrar e participar. Isso é bom, mas eles também tem que participar do pré-natal, não é só no momento de ver o parto, porque alguns veem só por curiosidade. O acompanhante tem que dar força para ela, que saiba o que fazer no momento do desespero. Alguns participam, outros só querem assistir, tirar foto no momento da expulsão do bebe e não é assim, tem que preservar a mãe. Quando a paciente é admitida pela equipe do plantão, primeiro fazem um 
cardiotoco e avaliam se precisa internar. Na verdade, deveria ter um tanto de dilatação para internar esta paciente, mas internam por bolsa rota, que pode ser internada, mas em outro local, não levar direto para o CPN. Ou mandar aqui para cá com um ou dois centímetros. Na prescrição já está escrito ocitocina oito gotas por minuto, a obstetriz acaba colocando em bomba de infusão. Para romper bolsa tem todo um critério, só rompemos depois dos seis ou sete centímetros. Rodamos o cardiotoco o tempo todo, de seis em seis horas. Orientamos ela caminhar, incentivamos o banho no momento certo, cavalinho, bola. O parto fazemos na posição padrão ginecológica, mas fiz vários partos lateralizados. Fazemos episiotomia só quando realmente for necessário, nas primigestas é raro não fazer Episio, e todo tempo fico explicando pra ela "olha vamos dar uma anestesia local pra fazer um cortinho para o bebe sair", vamos explicando o que ocorre no TP. No puerpério imediato ela fica duas horas conosco, vemos como está a involução uterina, o sangramento, orientamos da amamentação e os auxiliares, depois de duas horas, levam para o AC. Depois, não temos mais contato com a paciente. O nosso CPN está bonito por fora, mas por dentro está um pão embolorado. Eles inauguraram o CPN, aquilo tudo, mas... Acho que só mudou o ambiente, porque é o mesmo trabalho que as obstetrizes faziam antes. A única mudança que teve são os acompanhantes e sem nenhum preparo. Os cuidados em si não mudaram. A planta fisica que mudou. Podia reabrir o CPN, nossa banheira ser liberada, a demanda não ser tão grande, haver internações corretamente, arrumar o estacionamento, colocar mais árvores e bancos para as mulheres caminharem com os familiares quando estiverem com quatro centímetros. Espaço tem para isso, mas falta todos falarem a mesma língua. Uma boa assistência é você orientar, tratar a paciente bem e se colocar no lugar dela. Tentar preservá-la, explicar tudo o que está acontecendo, tirar as suas dúvidas, mostrar que você está entendendo o que ela está pedindo, respeitar. Humanizar é respeitar. Então, amenizar e ficar um pouquinho do lado dela, mostrar que você sabe o quanto dói, mas é um momento feliz que ela tem que passar, porque o bebê dela está chegando. Me sinto satisfeita quando dá tudo certo: os nenês nasceram bem, o apgar maravilhoso, mãe feliz, sem complicação no seu parto. Isso é gratificante para nós. Nada paga você ouvir da mãe: "foi tranquilo, você orientou bem, olha não tive problema”. A minha experiência aqui foi maravilhosa, só não aprende quem não quer, tem colegas que têm grande conhecimento para passar para você. Aqui é uma escola, minha experiência foi muito boa. Financeiramente, aqui não é gratificante, mas te gratifica como profissional. Nada paga e gosto muito daqui". 
EO 9: "Fiz faculdade de enfermagem na UNICID, sou da turma de 1986. No segundo ano de graduação me apaixonei pela obstetrícia, fiz a pós-graduação e desde então nunca parei de trabalhar. Leciono em várias universidades. Antes de entrar nessa instituição era professora da UNIP, depois participei de um processo seletivo e passei. A equipe da segunda-feira que trabalho são todas obstetrizes com mais de 15 anos de formadas, que têm grande compromisso com assistência obstétrica, independente de ser parto via vaginal ou parto cesárea. Os colegas são antigos, temos a mesma fala, condutas, cumplicidade e confiança muito grande. Depois de um ano de convivência com os médicos, eles passaram a ter confiança na nossa equipe, porque até então eles nunca tinham trabalhado com obstetrizes. Há uma cumplicidade muito grande porque os plantonistas confiam no nosso trabalho, pode ser que não seja a realidade de outras equipes. Depende muito da postura e do comportamento da enfermeira obstetra, que, quanto mais mostrar conhecimento e se colocar no lugar de enfermeira obstetra, mais será respeitada. Enquanto você se colocar no lugar de médica não vai ser respeitada, porque você não é. Existe e sempre existiu esse conflito do médico com a enfermeira obstetra, desde o início da História da Obstetrícia. A equipe que trabalho é coesa, trabalhamos realmente em equipe e é o que falta na nossa profissão, está muito longe da equipe de enfermagem se unir, que é o oposto da parte médica, os médicos são corporativistas, eles vêem o que os outros fazem e silenciam, o enfermeiro vê e divulga, o que é um comportamento antiético, e não acontece no nosso plantão, pois tentamos trabalhar com total retidão, partindo dos nossos princípios éticos, morais e religiosos, para que tenhamos sucesso. Aqui trabalhamos com o parto humanizado de uma forma não $100 \%$ humanizado. Humanizado para muitos é um parto sem soroterapia, sem tricotomia, o marido junto e a paciente se alimentando, mas aqui a humanização, para nós, vem dos profissionais, da minha equipe da segunda-feira. As funcionárias participam, até as da limpeza, ajudam a caminhar com a paciente e se ela estiver com dor tem 'partoterapia'. As auxiliares e técnicas participam de uma forma bem efetiva para o sucesso do parto. Não para o sucesso do parto vaginal, para muitos profissionais, principalmente os novos, acham que parto humanizado é deixar a paciente 12, 16, 48 horas no sofrimento para nascer normal. Isso tem que mudar urgente. Não adianta você fazer a paciente ficar 14 a 20 horas em trabalho de parto, no qual todas as reservavas psicológicas e hemodinâmicas acabaram e ter um feto que vai participar da AACD pelo resto da vida. O Ministério da Saúde diz que devemos aumentar a taxa de parto normal, mas não diz que devemos aumentar a taxa de PC de criança com paralisia cerebral. Nesses anos de profissão, nunca tive nenhum problema técnico ou jurídico com relação à assistência que prestei. Vemos muitos casos assim, mas no nosso plantão atuamos até certo limite, quando o parto está se tornando distócito e a linha de ação começa a ser solicitada, é o momento que chamamos o profissional médico. O parto humanizado é feito da seguinte forma: a paciente chega de 4 centímetros, abrimos o partograma, começa a trajetória de banho, apoio psicológico, orientamos a paciente o que pode fazer e o que realmente é o trabalho de parto, quais são as etapas. Se a paciente quer fazer o parto no leito, nós fazemos. Tentamos seguir o protocolo do Ministério da Saúde e contamos com a vivência de 20 ou 30 anos de profissão. É iniciada a condução do trabalho de parto e muitas vezes ela fica na indução com misoprostrol lá no AC3, onde ficam as pacientes que ainda não estão no trabalho de parto, depois vêem para cá em 
franco trabalho de parto. Dificuldades, temos muitas, porque nós temos uma conduta e o médico quer outra, mas acho que com respeito você acaba chegando em um objetivo comum, que é assistência à paciente, porque o filho é dela, a esposa é do marido e não é nossa, nós só somos os condutores dessa história. Quanto a recursos, nós temos a bola, a banheira, só que não usamos, temos cavalinho, fazemos caminhada com as pacientes, antes tínhamos a fisioterapeuta também que participava. Então, dentro do que a instituição pode nos oferecer e o que é preconizado, tentamos usar os recursos. Uma das coisas que vejo que tem muito sucesso é a hidroterapia. A mulher esquece daquele ambiente hostil, porque o banheiro é um ambiente íntimo, só fica quem você ama, e os resultado são muitos bons. A sala que utilizamos atualmente é improvisada, porque o CPN é essa ao lado, mas precisa mudar a cama, que é muito baixa, o banquinho é inadequado. Isso foi talvez inexperiência de quem comprou o material e não perguntou para toda equipe, mas mesmo, assim, 80\% dos partos aqui são normais e em termos de iatrogenia 1\% mais ou menos. No puerpério imediato o binômio fica cerca de 2 horas aqui conosco, o Greemberg. Depois ela vai para o Alojamento Conjunto e qualquer intercorrência lá tem algumas enfermeiras obstetras que atuam, mas na maioria das vezes elas chamam o obstetra para ver algum sangramento ou intercorrência. Uma boa assistência é quando há trabalho em equipe e conhecimento técnico, porque a habilidade técnica é o fundamental para ter o sucesso no trabalho. E sempre, a cada dia que passa temos, que renovar o conhecimento. Volto a dizer, para o sucesso do parto humanizado a equipe multiprofissional tem que se conscientizar desde a equipe até a parturiente. Aqui, trabalho há 3 anos, de profissão vou para 26 anos, e tem sido um período apaixonante, venho aqui porque gosto, gosto de fazer parto, partejar, do contato com a gestante, porque ela é muito carente, adoto todas como minhas filhas, ajo como se fossem minhas filhas e torno uma leoa diante da defesa delas. Gosto muito do que faço aqui, em todos os lugares que atuei o comportamento sempre foi o mesmo, como diz o nosso código de ética, tenho que defendê-las até mesmo dos médicos se sinto que vão fazer alguma coisa errada, tenho que alertá-lo ou deixar que ele assuma completamente a paciente. Sempre saio daqui feliz, querendo voltar, porque gosto do que faço, desde minha formação acadêmica sempre quis obstetrícia e me sinto realizada". 
EO 10: "Fiz enfermagem obstétrica porque está no meu sangue. Minha avó paterna era parteira curiosa. Toda a família do meu pai nasceu nas mãos da minha avó. Quando ela morreu, esqueci. Só depois que o tempo passou e me vi fazendo enfermagem que lembrei. Da enfermagem, me formei obstetra. Na verdade, queria fazer só obstetrícia na USP, mas foi o último ano e não consegui. Quando comecei, fazia os partos nos hospitais privados, então sempre trabalhei em hospital privado para fazer parto. Por incrível que pareça em 1986 já tinha feito 1.000 partos. Achei muito bom a humanização porque ela começou no serviço público. Sempre tive dois empregos, um público e um privado. Aqui, por exemplo, não tinha parto humanizado, começou há uns três anos. Comecei em 2007 a trabalhar em serviços com parto humanizado, para mim foi muito simples, foi só passar o teórico que tinha para a prática. No meu outro serviço público realmente é um CPN bem montado. Estou tentando aperfeiçoar este CPN, mas é difícil porque não depende só de você. É algo político. As pessoas já estão vendo que ganhar o bebê num serviço de parto humanizado é muito melhor, porque a mulher escolhe alguém da família para estar junto com ela, não se sente sozinha. Muitas vezes, não conseguimos dar atenção só para uma mulher o tempo inteiro, então o acompanhante faz o seu papel de colaborador, faz as massagens na mulher, ele vive o momento com a parturiente e dá mais valor para a mulher dele. O parto humanizado é isso: trazer o antigo, com conhecimento cientifico, promovendo um bem-estar para a mãe para o bebê. Isso favorece também a amamentação do bebê, que começa na primeira meia hora depois do parto. Temos conseguido muito sucesso nesta parte, tanto que aqui é Hospital Amigo da Criança. Quanto às posições, as mulheres não têm aceitado muito ganhar na posição litotômica. Aqui não fazemos analgesia, os banhos, os exercícios de balanço pélvico, de agachamento, deambulação têm favorecido muito e quando começam a entrar em desespero já está na hora de nascer. E ela colabora bastante. Nós recebemos a mulher com muita alegria e isso já transmite mais segurança a ela. De recurso, usamos o chuveiro, porque nossa banheira não foi bem instalada, está com problemas. Talvez com o ano político melhore. Uma boa assistência para mim é ter o material para trabalhar. É dar acolhimento, tratá-la de forma personalizada, pelo nome, assim como o nome do acompanhante. Isso é uma boa assistência e causa a evolução do trabalho de parto. Se ela passou bem esse momento vai ter sempre uma boa lembrança. Aqui temos notado que está sendo positivo, porque elas estão vindo, voltando e indicando para as colegas. O retorno dela com alegria, vindo agradecer reflete minha boa assistência. Me sinto satisfeita a cada parto que faço. Se não fizer parto, não trabalhei. Aqui, somos em três trabalhando, tem um volume grande, nos dividimos. Muitas vezes fico mais no pré-parto, ou na burocracia, porque tudo temos que registrar. Eu amo fazer parto, acho que vivo para isso. Não quero outra coisa, é um hobby, uma terapia. Gosto do que faço e faço porque gosto. Minha experiência aqui é muito grande, é muito boa. Oriento as meninas que vem pedir ajuda, mas não gosto de lecionar, gosto de viver somente aquele momento. Não gosto de levar preocupação para minha casa. Mas, então minha experiência é: eu gosto, eu ensino". 


\section{OS ESQUEMAS CONCEITUAIS, OS DESCRITORES CULTURAIS E O SUBTEMA CULTURAL}

DC1 - Um modelo assistencial implementado na medida do que foi possível: o processo de transformação do CO em CPN

- A convergência das profissionais para o serviço

A paixão pela obstetrícia

A enfermagem obstétrica como um dom

- A existência de um CO com as seguintes características:

Quanto à assistência obstétrica:

- Ausência do acompanhante

- Disposição de gestante em decúbito dorsal horizontal

- Métodos para alivio da dor não eram praticados

- Quantidade excessiva de partos

Quanto ao turno de trabalho

- Enfermeiros obstetras trabalhando em regime de turnos

Quanto à planta física

- CO e CC funcionando no mesmo ambiente

-Os profissionais e suas resistências à proposta de transformar o CO em CPN

Técnicos de enfermagem

- Necessidade de desenvolver atividades até então não realizadas

Médicos

- Receio de inovar a assistência obstétrica

Enfermeiras

- Resistência à presença do acompanhante

-O processo de implementação do CPN

-Enfermeiras convidadas para estruturar o CPN

- Criação dos protocolos e rotinas

- O processo de aquisição dos materiais

- Aquisição dos materiais inadequados 
A convergência destas enfermeiras ao CPN ocorreu mediante indicação de amigos com os quais trabalhavam em outros serviços de saúde.

Uma identificação profunda com a assistência obstétrica surgiu ao longo da trajetória de vida das enfermeiras. O primeiro contato com a assistência ao parto foi determinante para muitas delas terem escolhido a enfermagem obstétrica como profissão. $\mathrm{O}$ exercício e a experiência profissional adquiridos durante os anos colaboraram para surgimento do sentimento de grande realização pessoal e profissional.

"Desde a graduação, quando passei na disciplina de obstetrícia, já sabia que ia ser obstetriz, fiz adorei e não sai mais" $(3,7,8,10)$.

A obstetrícia apareceu como a única área de identificação dentro da enfermagem. Percebeu-se que as enfermeiras tinham uma intensa paixão pela obstetrícia de forma pois todas que se fizeram a escolha por esta profissão não a abandonaram mais:

“... fazia parto na minha cidade como curiosa. Neste ano vim para São Paulo fazer a pós-graduação em obstetrícia. Era só com isso que me identificava na enfermagem"(1).

"No segundo ano de graduação me apaixonei pela obstetrícia, fiz a pós-graduação e desde então nunca parei de trabalhar" (9).

A enfermagem obstétrica foi entendida como um dom herdado desde a concepção. É como se ela tivesse sido transmitida pelos ancestrais, fruto de uma aptidão natural que os membros de sua família tinham e que se manifestava desde o nascimento.

"Fiz enfermagem obstétrica porque está no meu sangue. Minha avó paterna era parteira curiosa” $(7,10)$.

O interesse pela obstetrícia decorreu também do fato de terem trabalhado em serviços que seguiam o modelo de assistência humanizada ao parto, ou por terem se identificado com os docentes da área durante o curso de graduação em enfermagem. 
"O interesse surgiu devido ao contato no Hospital Santa Marcelina onde trabalhava, que segue a linha de parto humanizado" (6).

“ Fiz minha graduação na Bahia, tive uma professora na área materno- infantil que era enfermeira obstetra e me identifiquei com a área por causa dela ” (5).

As enfermeiras apresentaram em comum o fato de terem experiências de trabalho no contexto hospitalar. A maioria delas tinha experiência anterior de trabalho em maternidades ou em Centros de Parto Normal. Duas enfermeiras também tinham experiência na docência em enfermagem.

“Sou enfermeira obstetra há 25 anos, sempre atuei na área. No setor de patologia obstétrica ou no próprio parto na Maternidade. Hoje em dia sou docente também" (1, 3, 5, 8, 9).

A experiência anterior em serviços similares levou-as a estabelecer comparações entre a assistência e as condições estruturais oferecidas no CPN do HMMAA e as demais instituições onde já tinham atuado anteriormente. As enfermeiras que tinham experiência em Centro de Parto Normal fizeram comparações específicas e relataram que o CPN do HMMAA não estava funcionando como deveria.

As enfermeiras relataram que, antes de 2007, existia um centro obstétrico com características específicas, as quais a proibição da presença do acompanhante durante todo o período de internação.

Quanto à assistência obstétrica, a gestante era mantida em decúbito dorsal horizontal durante todo o trabalho de parto. Isto decorria do fato de não haver espaço físico suficiente para a deambulação, tampouco havia uma diretriz institucional que incentivasse a realização da assistência com esta característica. Não eram realizados exercícios ou não se usava qualquer tipo de recurso para progressão do trabalho de parto ou para produzir o relaxamento da mulher. Desta forma, os métodos não farmacológicos para promover o alívio da dor não eram praticados. 


\begin{abstract}
"O que mudou também foram os exercicios, que antes não fazíamos na paciente, não colocávamos na bola, cavalinho, andava muito pouco, a paciente era mantida deitada" (1).
\end{abstract}

Relataram que naquela época existia uma excessiva demanda de trabalho, pois prestavam atendimento a cerca de mil parturientes por mês. Além desta elevada carga de trabalho, associava-se o desgaste provocado pela jornada de trabalho, pois cumpriam uma escala de 12 horas de trabalho e 36 de descanso, usualmente denominada como escala 12 por 36.

\title{
Nesta Maternidade, o centro obstétrico $(\mathrm{CO})$ e o centro cirúrgico, que
}

funcionavam no mesmo ambiente, ficavam em local próximo ao pronto-socorro do hospital. Desse modo, tanto as parturientes de alto risco quanto as de baixo risco eram atendidas simultaneamente e compartilhavam as mesmas dependências físicas. Neste contexto, o atendimento dos partos de baixo risco era de responsabilidade da equipe de enfermagem.

\footnotetext{
"Na época, não existia o parto humanizado. Era o setor de Centro Cirúrgico e CO juntos, onde é o CPN hoje era um prontosocorro, o volume era muito grande, cerca de mil partos por mês. Trabalhava quarenta horas, plantão 12 por 36 " $(1,4)$.
}

Em 2007, os profissionais foram notificados de que o CO seria transformado em um CPN. Naquela ocasião, alguns se posicionaram contrariamente à ideia da implementação de um CPN naquela instituição. Esta resistência, observada sobretudo entre os técnicos de enfermagem e a equipe médica, era motivada pela necessidade de ampliar o rol de atividades até então desenvolvidas. Havia também o temor em relação à necessidade de inovar a assistência ao parto.

\footnotetext{
“... a administração viu a necessidade de abrir este Centro de Parto numa linha de parto humanizado e realmente foi uma luta parra abri-lo, porque houve resistência da equipe, como um todo, até dos auxiliares, por não querer ficar direto na assistência no CPN, além de também questões políticas" (6).
}

Algumas enfermeiras se mostraram resistentes à inserção do acompanhante durante o período de internação da mulher. Tinham a crença de que o acompanhante poderia exercer alguma interferência na assistência que estava sendo prestada pelo profissional. No processo de OP, percebi a existência de enfermeiros 
que ainda eram resistentes à presença dos acompanhantes. Ouvi queixas a respeito dos acompanhantes, com a alegação de que eles atrapalham o desenvolvimento da assistência, sobretudo porque emitem opiniões a este respeito. Tive a oportunidade de presenciar um enfermeiro se irritando e se retirando do local da assistência em consequência do conflito que tinha surgido na relação com o acompanhante.

"Eu mesma não queria porque achava que o
acompanhante perto interferiria e a paciente ficaria mais
manhosa" (1).

No processo de criação do $\mathrm{CPN}$, algumas enfermeiras foram convidadas a participar do planejamento da assistência no CPN que seria inaugurado. Desse modo, participaram ativamente da elaboração dos protocolos assistenciais, das rotinas de serviço, da lista de materiais e puderam opinar a respeito dos equipamentos a serem adquiridos. As enfermeiras que foram solicitadas a realizar este trabalho já compunham o quadro de profissionais do $\mathrm{CO}$ e tinham experiência prévia de trabalho em CPN. Portanto, tomaram como base os modelos assistenciais que vigoravam nos CPN do Hospital de Vila Alpina, Hospital Geral de São Mateus e Hospital Leonor Mendes de Barros.

Relatam que o CPN do HMAA, à época de sua inauguração, contava com protocolos assistenciais que possibilitavam prestar assistência conforme o recomendado pelo governo brasileiro. Entretanto, os equipamentos que foram adquiridos pelo hospital eram inadequados,pois divergiam do que foi proposto por elas na fase de planejamento do CPN. As profissionais avaliaram que, provavelmente, a aquisição destes equipamentos, que não eram os sugeridos e adequados para a assistência, foi feita para reduzir custos. Havia também a influência dos interesses políticos nesta questão.

“... fui convidada para começar a planejar como seria, então nós associamos rotinas de outras unidades, várias coisas, era para ser perfeito aqui. Toda a correção que fizemos foi encaminhada para a nossa coordenadora, da coordenadora para a secretaria. Só que politicamente não veio nada do que para ter feito"( 3).

Algumas enfermeiras relatam não ter tido conhecimento a respeito do convite feito para algumas pessoas, para colaborar na estruturação do CPN. 
Queixaram-se do fato de não ter havido um canal de comunicação entre a administração do hospital e a equipe obstétrica acerca, para dialogar a respeito de assuntos pertinentes à criação do CPN no hospital.

"Quando fizeram a compra disso tudo ninguém chamou um conhecedor do parto humanizado" (4, 9). 


\section{DC2 - Valorização da assistência no Centro de Parto Normal}

\section{- Crenças relativas à "boa assistência”}

Estabelecimento de comunicação interpessoal adequada

Tratamento personalizado à gestante

Oferecimento de acolhimento

Existência de material necessário ao atendimento

Trabalho em equipe

Atenção às necessidades da parturiente

Domínio do conhecimento técnico

\section{- Desenvolvimento de práticas humanizadas}

Promoção de ambiente familiar

Promoção da presença do acompanhante

- Aspectos positivos - Promoção do acolhimento, sensação de segurança, ambiente familiar e respaldo ao profissional

- Aspectos Negativos - Finalidade restrita à satisfação da curiosidade, ausência de suporte à mulher e interferência na assistência

- Redução das práticas intervencionistas

Liberdade na alimentação

- Estabelecimento de vínculo com gestantes

- Protagonismo do parto atribuído às gestantes

- Promoção da fisiologia do parto e métodos alternativos de controle da dor

Cavalinho

Banho de imersão

Uso da bola suiça

Massagens

Deambulação

- Estabelecimento de relacionamento profissional construtivo

Empatia em relação à parturiente

Fornecimento de informações sobre o progresso do parto

- Autonomia na atuação profissional 
Os profissionais relataram que a mudança do modelo de assistência ao parto, do tradicional para humanizado, permitiu perceber a ocorrência de uma mudança nos próprios valores em relação à assistência ao parto. Esta transformação fez com que os profissionais tenham passado a visualizar a mulher como o centro do processo do nascimento.

\footnotetext{
"A humanização melhorou bastante por parte dos enfermeiros obstetras, da equipe, da forma como tratam as pacientes, respeitando suas necessidades e desejos, tanto para se alimentar, caminhar, quanto ao soro". (6)
}

As profissionais atribuíram grande valor à filosofia assistencial existente no CPN. Este é visto como um modelo de inovação da assistência, diferente da cultura institucionalizada que predomina nos hospitais e maternidades em geral. Elas perceberam a nítida diminuição na frequência das intervenções no processo de parto e no surgimento de intercorrências.

\footnotetext{
"O parto humanizado é isso: trazer o antigo com conhecimento cientifico, promovendo um bem-estar para a mãe e para o bebê. Isso favorece também a amamentação do bebê, que começa na primeira meia hora depois do parto". (10)
}

As enfermeiras possuem muitas crenças relativas à boa assistência no modelo adotado neste CPN. Acreditam que na assistência ao parto desenvolvida segundo este modelo, a mulher é contemplada com uma assistência adequada desde o trabalho de parto até o puerpério, por se tratar de um ambiente diferenciado.

Acreditam na necessidade de estabelecer uma comunicação interpessoal adequada com a parturiente. Isto requer que o profissional se reporte à mulher de forma respeitosa e fique atento às necessidades referidas por ela, de modo a promover a ideia da mulher como principal sujeito do processo, ou seja, a protagonista do processo de nascimento. O tratamento personalizado, o que inclui a referência à mulher por meio de seu nome e a sua consideração como ser social, cultural e de sentimentos próprios, foi valorizado pelos profissionais. A necessidade de oferecer acolhimento às parturientes, para proporcionar-lhes o suporte necessário no momento da dor, da incerteza e da ansiedade, próprios ao processo de parto, constitui uma premissa destas profissionais. 
Acreditam que isto requer a existência de material adequado para que se possa prestar o atendimento com qualidade.

"Uma boa assistência é ter o material para trabalhar, dar o acolhimento que é tudo para a parturiente. É tratá-la de forma personalizada pelo nome, assim como perguntar o nome do pai da criança se for ele que estiver acompanhando". (10)

O trabalho em equipe foi considerado fundamental para o oferecimento de assistência adequada à mulher. Acreditam que cabe à equipe multiprofissional estar em conformidade com as práticas assistenciais preconizadas na instituição e permanecer em harmonia com os demais colegas. Julgam que esta união, associada ao domínio do conhecimento técnico adquirido por meio do estudo, é fundamental para a assistência adequada à parturiente.

\footnotetext{
"Uma boa assistência é o trabalho em equipe $e$ o conhecimento técnico, para ter o sucesso no seu trabalho é preciso estudar muito”. (9)
}

Em suas narrativas, foi possível perceber que as profissionais fazem o que está ao alcance delas para desenvolver práticas humanizadas no cotidiano assistencial. Destacaram a importância da promoção de um ambiente familiar, concretizado por meio da presença do acompanhante e o estabelecimento de vínculo com as parturientes.

\footnotetext{
"As pessoas estão começando a ver que ganhar o bebê num serviço de parto humanizado é muito melhor, porque ela leva a família junto com ela. Escolhe alguém de seu ambiente familiar”. (10)
}

Relataram também que a mudança do CO para CPN fez com que alguns enfermeiros obstetras, que apresentavam resistências à presença do acompanhante no pré-parto e parto, mudassem de opinião, depois de observar os benefícios proporcionados pelos acompanhantes. Foram citados alguns aspectos positivos que derivaram da presença do acompanhante, dentre eles: promoção do acolhimento, sensação de segurança para a parturiente, criação de um ambiente familiar e oferecimento de respaldo ao profissional. Avaliaram que os acompanhantes observam as condutas adotadas pelos profissionais e, caso surjam problemas, estão cientes de tudo que os enfermeiros obstetras buscaram realizar. 
"Vi que é ótimo porque o acompanhante vê como a paciente é tratada, tenho o respaldo dele quanto a minha conduta. É positivo para a paciente ter um acompanhante para se sentir mais segura". (1)

Valorizaram também os papéis exercidos pelos acompanhantes. Perceberam que eles auxiliam no desenvolvimento da assistência, no trabalho de parto, realizando massagens, fornecendo apoio emocional e incentivos, de forma verbal. Acreditavam que esta participação ativa promove a integração dos próprios acompanhantes no processo de parto e aumenta o valor atribuído à companheira.

"Muitas vezes não conseguimos dar atenção só para uma mulher o tempo inteiro; então o acompanhante faz o seu papel de colaborador, faz as massagens na mulher, ele vive o momento com a parturiente e dá mais valor para a mulher dele”. (10)

Atribuíram importância ao preparo para o parto, tanto da parturiente como dos acompanhantes, desde a fase gestacional. A assistência pré-natal foi considerada fundamental para que o casal seja devidamente orientado e apto para que o suporte à gestante seja oferecido adequadamente no momento do nascimento.

“... os familiares podem entrar e participar; isso é bom, mas acho também que eles têm que participar do pré-natal, não é só no momento de ver o parto, porque alguns veem só por curiosidade. Mas não é assim, o acompanhante tem que ser uma pessoa que dê força para ela, que saiba o que vai acontecer e o que fazer no momento de desespero...". (8)

Julgaram que a ausência deste preparo acarreta danos para a assistência, pois, além do objetivo da presença estar restrita à curiosidade, acabam interferindo na conduta dos profissionais, criticando as práticas desenvolvidas ou impedindo a realização de alguns procedimentos. Estes inconvenientes geram tensão em todos os envolvidos, sobretudo para a parturiente.

\section{Esforços para a redução das práticas intervencionistas e restritivas} foram destacados, dentre os quais, a prerrogativa da livre alimentação durante o trabalho de parto, uma proposta distinta da restrição alimentar total geralmente adotada no modelo tradicional de assistência ao parto. Atenção à retirada do foco de luz na sala de parto durante o dia e manutenção das luzes apagadas à noite foi citada como forma de humanização da assistência à gestante e seu recém-nascido. 
"Eu e mais algumas enfermeiras não usamos o foco para não ser agressivo para o bebê e a noite eu apago a luz e deixo apenas um foco para a condução, depois faço a interação entre mãe e filho, deixo por volta de vinte e trinta minutos se ela quer ficar com o bebê". (6)

Avaliou-se que a promoção de ambiente acolhedor e familiar para as gestantes estava associada à preocupação de estabelecer vínculo com elas. Consideraram que a maneira pela qual o profissional se relaciona e conduz o trabalho de parto interfere no sentimento de bem-estar da parturiente. Relataram que, quando um bom vínculo é estabelecido com a gestante, esta demonstra maior segurança e confiança na equipe profissional.

\section{"Nós já recebemos a mulher com muita alegria e isso transmite segurança a ela”. (10)}

Observaram que o novo modelo assistencial proposto com a criação do CPN procurou mudar o foco da assistência, que passou a se direcionar para a gestante como centro do processo do nascimento. Desta forma, o protagonismo do parto foi atribuído às próprias gestantes.

Durante a condução do trabalho de parto, foi valorizada a preservação do parto como um processo fisiológico. Isto é, desenvolvido mediante a redução do uso da ocitocina sintética e a estimulação da progressão do trabalho de parto por meio de métodos alternativos de controle da dor. Avaliaram que a ausência da analgesia no trabalho de parto tem favorecido a progressão fisiológica do parto.

\footnotetext{
"Nossa equipe trabalha com humanização: leva para o chuveiro, para bola, conversa, se realmente tem uma dinâmica muito forte a ocitocina é suspendida”. $(6,7)$

"Quanto às posições, as mulheres não têm aceitado muito ganhar na posição litotômica. Aqui não fazemos analgesia, os banhos, exercícios de balanço pélvico, agachamento, deambulação, têm favorecido e quando já começam a entrar em desespero já está na hora de nascer". (10)
}

Muitos métodos são utilizados para promover a progressão do parto. Foram citados o uso do cavalinho, o banho de imersão e o estímulo à deambulação. $O$ banho de imersão, o utilizado com maior frequência, propicia o melhor resultado na avaliação dos profissionais, pois, além de auxiliar na dilatação 
do colo do útero, ele proporciona um ambiente íntimo para a gestante e seu acompanhante.

\footnotetext{
"Uma das coisas que vejo que tem muito sucesso é a hidroterapia. A mulher esquece aquele ambiente hostil, porque o banheiro é um ambiente íntimo, só fica quem você ama, e os resultados são muito bons". (9)
}

A bola suíça também é usada para realizar exercícios de balanço pélvico. Estes exercícios, embora considerados úteis para a progressão do parto, são rejeitados por algumas gestantes pelo fato de causar desconforto e a sensação dolorosa.

"A grande maioria das mulheres aceita bem tudo, mas algumas não ficam na bola porque referem que doe demais $e$ então orientamos, não podemos obrigar, dizemos a ela que se ficar assim”.

As massagens no cóccix são realizadas para aliviar a dor, proporcionar relaxamento e estimular a descida do bebê. A realização desta prática é ensinada aos acompanhantes e estes dão continuidade no atendimento. Os recursos disponíveis na instituição são utilizados na medida do possível, dentro do que é preconizado.

\footnotetext{
“... dentro do que a instituição tem para nos oferecer $e$ o que é preconizado, tentamos usar os recursos”. (9)
}

Durante o processo de OP foi possível notar que, embora em suas narrativas os profissionais mencionem a valorização e o desenvolvimento dos métodos alternativos de controle da dor, no cotidiano assistencial tais métodos não são explorados por muitos deles. Pude perceber que o método mais utilizado e incentivado é o banho de aspersão e a deambulação. Os demais recursos são usados somente pelos profissionais deliberadamente ativistas e defensores da assistência humanizada ao parto.

O estabelecimento de relacionamento profissional construtivo com as gestantes foi valorizado pelos profissionais. Acreditavam que este relacionamento deve ser desenvolvido por meio da empatia em relação à parturiente, em cujo processo cabe ao profissional identificar e procurar realizar o que considerar ser o 
melhor para a gestante, entre eles o fornecimento de informações sobre o progresso do parto.

"Gosto de fazer parto partejar, do contato com a gestante porque ela é muito carente, adoto todas como minhas filhas, ajo como se fossem minhas filhas e torno uma leoa diante da defesa delas". (9)

Acreditavam que o fornecimento de informações sobre o progresso do parto, para que a mulher tenha conhecimento pleno dos procedimentos realizados, esclarecimento sobre as possibilidades disponíveis no CPN, informações sobre seus direitos, são responsabilidades que cabem aos profissionais.

"Explico à mulher como é o atendimento no CPN, que pode tomar banho, pode comer, que vai investir no parto normal, mas se for necessário é feito a cesárea. Vou explicando o porquê do soro, porque a bolsa rompeu”, $(4,5)$

Referiram que, diferente de outros modelos de assistência ao parto, no qual a enfermeira obstetra não é a profissional condutora do processo de assistência ao parto, no CPN elas possuem autonomia na atuação. Isto foi visto como um aspecto positivo, pois havia a possibilidade de reduzir as intervenções na progressão do parto. 
STC1 - Este Centro de Parto Normal não é como deveria ser: inúmeros obstáculos dificultam a prestação da assistência humanizada

- Não seguimento sistemático do protocolo assistencial pelos profissionais

\section{Médico obstetra}

- Prescrição médica indiscriminada de ocitocina

- Internação precoce

- Preferência cesárea

- Internação de pacientes com patologias ou fora de trabalho de parto

- Inexperiência

- Postura hegemônica

\section{Médico neonatologista}

- Clampeamento precoce do cordão umbilical

- Ausência de preocupação com a promoção da interação mãe-filho

Técnico de enfermagem

- Absenteísmo

- Sobrecarga de trabalho

\section{Enfermeiras}

Elevada taxa de episiotomia

Crenças referentes à parturiente:

- Ausência de colaboração das parturientes

- Multíparas pouco colaborativas

- Inadequação da planta física e equipamentos

Banheira estreita e sem barra de segurança

Chuveiro, bola suiça e cavalinho em quantidade insuficiente

Inadequação da cama de parto

Não utilização das suítes de parto

Ausência de privacidade no pré-parto

Insuficiência de leitos para o atendimento da demanda

Desenvolvimento de tarefas em ambientes separados do CPN

- Criação do CPN como produto de interesses políticos 


\section{A ausência de preparação dos profissionais na transição para o CPN}

foi problema referido, que ocorreu no processo de transição do CO para CPN, e isto apresentou implicações para a assistência prestada. A administração do hospital não ofereceu preparo para os profissionais, como palestras sobre a filosofia da assistência e o protocolo assistencial do CPN. Consequentemente, os profissionais, que eram originários de diversas culturas institucionais, empregavam cada qual a sua prática na assistência à gestante. Este fato gerou problemas de falta de sistematização nas condutas assistenciais.

"Quando mudou de Centro Cirúrgico para Centro de Parto Normal foi falado do acompanhante, que ia ter exercício, mas não teve palestra instrutiva para os profissionais...". (1)

\section{“... quanto aos funcionários, não fizeram treinamento, não nos adequaram a um Centro de Parto Normal”. (8)}

Segundo a avaliação das profissionais, a ausência de unanimidade nas condutas representa um grande obstáculo que deve ser enfrentado, pois as divergências existentes na atuação e atenção às gestantes são grandes. A assistência obstétrica é peculiar à equipe profissional de cada plantão, cabendo aos profissionais se adaptarem à equipe e adotarem condutas que costumeiramente são adotadas naquele plantão. Os protocolos, que antes estavam disponíveis para consulta, foram retirados pela administração para atualização e reformulação. Poucos profissionais referiram terem tido acesso a esta documentação.

Consequentemente, a ausência de seguimento e de conhecimento acerca dos protocolos institucionais provocou divergência nas condutas assistenciais. Algumas enfermeiras relataram desconhecê-los e sugeriram o estabelecimento de um protocolo padrão que deveria ser adotado por todos os profissionais atuantes no CPN.

Avaliaram que a interação da equipe multiprofissional, que tem que estar consciente da filosofia do CPN e de seu papel como facilitadores no processo, seria determinante para o sucesso do parto humanizado. Apesar de relatarem um relacionamento pessoal agradável com a equipe, mencionaram várias dificuldades de interação entre os membros da equipe multiprofissional na prática assistencial. 
Atribuíram a ocorrência destas dificuldades à divergência de opiniões e de condutas relativas à assistência.

"Estou há um ano e vejo que falta interação da equipe multidisciplinar". (7)

Avaliaram que essas dificuldades se concentram, sobretudo, nos profissionais médicos e em menor grau nos técnicos de enfermagem.

"Dificuldades, temos muitas, porque nós temos uma conduta e o médico quer outra, mas acho que com respeito você acaba chegando em um objetivo comum, que é a assistência à paciente, porque o filho é dela. A esposa é do marido e não é nossa, nós somos somente os condutores dessa história”. (9)

Foram feitas referências à postura arrogante demonstrada por alguns médicos obstetras, que não aceitavam as opiniões emitidas pelas enfermeiras. Acreditavam que a existência desta atitude hegemônica refletia sobre a assistência, pois os protocolos não eram seguidos.

\section{"Tive muitos problemas com médicos, pois muitos são arrogantes e não estão em harmonia cumprindo protocolos". (7)}

A hegemonia profissional médica provocava também a prescrição indiscriminada de ocitocina sintética, que contraria a filosofia do CPN. No CPN prevalece a ideia de reduzir as práticas intervencionistas. Entretanto, a maioria das gestantes já é encaminhada pelos médicos ginecologistas do pronto-atendimento ao setor de pré-parto com prescrição médica de ocitocina sintética.

A inexperiência foi citada como uma grande dificuldade apresentada pelos médicos obstetras. Muitos deles demonstravam insegurança, cediam às pressões dos familiares ou internavam as mulheres por comodidade.

"as pacientes teriam que ser internadas em trabalho de parto, mas isso não acontece; pode ser pela insegurança do médico, por comodidade ou a família vem várias vezes e o médico acaba internando". (1)

As enfermeiras mencionaram que a internação precoce das gestantes por parte dos médicos obstetras era uma prática recorrente. As gestantes eram 
internadas fora do trabalho de parto. Consequentemente, enfrentavam dificuldades para prestar assistência humanizada. Referiram que as gestantes acabavam ficando muitas horas em trabalho de parto dentro da instituição e ficavam exauridas. Além disso, essa internação precoce gerava a necessidade de número excessivo toques vaginais.

"Não dá para dar uma assistência muito humanizada porque tem mulheres em início de trabalho de parto".

Outra dificuldade mencionada pelas enfermeiras foi à internação de pacientes com complicações obstétricas ou patologias no CPN. Estas mulheres deveriam ser encaminhadas para o $\mathrm{CO}$ ou para a GO. Entretanto, muitas delas eram internadas no CPN.

\footnotetext{
"Tem paciente com um centímetro, colo grosso que interna. A indicação é pós-data, mas não deve ir para o CPN, é paciente de enfermaria”. (1)
}

Estas internações injustificadas, tanto precoces quanto de gestantes de outros setores, causavam a lotação desnecessária do CPN e geravam má qualidade na assistência, tendo em vista que o número de leitos do CPN era reduzido em proporção à demanda da Maternidade. Consequentemente, muitas mulheres eram obrigadas a permanecer sentadas em cadeiras aguardando por uma vaga em leito, por longo período de tempo.

Outra dificuldade relatada foi a preferência de alguns médicos obstetras pela cesárea. Segundo o olhar das enfermeiras, esta preferência estava associada à ausência de conhecimento técnico para realizar o parto normal. A insegurança, como mencionada anteriormente, remete os profissionais a praticarem cesárea por medo de problemas futuros por erros médicos.

“... mas essa humanização é necessária da classe médica, que não está adaptada, preferem fazer uma cesárea e não ter problemas futuramente, do que precisar saber se vai evoluir ou não”. (6)

As enfermeiras relataram que, logo após o nascimento, a prática do estabelecimento de vínculo do recém-nascido com sua mãe, mediante contato pele a 
pele, foi prejudicada. Observaram que, em geral, os médicos neonatologistas ficam ao lado dos enfermeiros e os apressam a pegar rapidamente o recém-nascido, com intuito de realizar os procedimentos de rotina, dentre eles a aspiração das vias áreas e a aspiração gástrica. Consequentemente, a ausência da promoção da interação mãe-filho acontece por influência dos neonatologistas e pela alta demanda de nascimentos, que acabam apressando os profissionais a concluírem o parto com maior rapidez. Como consequência, ocorre também o clampeamento precoce do cordão umbilical. Em contrapartida, relataram que em alguns plantões havia a possibilidade de desenvolver práticas humanizadas em decorrência do entrosamento ou do nível de conscientização dos membros da equipe multiprofissional.

"Existem resistências, mas tentamos levar na esportiva. Já falei para o Neo assim 'doutor deixa o bebê com a mãe, se não este CPN ao invés de Amigo da Criança vai ser inimigo da criança'. Assim os Neos sabem que neste plantão existe essa conscientização e não chegam nem perto”. $(5,6)$

"O parto humanizado preconiza deixar o bebê em cima da mãe, demorar para cortar o cordão, parar o batimento, mas o volume aqui é muito grande, não dá tempo para fazer tudo isso, quando dá nós fazemos". (1)

Quanto aos técnicos de enfermagem, o absenteísmo foi um problema frequentemente citado. Avaliaram que a origem deste problema estava na grande quantidade de profissionais concursados. Esta problemática originava outras, como a sobrecarga de trabalho para os profissionais presentes no plantão e a geração de lacunas na assistência, consequentes à pequena quantidade de profissionais no plantão.

"Com a equipe de técnicos e auxiliares de enfermagem, como é um hospital público, muita gente é concursada e tem muita falta. (...) mas não temos problemas com eles, porque são muito sacrificados também por falta de funcionários”. $(1,9)$

As enfermeiras obstétricas que nunca tiveram contato anterior com o modelo de assistência desenvolvido em CPN referiram a superação das crenças e práticas, advindas do modelo tradicional de assistência, mediante o auxílio oferecido dos colegas de profissão. Semelhante ocorrência foi relatada pelas técnicas de enfermagem. 
"Quanto às técnicas, depois de alguns cursos que foram feitos e a partir do convívio conosco, hoje já trabalham como num Centro de Parto". (6)

As profissionais avaliaram que a assistência ao parto em um CPN requer estrutura física e de equipamentos adequados. No entanto, naquele CPN existiam muitas dificuldades provocadas pela inadequação da planta física e equipamentos.

Quanto à inadequação dos equipamentos, foram feitas referências à banheira, que já era subutilizada e foi colocada em desuso nos últimos tempos. Aparentemente, ela foi mal instalada, pois as parturientes com sobrepeso enfrentam dificuldades para utilizá-la devido ao fato de ser estreita e sem barras de segurança. Outro aspecto problemático mencionado foi a dificuldade relativa à sua higienização. As profissionais não conheciam os procedimentos adequados para isto.

"A banheira não é utilizada. Ela não tem suporte de apoio, é estreita uma paciente obesa tem dificuldade”. (1)

O número reduzido de chuveiros também foi mencionado como um fator agravante das más condições de instalação do CPN. Na avaliação destas profissionais, deveria haver uma quantidade deste recurso, tendo em vista a quantidade de parturientes atendidas.

\footnotetext{
"Temos só dois cavalinhos, uma bola e um chuveiro. Então, não temos mais chuveiros para colocar as mulheres, a condição podia ser melhor". (7)
}

Avaliaram que a quantidade de bolas suíças e cavalinhos também era reduzida. À época da inauguração foram adquiridas duas bolas, mas uma delas furou e há apenas uma em funcionamento. Foi referida a inadequação das camas de parto, que restringe as possibilidades para posições de parto não litotômicas.

Quanto à inadequação da planta física, as salas de parto utilizadas atualmente foram preparadas de forma improvisada, pois o local onde as suítes de parto se encontram estava fechado. 
"Aquelas suites de parto teoricamente foram inauguradas, mas usamos poucos dias e foram desativadas. Aparentemente, porque está com problemas". (4, 5, 6, 9)

Foi observada uma discordância entre as opiniões das enfermeiras em relação à não utilização das suítes do $\mathrm{CPN}$. Algumas relataram que a dificuldade era a longa distância entre as suítes de parto e o pré-parto. Outras, por sua vez, referiram não haver profissionais suficientes para prestar assistência ao parto em dois ambientes distintos.

"Acredito que a falta de funcionários prejudica porque nem sempre tem funcionários para deixar nos dois ambientes”. (1)

Entretanto, algumas acreditavam que a distância não era o que impedia a utilização das suítes de parto, pois tinham condições e preparo suficientes para atender gestantes em ambos os ambientes. Acreditavam que o que as impedia de utilizar ambos os recursos físicos, de forma simultânea, eram os valores dos profissionais, que ainda apresentavam dificuldades em relação ao modelo de assistência humanizada ao parto.

\author{
"Ninguém abre o Centro de Parto. Eu faria o parto lá, com \\ certeza”. $(3,6)$
}

Acreditavam também que nas suítes de parto, a cama de parto era muito baixa. Este fato acarretava a dificuldades de realizar o parto, pois, muitas vezes, havia a necessidade da sutura, que demandava a adoção de uma disposição corporal prejudicada.

\footnotetext{
"A equipe também se queixava das camas que não eram próprias para isso, muito baixas, a cama não subia e foi muito criticada”. (4,9)
}

Muitas expressaram expectativas em relação à utilização efetiva do CPN, de forma humanizada. Apesar das dificuldades mencionadas, tinham o interesse de sua reabertura, tendo em vista que a aceitação por parte da equipe tinha melhorado (atualmente) se comparada à época da inauguração.

"na época, o que ouvíamos é que não era muito de interesse da administração, existia muita resistência dos médicos 
em não querer o Centro Humanizado. Mas houve muitas mudança na aceitação e talvez fosse possivel reabri-lo novamente." (3, 6)

Mencionaram também a defasagem em relação à estrutura do pré-parto. Este, que dispunha de cortinas finas para separar os leitos, possibilitava ver e ouvir, com clareza, o que acontecia no leito vizinho. Além disso, a cortina aberta possibilitava a exposição da mulher a outros acompanhantes que estavam presentes. Esta disposição dos leitos, separados apenas por cortinas, causava a ausência de privacidade, gerava constrangimentos e prejuízos à liberdade no momento do nascimento.

"No entanto, ter um quarto só, a banheira, ter privacidade, não existe, porque, apesar de ter cortina, você escuta o outro falando. Não é como deveria ser". (1)

Avaliaram que a quantidade de leitos na maternidade era em quantidade insuficiente para atendimento da demanda. Consequentemente, as puérperas tinham que aguardar cerca de duas horas sobre uma maca, dispostas no corredor, antes de serem encaminhadas para os quarto no Alojamento Conjunto.

"O pós-parto também é complicado porque não tem um lugar adequado para a mãe ficar. Então, ficam na maca e no corredor cerca de duas horas; não sou a favor, mas nós fazemos algumas coisas porque são preconizadas pela instituição”. $(1,6)$

As enfermeiras acreditavam que o desenvolvimento de outras tarefas em ambientes separados do CPN, como, por exemplo, o atendimento de cardiotocografias no pronto-atendimento, prejudicava a qualidade da assistência no $\mathrm{CPN}$ e o estabelecimento de vínculo com a parturiente.

"Não consigo fazer muito vínculo com a parturiente, pois a examino e logo tenho que sair do CPN para fazer os CTB da admissão”. (1)

No final de suas narrativas, as enfermeiras avaliaram que o esforço empregado para o desenvolvimento de práticas humanizadas na assistência ao parto se tornava muito cansativo, porque muitas questões estavam fora da alçada de suas decisões e responsabilidades. Avaliaram que as questões e os interesses políticos eram muito fortes, principalmente por se tratar de uma maternidade pública. Consideraram que a criação do CPN foi uma estratégia política. Houve uma 
grande encenação na ocasião de sua inauguração, mas ela não ficou como deveria ser.

"Ali tudo foi uma coisa política. Houve uma grande inauguração, mas o que realmente mudou no Amador Aguiar desde quando entrei foi a presença do acompanhante". $(1,7,10)$

Através da observação participante, percebi que os profissionais que trabalham ou já trabalharam em um modelo de Centro de Parto desenvolvem mais fielmente as práticas humanizadas de assistência, incentivam a mulher e dão liberdade para que se expressem como gostariam.

“... então, se a mãe quer gritar e não está interferindo na assistência, o bebê está bem, deixa gritar. Qual o problema? Se ela quer que grite junto, é capaz de eu gritar junto". (8)

Observou-se, porém, que as profissionais sem experiência anterior em assistência em CPN ou casa de parto cometem intervenções desnecessárias e a violência verbal com maior frequência. As mulheres que gritam no trabalho de parto eram consideradas como "descontroladas" e sofriam ameaças como "o parto não vai progredir" ou "haverá uma distócia". Quando a mulher não aderia à instrução da enfermeira, era denominada como "tigrona".

“...É igual a paciente que grita, grita, grita, distocio e você leva para a cesárea, a outra que está quietinha já pensa: "Ela gritou e vai pra cesárea. Eu vou gritar também”. Sempre falo se você quer gritar é um direito seu, mas também é um direito meu não ficar aqui para ouvir. Vou te ajudar, te examinar, mas ficar do teu lado ouvindo você gritar, não sou obrigada. Falo também que não adianta gritar porque primeiro a dor não vai passar, você não vai mandar oxigênio para o seu bebê e quanto mais você ficar desta forma mais o parto vai ser demorado. Claro que vai ter umas 'tigronas', já levei pesada”. (1)

Procuravam avaliar a necessidade da episiotomia, por meio da avaliação do períneo. Quando encontravam períneos resistentes ou fibrosados, “davam um piquezinho". Referiram que não eram todos os partos que requeriam episiotomia. Entretanto, no processo de OP, foi possível verificar que havia alta taxa de realização de episiotomia nos partos normais. 
“... mas quanto à Episio, já se vê no pré-parto os períneos bem resistentes, fibrosados. Por fim, dou um piquizinho, mas nem tudo tem que ser Episio”. (1)

Esclareceram que na época em que o número de fratura de clavículas estava frequente, houve pressão de seus superiores no sentido de realizar episiotomia de rotina e de forma acentuada.

"Tentamos fazer da maneira certa, mas, por exemplo, há pouco tempo veio um dos diretores aqui no momento em que eu estava fazendo o parto e disse "faça uma Episio bem aberta, bem grande", porque tinham alguns bebês nascendo com fratura de clavícula e eles achavam que era porque não fazia Episio”. (1, 4)

Este procedimento permanece sendo usado de rotina, pois acreditam que o seu uso facilita nas suturas, previne lacerações, reduz o tempo despendido no parto e previne fraturas de clavícula do $\mathrm{RN}$. 


\subsection{AS TÉCNICAS DE ENFERMAGEM, SUAS CARACTERÍSTICAS, SUAS NARRATIVAS, O ESQUEMA CONCEITUAL E O SUBTEMA CULTURAL}

A equipe de técnicas de enfermagem está disposta conforme a quadro 2 abaixo:

Quadro 2 - $\quad$ As Técnicas de Enfermagem e suas características. São Paulo, 2011

\begin{tabular}{|c|c|c|c|c|c|c|c|c|c|}
\hline Entrevista & Idade & Naturalidade & Religião & Estado Civil & Paridade & $\begin{array}{c}\text { Maior Grau } \\
\text { Escolaridade }\end{array}$ & $\begin{array}{c}\text { Tempo de } \\
\text { experiência } \\
\text { profissional } \\
\text { na área }\end{array}$ & $\begin{array}{l}\text { Tempo na } \\
\text { Instituição }\end{array}$ & $\begin{array}{c}\mathrm{N} \text { de } \\
\text { Empregos }\end{array}$ \\
\hline \multicolumn{10}{|c|}{ INFORMANTES-CHAVE } \\
\hline TE1 & 40 & São Paulo & Católica & Casada & 3 & $\begin{array}{l}\text { Técnico de } \\
\text { enfermagem }\end{array}$ & 2007 & 3 anos & 1 \\
\hline \multicolumn{10}{|c|}{ INFORMANTES GERAIS } \\
\hline TE2 & 43 & São Paulo & Católica & Viúva & 3 & $\begin{array}{l}\text { Técnico de } \\
\text { enfermagem }\end{array}$ & 2006 & 7 meses & 1 \\
\hline TE3 & 29 & São Paulo & Evangélica & Casada & 1 & $\begin{array}{l}\text { Técnico de } \\
\text { enfermagem }\end{array}$ & 2006 & 2 anos & 1 \\
\hline TE4 & 40 & São Paulo & Católica & Casada & 2 & $\begin{array}{c}\text { Técnico de } \\
\text { enfermagem }\end{array}$ & 2004 & 2 anos & 2 \\
\hline
\end{tabular}

Nesta pesquisa, observa-se que as 4 técnicas de enfermagem que colaboraram, tinham entre 29 e 43 anos, com média de 38 anos; todas eram naturais de São Paulo. A média de paridade era de um filho. Três eram casadas e uma viúva. Com relação ao maior grau de escolaridade, todas tinham curso técnico em enfermagem.

Quanto à religião, três declararam ser católicas e uma era evangélica. Quanto ao ano de término do curso técnico, o período foi de 2004 a 2007. Quanto ao tempo na instituição, variou de 7 meses a 3 anos, com média de 2 anos. A média de empregos das técnicas de enfermagem foi de 1 emprego, ou seja, a maioria trabalhava somente no HMMAA. 


\section{As suas narrativas}

TE 1: "Me arrependo de não ter feito enfermagem direto, mas estou contente com o que faço hoje. Me formei em 2007. Quando entrei aqui, vim direto para a UTI neo, porque adoro criança. No começo tinha muito medo, mas, com o tempo, as pessoas me receberam muito bem, me ensinaram. Hoje vai fazer 10 anos que estou aqui, o pouco que sei foram elas que me passaram. Isso, para mim, já é muito coisa. Gosto de onde estou trabalhando porque gosto de lidar com o ser humano, de trabalhar o lado psicológico, procuro ter paciência, brincar, ver a necessidade da paciente desde quando ela chega. Algumas têm muito medo, procuramos acalmá-las, outras têm muitas dúvidas, outras nem sabem o que vai acontecer. Então, vamos conduzindo tudo isso. O nosso trabalho é de recepcionar, fazer a burocracia de papéis, informar através de relatório tudo o que acontece com elas, desde uma eventualidade até o estado normal, sem nenhuma intercorrência. Temos que relatar tudo. Fazemos o procedimento invasivo, colhemos sangue. Tudo é protocolado, damos assistência da UTI até o pré-parto, sala de parto. Cuidamos do setor como um todo e orientamos a paciente em muitas coisas. Quando têm dúvidas sobre amamentação. Gosto muito de trabalhar aqui, seguimos o que a enfermeira passa para nós. O que é mais usado aqui é o banho, caminhada, a bola, nem tanto. Quando você faz esse trabalho de fisioterapia acaba ajudando no trabalho de parto. É uma maneira de acelerar o processo sem agressividade e a paciente consegue ter um resultado melhor. Quando a paciente não quer não forçamos, mas a incentivamos. A banheira não é usada por questão de higiene, para não colocar uma paciente que vai perder líquido, perder sangue. Mas ainda acho que os recursos disponiveis poderiam ser mais explorados. Não são pela falta de funcionários. Se fossemos abrir o Centro Humanizado teríamos que disponibilizar mais funcionários. Mas aqui se faz tudo o que pode. Precisamos ver o paciente como um ser humano. Como gostariamos de ser tratados. Não conseguimos utilizar dessa bem feitoria porque nem todos pensam da mesma maneira. Eu, por exemplo, sou subordinada. Se a enfermeira vem aqui e tem a conduta de colocar o bebê em cima da mãe, você respeita. Quando tem a intervenção de um médico, que diz para trazer o bebê, não sei o que fazer. Se você tem essa informação e consegue que todos entrem em sintonia com você, é feito o trabalho em grupo. Mas, infelizmente, alguns permitem outros não, e tenho que respeitar o que minha hierarquia manda. Uma boa assistência é enxergar o paciente como um ser humano, porque cada um tem um limiar de dor. Tem pacientes que são mais tranquilas, outras não, temos que saber respeitar os limites, prestar uma boa assistência psicológica. Não somente fazer uma medicação. Temos que aprender a ouvi-la. Fico muito satisfeita quando a paciente está bem, tranquila, porque quando sabe que a paciente precisa de algo e você não pode fazer fico insatisfeita. Pode ser uma coisa bem simples, mas não cabe a mim. Pode até ter um protocolo para aquilo, mas não faço, infelizmente, porque não está ao meu alcance. Fica insatisfeito então porque o bebê nasce mal por falta de assistência, não do técnico, mas de um superior. Quando o bebê nasce bem, amamenta com facilidade, fico muito feliz. Minha experiência se resume em aprendizado. Aprendi muita coisa aqui. Nossa equipe é boa e nos apóia e isso nos dá segurança. Minha experiência aqui é boa. É muito gratificante, estou muito feliz". 
TE 2: "Trabalhei em um asilo da prefeitura de Osasco durante 2 anos. Não tinha experiência em Hospital. Estou aqui há sete meses. Quando entrei aqui foi tudo novo, porque não conhecia as pessoas com quem eu ia trabalhar, o que eu ia fazer, mas todos me trataram e me ajudaram. Quando a mãezinha chega, tentamos acalmá-la porque isso é prioridade. Ela chora, chega nervosa, mesmo sendo o quinto filho, temos que acalmar e fazer os cuidados essenciais. Aqui temos as escalas dos plantões e cada dia de plantão você fica em um setor, seja do pré-parto, parto ou pós parto. No pósparto auxiliamos a mãe, o mais dificil é na sala de parto, principalmente quando é o primeiro filho. $E$ um sufoco para elas. Nós auxiliamos os enfermeiros, cuidamos do RN, depois olhamos sangramentos, orientamos como deve amamentar o bebê. Tem que ficar sempre atenta ao jeito da mãe. Se ela está sangrando, para evitar hemorragia. No nosso plantão somos todos bem unidos, porque se não o trabalho não evolui. É assim: os médicos nos ajudam. Se é necessário mesmo, nós já chamamos e fazemos o que tem que fazer. Teve uma vez que eu sai daqui chorando, porque a mãe sofreu muito, por causa da forma do atendimento da enfermeira. De repente, era a atitude que deveria ser tomada, mas como não estava atuando na área, só estudando, acabo não sabendo direito como funciona. Esse é o meu segundo emprego, e vejo que meu trabalho é ajudar. Acho legal a questão da humanização, mas não dá para fazer tudo que tem que ser feito. Então, faço o que posso. Tem dias que são bem dificeis porque o quadro de funcionários é pouco. Não conseguimos dar aquela assistência para a mãe, nem para o bebê, mas temos que dar, tem que olhar e fazer. Para mim, uma boa assistência é atenta a tudo o que acontece com a mãe antes e depois. Acho que isso é assistência, porque qualquer descuido pode ser fatal. Em resumo, temos que dar toda atenção e ficar atentos. Nós temos alguns recursos aqui que são necessários, mas ainda faltam muitos. Porque tem dias que aqui está cheio e não tem espaço para a mãe, para o acompanhante. Com muita gente também não temos espaço para trabalhar. A mãe fica sentada. Por isso tinham que abrir o CPN, já que tem. Não tem nada que impeça-os de abri-lo. A não ser a falta de funcionários. Acho que deveria abrir, porque tem gente para trabalhar na área. Ou talvez a prefeitura não tenha condições, porque funcionário tem sobrando. A demanda é grande, deveriam trazer mais gente para trabalhar e dar mais condições de trabalho. Minha experiência aqui tem sido ótima, tenho aprendido muito. Gosto muito de lidar com crianças pequenas". 
TE 3: "Comecei a gostar de obstetrícia depois que fui mãe. Queria vir para essa maternidade de qualquer jeito. Entrei aqui no alojamento conjunto, fiquei dois anos, mas queria ficar mais próxima ainda do RN. Agora estou aqui gostando muito. Minha rotina é verificar soro, posição venosa, ver se tem medicação. Preparamos para a mãe ir para a sala de parto. Fica aqui na sala de pré-parto, quando a enfermeira nos avisa, a levamos para a sala de parto. Lá tem os circulantes que ficam fazendo a parte técnica e nós sempre ajudamos a mãe e a enfermeira. Quando o neném nasce, damos os cuidados do RN, sempre ao lado da mãe, porque é um momento muito difícil para ela. Humanização, para mim, é ser cordial com a mãe. Ficar sempre atenta com as queixas dela e dar apoio psicológico. Pela minha experiência, sei que ninguém está preparada para passar por uma dor dessas. Então, fico sempre tranquilizando a mãe. Tentamos sempre tranquilizá-la da melhor forma possível, ficando perto dela, segurando nas mãos e dizendo que vai ser rápido e logo ela vai ter o bebê. No meu plantão, tudo o que precisamos: uma ajuda a outra. O que a enfermeira pede nós estamos de acordo. Quando vemos que a conduta dela está coerente, fazemos sempre, tentando ajudar por causa do cuidado com a mãe e o RN. As equipes são bem entrosadas, procuramos sair daqui sabendo que está tudo certo que não lesou ninguém. A instituição quer isso de nós, saber que demos o melhor. Entre os médicos o contato é muito rápido, principalmente o neonatologista. Ele vem, olha o RN e vai embora. OGO, menos ainda: eles vêem quando são solicitados, porque tem as enfermeiras obstetras, mas o contato entre nós é bom. Aqui no CPN, por ser maternidade, tem poucos leitos, às vezes fica lotado e fica mãe sentada em cadeira. Isso não é correto. Agora estamos sem leito no alojamento conjunto, a mãe tem que ficar aqui na maca. É uma maca estreita, temos que colocar o RN junto com ela e o bebê pode cair. Nós temos vários leitos nos AC. O CPN é pequeno. Nunca usei a sala da fisioterapia e agora ela está sendo usada como GO. Fica fora de mão deixar as mães naquela sala para trazer na hora do parto andando ou até na cadeira de roda. O espaço é muito longo, se concentrasse tudo aqui perto da sala de parto seria melhor. Quando entrei, fui treinada pelos colegas de trabalho. Eu já acho que quando você entra deveria ser treinado por uma equipe de educação continuada, para que quando desse orientações de como funciona, desse treinamento e uma educação continuada sempre, por mais que ficasse repetitivo. Protocolo, não vi aqui ainda. Acho que tudo funciona através de um protocolo, dizendo como é para ser feito, mas eu não vi isso ainda, faço de um jeito, outros fazem de outros jeitos e assim vai indo. Quer dizer, não tem uma continuidade de cuidado, começo de um jeito outros terminam de outro. Com a parte administrativa não temos muito contato, mais com a supervisão. Para mim, uma boa assistência é estar sempre do lado da mãe no momento dificil, sabendo que você pode ajudar. Ser humano tratando como se fosse um parente seu, como se fosse você mesmo, porque depois ela vai lembrar de você e vai dizer "nossa como ela me ajudou, como foi minha amiga”. Porque, quando entramos em um hospital é ruim para qualquer pessoa. Então, ela precisa de um apoio. Fico satisfeita quando ajudo e a mãe me dá um sorriso, agradece, pede para ficar junto, acompanhar no parto, quando ela se sente tranquila. Estou aqui há 2 anos e 2 meses. Gosto muito daqui, principalmente de estar no RN. Faço o que gosto, gosto de estar perto desses RN e é isso que quero para a minha vida. Gosto de estar aqui; em resumo, nosso único problema realmente é a falta do protocolo, da educação continuada”. 
TE 4: "Trabalho aqui há dois anos. Entrei por intermédio de uma amiga. É bom trabalhar aqui quando tudo ocorre bem, mas tem pacientes que precisam do GO e, às vezes, demora. Tem vezes que seguram as mulheres doze ou quatorze horas para depois dizer que vai ser cesárea. Acho isso errado, precisam dizer logo se vai ser normal e fazê-lo, ou cesárea e fazê-lo. Acho mais interessante trabalhar com o RN. Tem plantão aqui que você chega de manhã e, quando vai embora, sai extremamente pesada. Aqui não tem organização, não colocam um protocolo para que saibamos o que temos que fazer, resolvem na chefia, mas nós não ficamos sabendo de nada. Aquele protocolo com dez passos eu pedi para a médica para colar na parede, porque falam que o que está pendente aqui é o quarto passo, mas não é somente ele, todos os dez estão faltando. O cuidado deve começar da porta e ser feito o ano inteiro. Não tem comunicação entre a chefia, a médica; estamos muito distante. A sala de parto humanizado só é aberta quando o alojamento conjunto está cheio. Quando lá não tem mais vaga. Tem dias que o pré-parto fica cheio, a recuperação fica cheia e o corredor também, ficamos com oito mães no corredor, não tendo onde ganhar bebê e não podendo liberar visita. Isso acontece muito aqui. O último curso que fiz aqui foi o de aleitamento materno, só esse, não me lembro de outro, porque o foco é para neo e a gente não entra no foco. Dizem que não temos necessidade. Quando entrei aqui não teve ninguém que me treinasse, o que aprendi foi pelo meu interesse, as coisas aqui estão desfocadas; no meu plantão tem cinco pessoas só, o correto seria: duas no pré, duas no parto normal e duas na UTI. Não tem. Já trabalhei aqui com duas. Quanto aos recursos, o que funciona mais é o banho, mas tem mães que não aceitam o banho, ai temos que conscientizá-las da necessidade de que ela faça algumas coisas para o próprio bem. A bola já não é muito utilizada, muitas querem cesárea não querem parto normal; muitas não querem fazer as coisas e não tem como forçá-las. Quando a paciente está com uma boa dilatação, nós já avisamos a enfermeira, mas tem vezes que elas não acreditam em nós, então acontece de muitas vezes não dar para fazer os passos certos, pois a mãe já ganha no pré, os passos certos são levá-la para a sala de parto, deitá-la na mesa, fazer a assepsia, a anestesia e a Episio. Agora, quando algum desses passos atrasam, dá problema, tem muitas enfermeiras que não gostam de fazer o Episio e acontece de algumas crianças nascerem muito grande e sofrerem fraturas. Uma boa assistência seria receber a mãe e ter o apoio das enfermeiras a respeito do que você vai fazer; a enfermeira partejar. Para uma boa assistência tem que estar toda a equipe presente. Saio daqui satisfeita quando a mãe entra e tudo dá certo, quando você vê que fez seu serviço direito e a mãe saiu daqui contente. Minha experiência aqui não tem sido muito boa. Não sei se é isso o que quero". 


\section{OS ESQUEMAS CONCEITUAIS, OS DESCRITORES CULTURAIS E O SUBTEMA CULTURAL}

\section{DC1 - Satisfação com o trabalho desenvolvido}

-Temores iniciais na chegada à instituição relativos ao desenvolvimento da assistência

Falta de experiência no contexto hospitalar

Desconhecimento do trabalho no CPN

Desconhecimento da equipe de trabalho

- Possibilidade de prestar assistência considerada adequada

Características da assistência prestada

- Estabelecimento de comunicação interpessoal

- Tratamento personalizado

- Acolhimento oferecido às gestantes

- Trabalho em equipe

- Existência dos insumos necessários à assistência

- Atendimento às necessidades da parturiente

- Domínio do conhecimento técnico

- Promoção de ambiente familiar

- Estabelecimento de vínculo com as gestantes

- Protagonismo do parto atribuido às gestantes

- Prestação de assistência ao recém-nascido (RN)

Maior identificação com o cuidado do $R N$

- Valorização do trabalho desenvolvido pelas fisioterapeutas

- Métodos não-farmacológicos de alívio da dor

Banho terapêutico

Bola suiça

- Cumprimento pleno do papel profissional

- Assistência ao parto com desfecho satisfatório 
$\mathrm{Na}$ chegada ao hospital apresentaram temor relativo ao desenvolvimento da assistência na Maternidade. Estes temores se manifestaram pela falta de experiência no contexto hospitalar, pois já haviam trabalhado em outros tipos de serviços, como asilos, mas a Maternidade foi o primeiro contato com o modelo hospitalar; pelo desconhecimento do trabalho desenvolvido no CPN, por se tratar de um perfil novo de assistência, tinham total desconhecimento das práticas dos profissionais dentro do $\mathrm{CPN}$, pois, durante a formação tecnológica, não tiveram contato com este modelo; e pelo desconhecimento da equipe de trabalho, que era uma incerteza para elas, pois não sabiam se a equipe seria receptiva e até mesmo colaborativa com as dificuldades e as dúvidas que poderiam apresentar.

"No começo tinha muito medo, mas, com o tempo, as pessoas me receberam muito bem, me ensinaram. Hoje faz três anos que estou aqui, o pouco que sei foram as outras colegas que me ensinaram". (2)

"Não tinha experiência em hospital. Quando entrei aqui foi tudo novo, porque não conhecia as pessoas com quem ia trabalhar, o que ia fazer no CPN, mas todos me trataram bem e me ajudaram". (4)

As profissionais relataram que estes temores foram desaparecendo com o tempo e com o auxílio dos integrantes da equipe do $\mathrm{CPN}$, que prestaram uma ótima recepção e acolhimento e também ensinaram quanto ao trabalho que seria desenvolvido.

Quanto ao trabalho desenvolvido, todas as técnicas apresentavam maior identificação com o cuidado ao recém-nascido. $O$ interesse e a satisfação na assistência estão ligados mais ao cuidado ao $\mathrm{RN}$ do que à parturiente. Uma delas, ao entrar na Maternidade, foi direto para a UTI Neo, pela identificação com o RN. Outra relatou ter ficado dois anos no Alojamento Conjunto, mas desejava ficar o mais perto possível do $\mathrm{RN}$ e, por isso, teve o interesse de trabalhar dentro do CPN. $\mathrm{Na}$ observação participante pude perceber que na assistência elas realmente se dedicam mais a prestar cuidados ao $\mathrm{RN}$ do que à mãe. 
"Minha experiência aqui tem sido ótima, tenho aprendido muito. Gosto muito de lidar com crianças pequenas”. (4)

"Entrei aqui no Alojamento Conjunto, fiquei dois anos, mas queria ficar mais próxima ainda do $R N$ (...). gosto de estar perto desses RN e é isso que quero para minha vida”. (3)

"Acho mais interessante trabalhar com o $R N$ do que com a parturiente...”. (1)

Referiram como ótimas suas experiências de trabalho no Amador Aguiar porque tinham satisfação com o trabalho que desenvolviam na instituição. Esta satisfação estava ligada principalmente ao ambiente do CPN, que propiciava a possibilidade de prestar assistência considerada adequada, com a devida atenção às necessidades da parturiente, sejam físicas ou emocionais.

\footnotetext{
"Gosto muito de onde estou trabalhando porque gosto de lidar com o ser humano, de trabalhar o lado psicológico, procuro ter paciencia, brincar, ver a necessidade da paciente desde quando ela chega". (2)
}

A satisfação com o trabalho também era adquirida quando a assistência ao parto teve desfecho satisfatório. O desfecho satisfatório era quando conseguiam prestar o atendimento que consideravam adequado, sem cometer erros, com competência, e a mulher, ao final, fica satisfeita e contente pela forma com que foi atendida por elas.

"fico satisfeita quando a mãe entra no CPN e dá tudo certo, quando vejo que fiz meu serviço direito e a mãe saiu daqui contente". (1)

No Centro de Parto outro ponto que trazia satisfação era a possibilidade de trabalhar com a humanização. Acreditavam que para a humanização da assistência era necessário ser cordial com a parturiente, sendo educadas, prestativas e tendo uma forma de amorosa no falar; precisavam estar atentas às queixas da parturiente, porque, se não houvesse nenhuma enfermeira perto, tinham que prontamente informá-las; tinham que estar ao lado da mulher e tranquilizá-la no momento do desconforto do trabalho de parto. 
"Humanização, para mim, é ser cordial com a mãe. Ficar sempre atenta com as queixas dela e dar apoio psicológico. Pela minha experiência, sei que ninguém está acostumado a passar por uma dor dessas. Então, fico sempre tranquilizando a mãe. Tentamos sempre tranquilizá-la da melhor forma possível, ficando perto dela, segurando nas mãos e dizendo que vai ser rápido e que logo vai ter o bebê". (3)

Dentro do Centro de Parto, o tratamento direcionado à gestante era diferenciado. Existiam algumas crenças relativas à "boa assistência" à parturiente que permeavam a prática das profissionais. Uma delas dizia respeito ao tratamento personalizado que o profissional devia prestar à mulher, porque cada uma era um ser único que possuía reações diferenciadas no trabalho de parto. Enquanto, algumas mulheres podiam não referir dor alguma, outras apresentam dor aguda. Referiram a importância de respeitar os limites de cada mulher, dando atenção às questões emocionais, lembrando de prestar também uma assistência psicológica no trabalho de parto.

\footnotetext{
"Uma boa assistência é enxergar a paciente como um ser humano, porque cada um tem um limiar de dor. Tem pacientes que são mais tranquilas, outras não, temos que saber respeitar os limites, prestar uma boa assistência psicológica. Não somente fazer uma medicação. Temos que aprender a ouvi-la”. (2)
}

Consideravam também a importância do trabalho em equipe para o desenvolvimento de uma assistência de qualidade. Julgavam que deveria haver entrosamento e um bom relacionamento entre as enfermeiras e as técnicas de enfermagem. As enfermeiras devem cumprir o seu papel de partejar a mulher neste processo e apoiar as técnicas em sua conduta.

\footnotetext{
"Uma boa assistência seria receber a mãe e ter apoio das enfermeiras a respeito do que você vai fazer, a enfermeira partejar. Para uma boa assistência tem que estar toda a equipe presente". (1)
}

\section{$\mathrm{O}$ atendimento das necessidades da parturiente e o oferecimento de}

acolhimento para proporcionar sensação de segurança à gestante foram considerados aspectos fundamentais. Segundo a avaliação delas, o profissional deve se colocar no lugar da parturiente, de modo a entender que é um momento difícil para ela. A mulher encontra-se num hospital que não possui o conforto e a liberdade de sua 
casa; desta forma. cabe ao profissional apoiá-la para tornar aquele momento o melhor possível.

"Para mim, uma boa assistência é sempre estar ao lado da mãe no momento difícil ,sabendo que você pode ajudar. Ser humano tratando como se fosse seu parente, como se fosse você mesmo (...) porque, quando entramos num hospital, é ruim para qualquer pessoa. Então, ela precisa de um apoio, e quando você está ajudando elas gostam disso, ficam felizes e gostam de ser cuidadas". (3)

Como citado anteriormente, como um preditivo da humanização, a vigilância foi referida como essencial na prestação do cuidado ideal para que não ocorra nenhuma fatalidade. Estar atenta às reações da mãe é imprescindível para protegê-la de alguma intercorrência séria, pois as condutas podem ser realizadas com mais antecedência se houver a indicação de alguma complicação clínica.

“... uma boa assistência é aquela que é atenta a tudo que acontece com a mãe, porque qualquer descuido pode ser fatal. Em resumo, temos que dar toda a atenção e ficar atentos". (4)

Referiram que o Centro de Parto Normal do Hospital e Maternidade Municipal Amador Aguiar apresenta algumas características principais na atenção à parturiente. Estas características, da assistência desenvolvida na Maternidade, envolviam a prestação dos cuidados iniciais e essenciais. Relataram que cabe a elas puncionar veias, instalar soros, oferecer os primeiros cuidados à parturiente. Logo, são inevitavelmente as primeiras a terem contato com a parturiente dentro do CPN. Este contato inicial era de grande importância, porque neste momento elas tinham que promover o acolhimento e transmitir segurança à mãe, uma vez que chegavam nervosas e assustadas. Na chegada ao pré-parto, as mulheres apresentavam também muitas dúvidas referentes ao parto e quanto a política institucional, desta forma cabia a elas responder as dúvidas que as mulheres apresentam na chegada.

"Algumas têm muito medo, procuramos acalmá-la, outras têm muitas dúvidas, outras nem sabem o que vai acontecer. Então vamos conduzindo tudo isso". (2)

"Quando a mãezinha chega, tentamos acalmá-la porque isso é prioridade. Ela chora, chega nervosa, mesmo sendo o 
quinto filho, temos que acalmar e fazer os cuidados essenciais”. (4)

Neste CPN eram utilizados métodos não-farmacológicos de alívio da dor. O mais utilizado era o banho de imersão. Quanto à bola suíça e à deambulação, eram pouco utilizados. Estes métodos eram positivos para a progressão do trabalho de parto. Referiram que algumas mulheres não aceitavam alguns desses métodos e não colaboravam porque desejam a cesariana e não o parto normal.

"O que é mais usado aqui é o banho, a caminhada; a bola nem tanto. Quando você faz esse trabalho de fisioterapia acaba ajudando no trabalho de parto. É uma forma de acelerar o processo sem agressividade e a paciente consegue ter um resultado melhor. Quando a paciente não quer, não forçamos, mas a incentivamos." (2)

“... o que funciona mais é o banho, mas tem mães que não aceitam o banho, então temos que conscientizá-las da necessidade de que ela faça algumas coisas para o próprio bem, a bola já não é muito utilizada. Muitas querem cesárea não querem parto normal, muitas não querem fazer as coisas e não tem como forçálas". (1)

O contato da equipe de enfermeiros e técnicos de enfermagem com os médicos obstetras e principalmente com os médicos neonatologistas era muito rápido dentro do CPN. Esta presença restrita do médico obstetra e do médico neonatologista devia-se ao fato de somente irem ao Centro de Parto quando solicitados pela enfermagem.

\footnotetext{
"Entre os médicos o contato é muito rápido, principalmente o neonatologista. Ele vem, olha o $R N$ e vai embora. O GO, menos ainda: eles veem quando são solicitados, porque tem as enfermeiras obstetras..." (3)
}

Referiram que, conforme a política hierárquica do $\mathrm{CPN}$, eram subordinadas aos enfermeiros e, desta forma, sempre procuravam seguir as orientações dos enfermeiros, quando estas eram coerentes com o atendimento de qualidade.

"O que a enfermeira pede de nós. estamos de acordo. Quando vemos que a conduta dela está coerente, fazemos; sempre tentando ajudar, por causa do cuidado com a mãe e o RN. As equipes são bem entrosadas, procuramos sair daqui sabendo que está tudo certo; que não lesou ninguém." (2 3) 
DC2 - As dificuldades enfrentadas para desenvolver a assistência

- Ausência de protocolos assistenciais

Falta de unanimidade nas condutas

Existência de filosofias assistenciais diferentes

- Quantidade insuficiente de funcionários

- Relativas ao espaço físico

Reduzida quantidade de leitos no CPN e no alojamento conjunto

Subutilização dos recursos do CPN

Suites de parto sem utilização

- Ausência de treinamento em serviço

- Sobre o relacionamento com membros da equipe

Subordinação aos enfermeiros

- Existência de divergências entre as condutas médicas e enfermagem

- Ausência de comunicação entre a chefia administrativa e os profissionais 
Relataram que neste Centro de Parto Normal existiam inúmeras dificuldades para o desenvolvimento da assistência e que faziam todo o possível para superá-las. Porém, por mais satisfeitas com a assistência que prestavam, o cotidiano neste Centro de Parto era muito difícil devido ao esforço que desenvolviam para a superação das dificuldades.

Valorizavam a prática da humanização na assistência, mas referiram que nem tudo que era preconizado era possível de ser realizado nesta Maternidade; por isso faziam o que estava ao seu alcance.

\footnotetext{
"Acho legal a questão da humanização, às vezes não dá para fazer tudo que tem que ser feito. Então faço o que posso”. (4)
}

Um grande impeditivo para que as vertentes preconizadas pela humanização fossem efetivamente implementadas dizia respeito à ausência de protocolos assistenciais para nortear a prática profissional. A ausência desses protocolos provocava a falta de continuidade no cuidado e de unanimidade nas condutas da equipe multiprofissional. Havia desorganização e confusão acerca da prática, porque cada profissional decidia, conforme suas próprias experiências e pelos conhecimentos adquiridos durante a formação, qual era a melhor atitude a ser empregada frente às diversas situações recorrentes no CPN. A assistência ficava prejudicada, porque não havia uma linha norteadora para a continuidade do cuidado e a cliente era vitimada, pois era atendida de diversas formas no período de sua internação. Por fim, a equipe desenvolvia um conflito, por discordância de condutas, que poderia ser evitado com a existência do protocolo.

"Protocolo não vi aqui ainda. Acho que tudo funciona através de um protocolo dizendo como é para ser feito, mas não vi ainda. Faço de um jeito, outros fazem de outro. Quer dizer, não tem continuidade no cuidado. Deveria ter esse protocolo”. (3)

"Aqui não tem organização, não colocam um protocolo para que saibamos o que temos que fazer; resolvem na chefia, mas nós não ficamos sabendo de nada. Aquele protocolo com os dez passos do Hospital Amigo da Criança eu pedi para a médica para colar na parede, porque falam que o que está pendente aqui é o quarto passo, mas não é somente ele: todos os dez estão faltando". (1) 
Outra dificuldade apontada era relativa à alta demanda da Maternidade. O número excessivo de atendimentos, aliado à falta de espaço físico, provocava, muitas vezes, a superlotação do CPN que ficava com até oito mães no corredor durante muitas horas e sem a possibilidade de receberem visitas. A demanda excessiva deixava também os profissionais sem espaço para trabalhar da forma adequada, fazendo com que as mulheres recebessem uma assistência de má qualidade.

"Tem dias que fica cheio o pré-parto, a recuperação e o corredor também. Ficamos com oito mães no corredor, sem ter onde ganhar bebê e não podendo liberar visita. Isso acontece muito aqui". $(1,4)$

"Tem dias que aqui está cheio e não tem espaço para a mãe e nem para o acompanhante. Com muita gente também não temos espaço para trabalhar. A mãe fica, muitas vezes, sentada esperando". (4)

\section{A reduzida quantidade de leitos no CPN e no alojamento conjunto}

deixava as mães em condições precárias, tendo que esperar por um leito sentadas, enquanto seu acompanhante fica sem lugar para se acomodar.

"No CPN, por ser Maternidade, tem poucos leitos; às vezes fica lotado e fica mãe sentada em cadeira. Isto não é correto. Hoje mesmo estamos sem leitos no Alojamento Conjunto, a mãe tem que ficar aqui na maca. É uma maca estreita, temos que colocar o RN junto com ela e o bebê pode cair. Nós temos vários leitos no AC, mas o CPN é pequeno”. (3)

Esta alta demanda do CPN, aliada à quantidade insuficiente de funcionários, prejudicava muito a assistência prestada. Os profissionais referiam não dar a assistência com qualidade também pelo número reduzido de funcionários, mas não havia outra opção. Por isso, achavam necessário o aumento do quadro de funcionários, por meio de novas contratações e o oferecimento de melhores condições de trabalho para a mudança desta realidade.

"Tem dias que são bem dificeis, porque o quadro de funcionários é reduzido. Não conseguimos dar aquela assistência para a mãe nem para o bebê, mas temos que olhar e fazer". $(1,4)$ 
"A demanda aqui é grande; deveriam trazer mais gente para trabalhar e dar mais condições de trabalho”. (4)

O número reduzido de funcionários também provocava subutilização dos recursos do CPN. As suítes de parto ou Centro Humanizado estavam fechadas desde sua inauguração.

"Mas ainda acho que os recursos disponíveis poderiam ser mais explorados. Não são pela falta de funcionários. Se fossemos abrir o Centro Humanizado teríamos que disponibilizar mais funcionários. Mas aqui se faz tudo o que pode". (2)

Acreditavam que os motivos para que as suítes de parto estivessem inutilizadas fossem a carência de funcionários e a distância delas do pré-parto. Relataram que o Centro Humanizado só era utilizado quando não havia vagas no Alojamento Conjunto ou quando outro setor estava com algum tipo de problema, como acontecera com a GO.

\footnotetext{
"Nunca usei a sala da fisioterapia e agora ela está sendo usada como GO. Na sala, fica fora de mão deixar as mães para trazer na hora do parto andando ou até na cadeira de rodas. $O$ espaço é muito longo; se concentrasse tudo aqui perto da sala de parto seria melhor". $(1,2,3)$
}

Alguns profissionais estavam desejosos para a reabertura do Centro Humanizado e diziam que não tinham dificuldades de trabalhar nele. Diziam que sua reabertura seria uma solução para a falta de leitos e a superlotação do CPN.

\footnotetext{
"Por isso que tinham que abrir o CPN, já que tem. Não tem nada que impeça-os de abri-lo. A não ser a falta de funcionários. Acho que deveria abrir, porque tem gente para trabalhar na área. Ou talvez a prefeitura não tenha condições; porque funcionário tem sobrando". (4)
}

Neste Centro Humanizado existia uma banheira. Como havia apenas uma banheira disponível para todas as parturientes, referiram que ela não era utilizada por questão de higiene, por haver perdas de líquido e sangue.

"A banheira não é usada por questão de higiene, para não colocar uma paciente que vai perder líquido, perder sangue”. (2) 
Relataram a ausência de treinamento em serviço, tanto na chegada à instituição quanto no decorrer dos anos. Referiram a importância de serem instruídas no processo de contratação quanto à filosofia e às práticas assistenciais do CPN e a necessidade de haver uma equipe de educação continuada para reciclagem do conhecimento, sempre que possível.

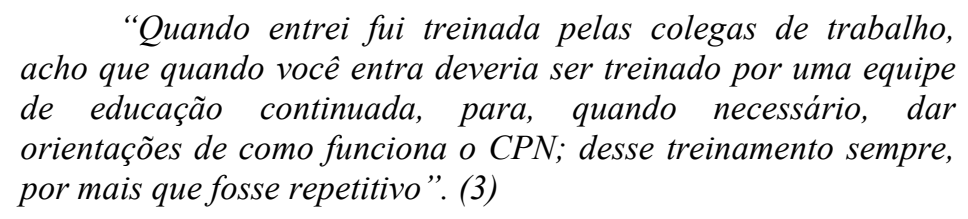

Relataram que se lembravam de ser oferecido na instituição apenas Curso de Aleitamento Materno, porque acreditavam que o foco da Maternidade era a Neonatologia e não a Obstetrícia.

"Quando entrei aqui não teve ninguém que me treinasse, o que aprendi foi pelo meu interesse. (...) O último curso que fiz aqui foi de Aleitamento Materno só esse, não lembro de outro, porque o foco é para neonatologia e nós não entramos no foco”. (1)

Acerca do relacionamento com membros da equipe, havia a subordinação aos enfermeiros obstetras, o que muitas vezes gerava dificuldades, pela existência de divergências entre as condutas médicas e de enfermagem. Referiram que estas divergências acarretavam em confusão para elas, porque não sabiam qual hierarquia seguir. Por exemplo, quando o médico neonatologista instruía para trazer o RN para ele, enquanto a enfermeira dizia para deixá-lo em cima da mãe.

“...sou subordinada. Se a enfermeira vem até aqui e tem a conduta de colocar o bebê em cima da mãe, respeito. Mas quando tem a intervenção de um médico, que diz para trazer o bebê, não sei o que fazer". (2)

Relataram a ausência de comunicação entre a chefia administrativa e os demais profissionais. Existia distanciamento e, por conseguinte, falta de comunicação entre os integrantes da equipe profissional

"Não tem comunicação entre a chefia, os médicos e nós. Estamos muito distantes". (1) 
No imaginário acreditavam que a realização de episiotomia deveria ser de rotina nos partos. Sua não realização estava diretamente ligada à fratura de clavícula nos RN.

“...tem muitas enfermeiras que não gostam de fazer Episio, $e$ acontece de algumas crianças nascerem muito grandes $e$ sofrerem fraturas". (1)

Acreditavam que, no momento que o trabalho de parto da mulher se prolonga por várias horas, deveria haver uma intervenção mais direta por meio da realização de cesariana. Percebi, na observação participante, a falta de compreensão dessas profissionais a respeito da fisiologia do parto.

"Tem vezes que seguram as mulheres doze ou quatorze horas para depois dizer que vai ser cesárea. Acho isso errado, precisam dizer logo se vai ser normal e fazê-lo, cesárea e fazê-lo”. (1)

STC 2: Fazendo o que é possível: satisfação com a assistência que é prestada mediante superação de muitas dificuldades 


\subsection{OS MÉDICOS OBSTETRAS, SUAS CARACTERÍSTICAS, SUAS NARRATIVAS, O ESQUEMA CONCEITUAL E O SUBTEMA CULTURAL}

A equipe de médicos está disposta conforme quadro 3 abaixo:

Quadro 3 - $\quad$ Os médicos Obstetras e suas características. São Paulo, 2011

\begin{tabular}{|c|c|c|c|c|c|c|c|c|c|}
\hline Entrevista & Idade & Naturalidade & Religião & Estado Civil & Paridade & $\begin{array}{l}\text { Maior Grau } \\
\text { Escolaridade }\end{array}$ & $\begin{array}{c}\text { Tempo de } \\
\text { experiência } \\
\text { profissional } \\
\text { na área }\end{array}$ & $\begin{array}{l}\text { Tempo na } \\
\text { Instituição }\end{array}$ & $\begin{array}{c}\mathrm{N} \text { de } \\
\text { Empregos }\end{array}$ \\
\hline \multicolumn{10}{|c|}{ INFORMANTES-CHAVE } \\
\hline MO 1 & 37 & Amazonas & Católica & Casada & 2 & Especialização & 2000 & 6 anos & 3 \\
\hline MO 2 & 28 & São Paulo & Católica & Casada & - & Especialização & 2007 & 3 anos & 2 \\
\hline \multicolumn{10}{|c|}{ INFORMANTES GERAIS } \\
\hline $\mathrm{MO} 3$ & 57 & São Paulo & Católico & Divorciado & 5 & Especialização & 1992 & 1 ano & 2 \\
\hline MO 4 & 29 & São Paulo & Espírita & Casada & 2 & Especialização & 2006 & 2 anos & 2 \\
\hline MO 5 & 30 & São Paulo & Católica & Solteira & - & Especialização & 2007 & 1 mês & 2 \\
\hline MO 6 & 30 & São Paulo & - & Solteira & - & Especialização & 2008 & 2 anos & 2 \\
\hline
\end{tabular}

Nesta pesquisa, observa-se que os 6 médicos obstetras que colaboraram tinham entre 28 e 57 anos, com média de 35 anos; cinco deles eram naturais de São Paulo e um do Amazonas. Quando à paridade, três dos médicos tinham filhos, sendo a média de um filho. Três eram casados, duas solteiras e um divorciado. Todos os médicos obstetras tinham especialização em obstetrícia.

Quanto à religião, quatro declararam ser católicos, um espírita e uma não referiu ter religião. Quanto ao ano de término da graduação, o período foi de 1992 a 2008. Quanto ao tempo na instituição, variou de 1 mês a 6 anos, com média de 2 anos. A média de empregos dos médicos obstetras foi de 2 empregos. 


\section{As suas narrativas}

MO 1: "Trabalho há seis anos e meio na Maternidade. Quando cheguei, não tinha parto humanizado. Fui até bem resistente com relação a isso, pois indaguei como conduziríamos? Seria possivel com uma população carente? Essa população estaria preparada para estar dentro de um Centro de Parto? Será que ela ia facilitar a tua vida ou dificultá-la? Mas depois percebi que era uma questão de diálogo, de explicar, orientar. Aqui é a maternidade de alto risco da região. Então, chegam pacientes de alto e baixo riscos. Estas pacientes são atendidas no atendimento geral, no PS da G.O. e fazemos uma triagem delas. As que forem graves e precisam de internação, de algum acompanhamento obstétrico, ficam internadas. Existe uma enfermaria de patológicas que elas se mantêm lá e tem um médico que supervisiona. As pacientes que estão em trabalho de parto são internadas e acompanhadas conjuntamente por nós e as enfermeiras obstétricas. Então, ou ela interna em trabalho de parto e vai para o Centro de Parto Normal, sob a supervisão das enfermeiras obstétricas e dos médicos obstetras, ou ela interna com alguma intercorrência e vai para o CO, na supervisão do médico obstetra que realiza a cesárea. O entrosamento é necessário para que tudo aconteça, mas não é fácil lidar com todo esse processo, porque você tem uma enfermeira obstetra supervisionando diretamente o parto, porque nós não conseguimos ficar todo o tempo dentro do CPN. Então, tem as pacientes internadas e cada uma delas com acompanhante precisando de supervisão da enfermeira, que está lá e vai acompanhar o trabalho de parto e também tranquilizar o acompanhante, para que colabore, porque se ele também apresentar algum tipo de ansiedade frente ao que está acontecendo, vai dificultar um pouco o desenvolvimento. Acima de tudo isso, quando elas sentem que algo está errado, quando o partograma começa a apresentar algum sinal de distócia, elas nos chamam para observar isso. Dentro do possivel, vamos supervisionando mesmo sem elas chamarem, porque tudo que acontece lá dentro é de responsabilidade médica. Temos que ficar atentos ao que acontece, pois vamos responder ou resolver alguma intercorrência que aconteça. Essa questão da enfermeira obstetra dentro do Centro de Parto para o médico é nova, porque nenhum médico tem formação ou adaptação para esse tipo de trabalho na residência. Ninguém se forma com enfermeiro obstetra em nenhum lugar. Na verdade é um distanciamento que se vê: quanto mais próximo dos serviços acadêmicos, menos enfermeiras obstétricas e vice-versa, porque é uma situação economicamente mais fácil para o hospital. O que tecnicamente não é tão ruim, porque tem pessoas com boa formação que conseguem fazer um bom trabalho, mas nem todas. Assim como também vemos da parte médica. Este trabalho não é ruim, mas tem que ser muito acoplado ao obstetra porque se tem uma enfermeira obstetra, que avisa na hora certa o que está acontecendo, funciona e ela não é mal vista a pelos médicos. Mas se tem alguém descuidada, que não vê BCF de hora em hora, que não vai olhar a paciente e a comunicação é falha, tudo vai mal. Temos que falar a mesma língua. Elas têm que saber com tantos centímetros abre o partograma, tocar de hora em hora e escrever na mesma língua do médico, porque ele sabe o que tem que ser feito. $O$ dia a dia se constitui no atendimento dessas pacientes, na triagem e nos seus seguimentos. Todas as pacientes que são internadas em trabalho de parto têm direito a um acompanhante de escolha, o parceiro, a mãe ou alguém mais próximo. Eles podem fazer o seguimento de todo o trabalho de parto com a paciente, 
eles entram na sala de parto e acompanham o nascimento do RN. O projeto inicial do CPN previa o uso da banheira, tinha uma equipe de fisioterapeutas que atuava junto, até tem essa equipe ainda, mas esporadicamente. Elas ajudavam bastante, pois orientavam, aconselhavam a questão mecânica do parto, colaboravam com o aspecto psicológico porque estão próximas. Isso dá conforto e acolhimento. Na prática, não fazemos o uso desses recursos, não tem banheira, nada. Acho que é porque temos um fluxo grande de pacientes e não dá para manter uma assepsia adequada do ambiente para que todos possam usufruir. E os recursos que temos são precários, os sonares não são tão eficientes assim, não tem um sonar para cada paciente. Mas, dentro do possível, flui de maneira favorável em condições assépticas. Uma boa assistência, para mim, é fazer o diagnóstico correto, na hora certa e fazer uma supervisão adequada dentro do que é preconizado pelo Ministério da Saúde e pelos preceitos obstétricos que conhecemos. É um trabalho multidisciplinar. A implantação do Centro de Parto foi satisfatória, apesar de que a principal mudança não deveria ser só aqui, mas sim no prénatal,o acompanhante deveria estar presente também. O marido e a sogra precisam participar e ouvir as orientações porque teoricamente este médico orienta sobre o trabalho de parto. Se chegassem sabendo o que vai acontecer, seria muito mais fácil. Não acontece esse tipo de orientação nem para a paciente, quanto mais para o acompanhante. Fico satisfeita quando as coisas dão certo, o desenrolar é adequado, a mãe sai saudável. Os maiores problemas que vemos não são em relação ao parto, mas primeiro ao pré-natal, pois se ele é bem conduzido, mesmo que tenha riscos, desenrola da forma certa. É satisfatório quando conseguimos conduzir, o bebê nasce bem. A maioria das autoridades políticas não se preocupa com o pré-natal de baixo-risco, tanto que começa pela enfermagem, o que acho um pouco errôneo. Tem que começar com um diagnóstico médico correto, porque, se começa com um diagnóstico errado, e ele é conduzido errado: complica tudo. Tenho muito a crescer e a cada dia surgem situações extremamente novas. A obstetrícia é sempre uma caixinha de surpresas, nunca se sabe o que vai acontecer. A experiência é boa, mas acho que a politica de saúde poderia ser melhor. Parece que alguma coisa não chega, você quer fazer um trabalho, mas sempre algo está bloqueando. As políticas precisam ser melhoradas, priorizar o que deve ser priorizado. Nós só queremos condições de trabalho. Não queremos supersalários. Só queremos desempenhar a função do jeito que tem que ser feita. Sem precisar de muita coisa. Mas tudo é válido. Tudo é aprendizado e continuamos aprendendo sempre”. 
MO 2: "Escolhi fazer obstetrícia no terceiro ano da faculdade, pois entrei querendo fazer geriatria. Vim trabalhar no Amador por intermédio de um amigo e desde então me apaixonei por aqui. Mesmo com todos os problemas que esse hospital ainda tem, é um lugar muito rico para quem quer ver as coisas, é um hospital que tem um volume muito grande e é muito bom para trabalhar. A parte de internação das pacientes nos fazemos o seguinte: as atendemos na porta, examinamos e se realmente tiver tudo para ser um parto normal vamos encaminhar ela para o CPN. Claro, sempre tentando explicar para ela tudo o que vai acontecer, como vai permanecer a dor, mas acho que essa assistência tinha que vir lá do pré-natal, porque as pacientes chegam aqui muito inseguras, porque vão ter o bebê, inseguras quanto às dores e ninguém trabalhou o psicológico delas no pré-natal. Precisa explicar para ela como é que as coisas vão evoluir e como aqui tem um volume muito grande, infelizmente a gente falta nesse sentido; porque temos que explicar, mas deveria ser explicado mais. A partir do momento que ela vai para o CPN é a participação da enfermeira obstetriz intensa em cima dela. Nós trabalhamos com uma equipe maravilhosa, que fica "partejando" em cima mesmo, e na hora o parto era lindo, tranquilo, sereno, ajudando. A participação do acompanhante é muito boa, alguns influenciam negativamente, mas, na maioria, é muito bom, querendo ou não o plantão de obstetrícia é uma equipe multidisciplinar. É um caso que a gente discute entre os médicos, entre as enfermeiras, entre as auxiliares, entre os técnicos, com todo mundo e se for uma equipe que se entrosa bem, pode ter certeza de vai nascer bem, a mãe vai evoluir bem, vai dar tudo certo, se tiver cuidado. A equipe que nós trabalhávamos era uma equipe maravilhosa, eles chegavam e diziam que não iria nascer e podíamos confiar, mas creio que a assistência primordial é aquela que você fica com a paciente os nove meses no pré-natal, se ela chegasse aqui sabendo tudo o que irá acontecer, ela não diria que quer uma cesárea, pois se ela soubesse o risco que é uma cesárea, elas iriam brigar com a gente por um parto normal; e é isso que falta explicar para ela desde o começo como as coisas vão acontecer; se virar cesárea por que acontecerá. Quanto aos critérios de internação, nós usamos o critério absoluto de cesárea, vai ser cesárea, no caso de já ter tido duas cesáreas ou mais, examinamos o líquido da paciente, o tamanho da barriga, examinamos se está indo tudo bem, se não está com contração uterina forte, depois vamos examinar junto o cardiotoco e ver se realmente tem tudo para ser um parto normal, se tiver tudo para ser tranqüilo, vai para o CPN. Se ficarmos inseguros em algum momento, em alguma coisa, ai investigamos mais para ver se vai ser uma cesárea, ou se ficar tranquilo encaminhamos para o CPN. Para mim, uma boa assistência é um prénatal bem feito, bem instruido, é uma paciente chegando aqui sabendo tudo o que vai acontecer com ela e se não souber tudo, saber pelo menos uma grande parte, depois a partir do momento em que ela chegar aqui sentir firmeza na equipe inteira, ver uma equipe bem estruturada para não ter atrito entre a equipe em quando for para o CPN ser assistida, estimulada e gostar de tudo aquilo, achar tudo necessário e importante para aquele momento. O primordial é saber o que vai acontecer com ela, pois as pessoas ficam inseguras com qualquer coisa nova e se é uma coisa que ela imagina que vai acontecer, já fica mais tranquila. Nossa maior dificuldade é a falta de funcionários, falta de estrutura que gera uma discordância na equipe, falta de uma UTI, porque aqui é uma maternidade que a gente atende a região de Osasco, que é muito grande; pega casos muito graves e não temos 
Resultados

uma UTI, isso diminui muito a chance dessa paciente sair bem, diminui a chance de darmos uma assistência adequada para ela. A grande maioria das pacientes aqui não faz pré-natal e se são pacientes de risco os bebês não nascem bem. Nós temos uma UTI neonatal abarrotada, lotada. Precisamos aumentar a UTI neonatal e termos pelo menos dois a três leitos de UTI adulto. Acho que no centro de parto deveríamos ter mais cariotoco, exame de laboratório, por ser uma maternidade de risco, se você precisar de um hemograma com urgência não tem e mesmo para o pessoal da neonatologia eles querem os exames e não tem. Outra coisa ruim é a disposição da estrutura, como o banheiro: quando estamos atendendo uma paciente, o acompanhante de outra paciente quer ir ao banheiro e tem que passar no meio; isso fica estranho, todo mundo se vê. Acho isso muito inadequado, não sei como melhorar, mas essa estrutura fisica precisa mudar. O centro humanizado é muito legal, eu não sei porque não funciona, eu não sabia nem que aquilo existia, fiquei sabendo por que onde nós fazíamos medicação, por causa das chuvas, caiu e abriram aquela parte para fazer medicação temporariamente; ai que vimos que tem banheira. E isso seria muito bom, mas precisaria de uma equipe que tem vontade, porque não adianta você partejar, você insistir, você tem que estar com vontade, você não pode abandonar a paciente, tem realmente que gostar do que faz. Minha experiência aqui tem sido muito legal, é aquele negócio de amor e ódio, mas tenho muito prazer em vir para cá”. 
MO 3: "Aprendi tudo no São Luiz, que é um Hospital de primeiro mundo. Nunca tinha trabalhado com Saúde Pública, esta é a primeira vez. É muito diferente o atendimento, inclusive equipamentos e serviços. Aqui é a única maternidade de Osasco. E é referência de alto risco. É uma sobrecarga muito grande de pacientes. Atendemos muitas patologias. É um campo bom para aprender, estudar de novo. Esta maternidade é razoável. Tem deficiência de equipamentos, de médicos, de funcionários, como toda a maternidade pública. Ela é referência para muitas cidades, sendo que não estamos conseguindo nem comportar Osasco. Não aceitamos muitos pacientes externos, se não os pacientes do município não têm vaga. Fazemos o atendimento do paciente, discutimos as patologias, indicamos cesárea ou parto normal. E nossa intervenção mais direta é em cesárea, curetagens. Parto normal é feito pelas obstetrizes, sendo que quando são prematuros são acompanhados também pelo médico. A nossa função é fazer tudo isso e mais. É dificil porque o trabalho é pesado e não tem muito plantonista. Devia ter cinco plantonistas, mas tem três trabalhando hoje. Na segunda já foi autorizado ter cinco, porque é mais pesado que os outros dias. Mesmo assim estamos em três, sempre trabalhando em déficit. A humanização passa por um conjunto de coisas, como um atendimento bom dos funcionários. Para isso, precisa haver um treinamento dos funcionários, inclusive da equipe médica, para melhorar essa humanização. Tenho notado que, por exemplo, as pacientes estão indo ao pré-natal com mais consultas por causa do SIS Pré-natal, que é um programa que você cumpre uma série de metas, ultrasson, sete consultas, todos os exames pedidos e você ganha um "plus" financeiro em cada paciente que é feito completo. O hospital que atende também ganha outro "plus". Isso é bom, pois aumenta o dinheiro para o hospital. O espaço físico aqui não é tão complexo, mas tem bastante espaço. Agora, tem outros setores que têm banheiro, têm obstetriz e aparelhos para elas. As obstetrizes se viram muito bem com os aparelhos disponiveis. Existe certa deficiência, pois não temos aparelhagem mais moderna quanto às mesas, o foco de luz, o material cirúrgico. Isso é um reflexo da política brasileira, cujo presidente vê o que quer ver. Nunca ninguém olha para a saúde. A saúde é o ponto de início da campanha, mas depois de eleito ninguém faz nada por ela. Estou há um ano no Amador Aguiar, mas sou diretor de saúde em Carapicuíba, diretor clínico de saúde da Secretaria e vejo saúde pública no Brasil há 18 anos. A implantação do CPN aqui é efetiva, tem obstetriz, que em muitos lugares não tem; este hospital é Amigo da Criança. Tudo funciona com programas que, para estar dentro deles, tem que cumprir as metas que pedem. Uma boa assistência começa num pré-natal bem feito, diagnóstico preciso, seguir todos os passos do prénatal, observação da saúde da paciente da parte clínica e no hospital o que conta é o atendimento. Aqui acho que o atendimento não é ruim. A equipe é bem formada, atende em outros lugares, todos fazem residência. Os profissionais atuam bem, em especial as obstetrizes. O que tem deficiência é em número de funcionários em todas as áreas. Fico satisfeito quando tem pouca gente, quando tem muita gente, não. Mas tem certa satisfação. Trabalhar aqui, principalmente no plantão de segundafeira, é muito dificil, tem muita consulta, muito trabalho, então desgasta o nosso humor. Para melhorar precisava fazer outro Amador Aguiar. Se desse para fazer dois, era melhor. É o que precisa para melhorar o serviço, porque você vê a UTI neonatal que tem 24 vagas e geralmente está com 32 crianças. Não temos condições de atender tão bem, porque vem muita gente aqui. Isso desgasta 
inclusive o médico que fica mal humorado por causa disso. Você acaba de atender quinze e vem mais oito ou nove fichas. Cansa o médico, que diz: não adianta eu fazer nada aqui porque quanto mais eu fizer mais vem. É desgastante, você não consegue ver o fim. Minha experiência de trabalho aqui é normal. Já trabalho com isso há 27 anos. Por um lado, é bom porque você vê mais patologias. Aprende a tratar melhor e ter mais segurança no tratamento. Além do prazer que tenho na atenção obstétrica. Obstetra é um cara meio doente, ele gosta do que ele faz”. 
MO 4: “A princípio eu não tinha muita vontade de ir para obstetrícia, mas como eu gosto das coisas mais dinâmicas, achei que a obstetrícia me ajudava nisso. Gosto de conversar com as mulheres, é um público que me interessa. Um amigo meu estava fazendo a residência aqui, me convidou e acabei vindo trabalhar aqui. Quando a mãe chega nós fazemos os exames para ver a vitalidade fetal; as que ficam internada vão para o CPN e lá elas são cuidadas pelas obstetrizes, que só nos chamam em caso de necessidade. Nosso contato maior com as pacientes que têm o parto normal é só nesse momento da internação, no primeiro atendimento e quando as obstetrizes nos chamam. Fora isso, fazemos as cesáreas, não fazemos visitas. Nós não temos um protocolo específico para todos os tipos de atendimento, geralmente seguimos aquilo que aprendemos na residência. Há alguns critérios para fazer a internação, alguns critérios na área burocrática, agora critério, protocolo mesmo de tratamento, não tem: seguimos mais o que trouxemos da formação. O que eu acho interessante nessa questão de humanização é o fato de você ter um acompanhante durante todo o trabalho de parto, as obstetrizes ficarem o tempo todo conversando com a paciente. No geral, o serviço aqui é muito bom. Quanto aos recursos existentes, eu não tenho muito contato para saber se estão sendo utilizados.Para mim, uma boa assistência é aquela em que o final seja feliz, quando a mãe entra e tudo ocorre como ela esperava. Nossa equipe tem um relacionamento excelente com a equipe de enfermagem, nos vamos lá elas vêem aqui; entre os médicos o entrosamento é muito bom. Tem algumas coisas de estruturas fisicas que precisam melhorar, precisamos de mais profissionais, porque a demanda é muito alta e é a única maternidade pública para essa cidade, que é muito grande, fora os arredores, que vêem também, acabando por faltar espaço e profissionais. Precisamos de mais salas para o centro cirúrgico, um espaço maior de CPN, para que uma paciente não fique tão próxima da outra. Estou aqui há dois anos e tenho aprendido muito. Minha experiência tem sido muito produtiva, gosto do hospital, gosto da equipe de enfermagem”. 
MO 5: "Estou no Amador a pouco tempo, cheguei aqui por indicação de amigos. Terminei agora a residência e vim pra cá por ser um hospital parecido com o da minha residência. É um hospital público, de grande porte, que tem patologia obstétrica, tem uma UTI neonatal. Aqui atendemos tanto a parte ginecológica quanto a obstétrica. Sempre vamos priorizar mais a obstetrícia, tanto no Centro Obstétrico quanto no alto risco. Atendemos um pouco de tudo, desde pacientes que veem por queixas mais simples, como dor ou infecções, quanto por pacientes que veem para ganhar por trabalho de parto ou intercorrências que têm durante a gravidez, como pressão alta, problemas no ultrasson. Além de algumas que veem porque não conseguem alguns exames ou não conseguem fazer um prénatal no posto e ficam preocupadas e vem receber algum tipo de atendimento. Somos nós que indicamos a internação no Centro de Parto Normal. Normalmente, as mulheres são assistidas pelas enfermeiras obstetrizes, mas estamos sempre supervisionando, dando suporte, principalmente quando elas chamam. Mas, quando chegamos no plantão pela manhã, olhamos a paciente, conversamos com as enfermeiras, damos conduta juntos. A grande maioria das vezes são as enfermeiras que observam e chamam caso haja algum problema. A conduta é dada tanto pela enfermagem quanto por nós. A humanização aqui tem uma certa deficiência, como em outros lugares. Parto humanizado não é uma parto que necessariamente é um parto natural sem ter analgesia. Se formos analisar, a maioria dos lugares não tem analgesia no trabalho de parto. No geral, o trabalho de parto aqui é conduzido naturalmente, mas não quer dizer que é o desejo da paciente. Vi uma única vez essa semana que foi feito analgesia e deu certo. Não é algo rotineiro, como em vários lugares. Quando conseguimos dar um bom suporte, tanto para a mãe quanto para o bebê, é uma boa assistência. Infelizmente, com aquilo que temos em mãos. Então, se você tem a possibilidade de fazer a analgesia, tem toda aparelhagem, todo o conforto que pode dar a ela, é uma boa assistência. Tudo aquilo que a gente pode; porque nem sempre podemos fazer o que é o melhor. Principalmente em hospital público você não consegue dar tudo o que é possível. Porque não temos o material necessário e mesmo o material humano necessário. Então, esta paciente e seu bebê têm que ser avaliados constantemente. Então, se fazemos tudo o que podemos pela paciente, acho que é uma boa assistência. Tudo o que estiver ao nosso alcance, negligência, jamais. Por incrível que pareça, hospital público, em relação ao parto normal, é muito mais equipado do que o particular. Temos aqui muitos recursos disponíveis, por exemplo, cardiotoco disponível, amniotomo, diferente de hospitais particulares que trabalhei, que não têm. Apesar de todos acharem que os recursos são limitados, não são. O básico para você conduzir o trabalho de parto, conseguimos ter. O que muitos falam que devia ter é analgesia. É dificil para qualquer lugar, sem contar que não é todo o anestesista que tem habilidade de fazer. Além de faltar funcionários, porque a partir do momento que você faz uma analgesia, tem que ficar junto. Isso é o que falta, precisa algo novo e a tendência é evoluir. Nosso centro de parto é grande. As meninas são bem preparadas. Este hospital é bem gostoso de trabalhar, porque tem tudo o que precisa. Mas é um hospital que você vem preparado para trabalhar muito, porque a todo momento tem um fluxo muito grande. Principalmente, na segunda-feira. Tem bastante movimento na porta, mas é gostoso, o ambiente é muito bom de trabalhar. Apesar do fluxo grande, o entrosamento é perfeito, em relação a isso, a equipe é bem unida”. 
MO 6: "Já na faculdade, me identifiquei com a obstetrícia. Quando entrei no Amador, tudo já estava como agora, então não vivenciei nenhuma mudança aqui. Nossa relação com o pessoal do centro de parto normal sempre foi muito boa, até mesmo porque sempre era a mesma equipe, pessoas com a qual já estávamos habituadas a viver, sabendo qual é o ritmo de trabalho, saber se confia naquela pessoa e agora com essa mudança de escala, estamos trabalhando com pessoas que não trabalhávamos antes e isso causa uma insegurança, tanto para o pessoal que trabalha no CPN quanto para a gente, no fato de não conhecermos as práticas daquela pessoa e não podendo afirmar que confia naquela pessoa e isso só se desenvolve com o contato mesmo. Com a equipe que trabalhávamos até então tínhamos a segurança de poder conversar, discutir um caso ou coisa assim. Isso mudou e estamos sentindo a diferença, mas creio que é questão de convivermos com essas pessoas que estão agora e vamos ter o mesmo entrosamento de antes. Nunca houve de alguém do CPN interferir na conduta médica de forma muito grave; já houve casos de discutirmos por divergências de pensamento, mas, no fim, chegamos a um consenso. Fora isso, nunca tivemos nenhum atrito ou problema. Aqui trabalhamos juntos, atendemos as pacientes, de acordo com as queixas direcionamos os tratamentos, quando tem alguma indicação de procedimento, dividimos qual parte da equipe que vai atendê-lo, se por ventura a paciente tiver necessidade de internação, nós preenchemos a papelada dela enquanto o pessoal de enfermagem vai vestindo ela com a roupa de internação, juntando as coisas dela, para que sejam entregues ao familiar. Se ela estiver em trabalho de parto, fazemos a amnioscopia, para saber se essa paciente pode evoluir nesse trabalho ou não; no caso de estar tudo ocorrendo bem, ela é encaminhada para o CPN, onde faz o cardiotoco que vai dizer se esse feto está bem, se poderemos investir nesse parto normal. Ao longo do tempo em que ela estiver lá, vamos acompanhando essa evolução do trabalho de parto, porque se a qualquer momento houver uma alteração essa paciente vai ser submetida à cesárea.No momento em que essa paciente chega nós já identificamos o que é um mecônio, um DPP, e direcionamos na mesma hora para o centro cirúrgico e fazemos cesárea de urgência. Realmente, cada conduta vai ser de acordo com o quadro da paciente. Considero uma boa assistência quando a paciente é informada do que está acontecendo com ela, porque acontece de, às vezes, a paciente ser internada sem ao menos saber o que está acontecendo, Dizer a ela o que vai ser feito, quais as possibilidades. Tem paciente que pergunta: 'Ah, mas não pode ser cesárea?', respondemos que, a principio, ela tem tudo para evoluir para um parto normal, porém, se no decorrer do trabalho de parto houver alguma irregularidade, você pode ficar tranquila que será submetida a uma cesárea. Então a paciente já vai para dentro sabendo tudo. Uma boa assistência é submeter a paciente ao que ela precisa que seja feito e seja informada a respeito disso, isso por parte dos médicos, pois a enfermagem vai cercá-la com todo cuidado que é rotineiro, que são de protocolo, que todas as pacientes são submetidas as mesmas condutas. Necessitamos de maior estrutura física aqui, mais salas de atendimento, mais profissionais, tanto médicos quanto enfermeiros, quanto auxiliares. Tanto é que acontece de um funcionário faltar e vira um caos, porque a gente acaba fazendo o que é o pessoal da enfermagem que faria, porque não tem jeito, precisa ser feito. Se pudéssemos ter um serviço de ultrassom 24 h seria ideal, porque é a única maternidade pública de Osasco, o volume dessa maternidade é absurdo e fora as pacientes de 
Resultados

outras regiões que preferem vir aqui e acabamos tendo que passar por situações de ter que transferir pacientes, porque não tem vaga, pois a neonatologia está lotada; acabamos por ter que negar vagas de pedido de transferência de outras pacientes da região, porque não tem vaga nem para as pacientes que estão aqui. Para a demanda da maternidade, o porte deveria ser maior.Aqui, se tivesse oito plantonistas, não estaria sobrando ninguém, teria trabalho para todos. Minha experiência nesse hospital tem sido muito positiva, adquiri muita experiência trabalhando aqui, porque é um lugar onde tudo acontece e, quando acontece alguma coisa, posso dizer: 'vamos fazer assim, porque já vi esse caso e é assim que acontece'. E então, nesse sentido minha experiência aqui sempre foi muito positiva, graças a Deus não tive nenhum problema aqui”. 


\section{OS ESQUEMAS CONCEITUAIS, OS DESCRITORES CULTURAIS E O SUBTEMA CULTURAL}

DC1 - O temor relativo ao CPN superado pela constatação de sua efetividade

- O temor de implementar o CPN e as precauções adotadas

- Desconfiança na capacidade das parturientes se adaptarem ao novo modelo de assistência ao parto

- Inexperiência em atuar conjuntamente com enfermeiras obstetras na assistência ao parto

- Ter responsabilidade pela assistência ao parto

- Garantir resultados obstétricos favoráveis

- Supervisão do trabalho da enfermeira obstetra

- Averiguação das possibilidades para o parto normal

- Constatação da efetividade do CPN

- Confiança na atuação da enfermeira obstetra e valorização de seu papel

-Valorização do acompanhante e de seu papel

- Constatação da efetividade do serviço 
Os médicos obstetras demonstravam grande temor em relação à implementação do CPN, pois isto significava a incorporação de um novo modelo de assistência ao parto em relação ao qual não tinham experiência anterior. Isto fez com que eles tenham adotado inúmeras precauções.

O temor em relação ao novo modelo de assistência ao parto emergia da desconfiança em relação à capacidade das parturientes se adaptarem ao novo modelo assistencial que seria desenvolvido em um CPN. Os médicos obstetras temiam que as mulheres pudessem dificultar o desenvolvimento da assistência ao parto. Este temor era causado, sobretudo, pelo fato delas serem provenientes de famílias carentes e, consequentemente, enfrentarem dificuldades de adaptação ao modelo assistencial proposto no CPN. Com as experiências tidas com essas parturientes, esses profissionais puderam constatar que as dificuldades que eles tinham imaginado existir puderam ser superadas por meio de orientações e diálogos mantidos com elas.

\footnotetext{
"Fui até bem resistente em relação a isso, pois indaguei como conduziríamos? Seria possível com uma população carente? Essa população estaria preparada para estar dentro de um Centro de Parto? Será que ela ia facilitar a tua vida ou dificultá-la? Mas depois percebi que era uma questão de diálogo, de explicar, orientar". (1)
}

Outro fator que originou a resistência dos médicos obstetras foi a inexperiência de atuação conjunta com enfermeiras obstétricas na prestação de assistência ao trabalho de parto e parto. Desde a fase de formação acadêmica, os médicos obstetras não tinham presenciado ou tido experiências de atuação em conjunto com as enfermeiras obstetras.

"Essa questão da enfermeira obstetra dentro do Centro de Parto, para o médico, é nova, porque nenhum médico tem formação ou adaptação para este tipo de trabalho na residência. Ninguém se forma com enfermeiro obstetra em nenhum lugar...", (1)

Observou-se que os médicos obstetras tomavam para si a responsabilidade pela assistência obstétrica e adotavam medidas para garantir resultados positivos para o parto. Desse modo, faziam, mesmo que de forma discreta, a supervisão do trabalho desenvolvido pela enfermeira obstetra, pois avaliavam que 
cabia a eles responder por possíveis resultados desfavoráveis que poderiam surgir. Portanto, permaneciam atentos às possíveis intercorrências que surgissem no decorrer da evolução do parto.

“... quando elas sentem que algo está errado, quando o partograma começa a apresentar algum sinal de distócia, elas nos chamam para observar isso. Dentro do possível, vamos supervisionando mesmo sem elas chamarem, porque tudo o que acontece lá dentro é de responsabilidade médica. Temos que estar atentos, pois vamos responder ou resolver alguma intercorrência que aconteça”. (1, 2, 3, 4, 5)

Referiam estar cientes da responsabilidade em relação aos resultados obstétricos, portanto, diziam que ao realizar a internação das parturientes, averiguavam as possibilidades efetivas que estas mulheres tinham para progredir para o parto normal. Adotavam estas medidas com o intuito de garantir resultados obstétricos e neonatais positivos.

“Quanto aos critérios de internação, nós usamos o critério absoluto de cesárea, no caso de já ter tido duas cesáreas ou mais, examinamos o líquido da paciente, o tamanho da barriga, examinamos se está indo tudo bem, se não está com contração uterina forte, depois vamos examinar junto o cardiotoco e ver se realmente tem tudo para ser um parto normal, se estiver tranquilo vai para o CPN. Se ficarmos inseguros em algum momento, investigamos mais para ver se vai ser uma cesárea”. $(2,6)$

Superadas as impressões iniciais que tinham levado os médicos obstetras a resistirem à ideia da implementação do serviço, com base nas experiências vivenciadas, eles passaram a visualizar a efetividade da assistência prestada no CPN e a valorizar a presença e a capacidade profissional da enfermeira obstetra.

"A implantação do CPN aqui é efetiva. Aqui tem obstetriz, que em muitos lugares não tem, e este Hospital é Amigo da criança. (...) Nosso Centro de Parto é grande. As enfermeiras são bem preparadas". $(1,3)$

Valorizaram também a presença do acompanhante de escolha da parturiente, pois puderam constatar que estes contribuem na assistência no trabalho de parto e parto. Estes fatos levaram os médicos obstetras a avaliarem a assistência desenvolvida no CPN de forma positiva. 
"O que eu acho mais interessante nessa questão da humanização é o fato de você ter um acompanhante durante todo o trabalho de parto, as obstetrizes ficarem o tempo todo conversando com a paciente. No geral, o serviço aqui é muito bom" $(1,2,3)$ 
DC2 - Muitos obstáculos dificultam a assistência ao parto adequada

- A assistência ao parto considerada adequada

Seguimento do protocolo do Ministério da Saúde

Seguimento dos preceitos da assistência obstétrica

Adequação da assistência pré-natal

Existência de equipe multiprofissional

Envolvimento do profissional com o trabalho

- Obstáculos que dificultam a assistência adequada

Inadequação das políticas públicas e suas consequências

- Falta de participação do acompanhante

- Falta de orientação das gestantes

- Fluxo elevado de atendimentos

- Recursos humanos insuficientes

- Recursos fisicos e materiais insuficientes elou inadequados

Ausência de protocolo assistencial 
Os médicos obstetras fizeram referências ao que consideravam como uma assistência adequada ao parto e aos muitos obstáculos que enfrentavam para colocá-la em prática.

Quanto à adequação da assistência, consideraram a necessidade de seguir o que estava determinado pelo Ministério da Saúde em relação à assistência ao parto. $\mathrm{Na}$ avaliação destes médicos, isto requeria necessariamente o envolvimento multidisciplinar.

\footnotetext{
"Uma boa assistência, para mim, é seguir o que é preconizado pelo Ministério da Saúde e pelos preceitos obstétricos que conhecemos. Isto requer um trabalho multidisciplinar". $(1,3)$
}

A existência de uma assistência pré-natal adequada também foi avaliada como fundamental para o êxito da assistência ao parto. Segundo a visão destes médicos obstetras, a mulher fica mais segura ao ser informada antecipadamente sobre o processo do nascimento e o atendimento prestado na maternidade. Alem disso, foi avaliada a necessidade da estruturação da equipe assistencial, para que não venham a surgir atritos no decorrer da assistência ao parto.

“...uma boa assistência é sentir firmeza na equipe inteira, ver uma equipe bem estruturada para não ter atrito entre a equipe $e$, quando for para o CPN, ser assistida, encontrar tudo que é necessário e importante para aquele momento”. (2, 4, 6)

O envolvimento do profissional com a assistência ao parto, o que na visão destes profissionais requer o gosto pela profissão e pelo trabalho desenvolvido, foi um aspecto considerado fundamental para a qualidade da assistência.

“...mas precisaria de uma equipe que tenha vontade, porque não adianta você partejar, você insistir, você tem que estar com vontade, você não pode abandonar a paciente, tem realmente que gostar do que faz". (2)

Os profissionais afirmaram que eles se deparavam com muitos obstáculos que dificultavam a implementação da assistência que consideravam ser adequada. 
Foi referida a política pública vigente, que não prioriza a assistência a saúde e que, deste problema, derivam muitos outros que atingem a esfera da assistência obstétrica no país. Referiram que não encontram condições humanas e materiais para prestar a assistência que gostariam para as parturientes atendidas na instituição. Consequentemente, referiram ser obrigados a fazer o possível com o que dispunham e, infelizmente, nem sempre podiam fazer o melhor para as mulheres.

\footnotetext{
"Nem sempre podemos fazer o que é melhor para a mulher, mas fazemos o que está ao nosso alcance, porque não temos o material necessário e mesmo o material humano para trabalhar". (1, 2, 3)
}

A ausência de orientação adequada às mulheres também foi considerada ruim, pois chegavam inseguras, quanto ao momento do parto, e temerosas, quanto às dores, pela falta de amparo psicológico e da instrução devida. Referiram que as mulheres necessitam de informação para tomarem as melhores decisões para si, porque, se conhecessem os perigos inerentes as cesarianas, certamente optariam pelo parto normal. Reconheceram que existia carência de orientação, pois não conseguiam fornecer explicações suficientes a respeito da evolução do parto, devido ao grande volume de parturientes a serem atendidas.

“...se ela chegasse aqui sabendo tudo o que irá acontecer ela não diria que quer uma cesárea, pois se ela soubesse o risco que é uma cesárea elas iriam brigar com a gente por um parto normal e é isso que falta explicar para ela desde o começo: como as coisas vão acontecer, se virar cesárea por que acontecerá" $(1,2,6)$

Avaliaram também que a ausência do acompanhante de escolha da mulher nas consultas pré-natais prejudicava o desempenho do seu papel, que consideravam ser de grande importância no processo do nascimento.

“A principal mudança não deveria ser aqui, mas sim no pré-natal, o acompanhante deveria estar presente também. $O$ marido ou a sogra precisam participar e ouvir as orientações, porque teoricamente este médico orienta sobre o trabalho de parto e se chegassem sabendo o que vai acontecer seria mais fácil. Não acontece esse tipo de orientação nem para a paciente, quanto mais para o acompanhante". $(1,2)$ 
Um grande problema referido foi o fluxo elevado de atendimentos. Referiram a existência de uma alta demanda de parturientes originárias de municípios vizinhos e do próprio município de Osasco, onde a instituição está situada. Relataram a existência de sobrecarga de trabalho, que causava grande insatisfação e desgaste.

"É uma sobrecarga muito grande de pacientes, atendemos
muitas patologias. Esta maternidade é razoável, tem deficiência de
equipamentos, de médicos, de funcionários como toda a
maternidade pública. Ela é referência para muitas cidades, sendo
que não estamos conseguindo comportar nem Osasco". $(3,4)$

Foram feitas referências ao grande déficit de recursos humanos e materiais para o atendimento no $\mathrm{CPN}$.

Referiram que, a princípio, havia a previsão da atuação de uma equipe de fisioterapeutas no CPN. Recordaram que nos primeiros anos após a abertura do CPN, estes profissionais sempre estavam presentes para prestar assistência. Avaliaram que a presença destes profissionais era importante, pois forneciam orientações relativas à evolução do parto, colaboravam, fornecendo suporte emocional às parturientes, promoviam o conforto e $\mathrm{o}$ acolhimento para as parturientes. Referiram que, ultimamente, estes profissionais atuavam apenas de forma esporádica no $\mathrm{CPN}$.

"As fisioterapeutas ajudavam bastante, orientavam, aconselhavam a questão mecânica do parto, colaboravam com o aspecto psicológico, porque estavam próximas. Isso dava conforto e acolhimento". (1)

Foram também feitas referências ao número reduzido de profissionais em cada plantão. Exemplificaram que em um plantão em que deveria haver cinco médicos obstetras, em geral estavam presentes apenas três. Referiram que este era um fato recorrente e que constantemente tinham o quadro reduzido de médicos no plantão. Relataram que, mesmo que houvesse oito médicos presentes em cada plantão, ainda assim todos teriam muito trabalho a realizar. 
A estrutura física também foi considerada insuficiente e inadequada pelos profissionais, tendo em vista a grande demanda de parturientes que vinham em busca de assistência ao parto neste serviço. Avaliaram que o espaço disponível para cada leito era insuficiente e, consequentemente, as gestantes tinham que permanecer muito próximas uma das outras. Consideraram que a disposição do banheiro causava constrangimento a algumas mulheres, pois ele estava localizado ao final do corredor. Assim, para que o acompanhante de outra parturiente usasse este banheiro, ele era obrigado a passar entre os leitos, fazendo com que as mulheres fossem expostas a estranhos.

"Tem algumas estruturas fisicas que precisam melhorar, (...) precisamos de mais salas, um espaço maior para o $C P N$, para que uma paciente não fique tão próxima da outra”. (5, 6)

Os médicos recordaram que havia a previsão da utilização de muitos outros recursos de assistência ao parto na época da inauguração deste CPN. Dentre estes recursos, destacaram a banheira que está localizada no Centro Humanizado. Entretanto, referiram que a utilização desta banheira, assim como do cavalinho, nunca foi efetiva. Acreditavam que a não utilização da banheira, desde a época da inauguração do serviço, estava relacionada com a dificuldade de manter a assepsia adequada, devido à alta demanda de parturientes a serem atendidas.

"O projeto inicial do CPN previa o uso da banheira, mas na prática não fazemos uso desses recursos, não tem banheira, nada”. (1)

Lamentaram a precariedade dos recursos disponíveis para prática assistencial. Fizeram referências aos aparelhos disponíveis, que eram antigos e em quantidade limitada, entre eles o número reduzido de sonares obstétricos em uso. Queixaram-se também da ausência do serviço de ultrassonografia durante as 24 horas do dia. Isto representava, para os profissionais, um grande fator dificultador da assistência. Relataram que, em algumas ocasiões, tiveram a necessidade de abrir a sala de ultrassom para fazer a avaliação das parturientes, mesmo sem serem especialistas neste tipo de recurso diagnóstico. Acreditavam que esta precariedade também era fruto das políticas públicas de saúde, consideradas por estes profissionais como extremamente deficitárias. 
"Existe certa deficiência, pois não temos aparelhagem mais moderna quanto às mesas, o foco de luz, o material cirúrgico. Isto é um reflexo da política brasileira”. $(1,3)$

Referiram também a ausência de protocolos de atendimento claramente delimitados. Este problema ocasionava a ocorrência de muitas diferenças entre os critérios de internação e nas demais práticas, que eram divergentes entre os médicos obstetras. Este fato foi confirmado durante o processo de OP.

“... nós não temos um protocolo específico para todos os
tipos de atendimento, geralmente seguimos aquilo que
aprendemos na residência, há alguns critérios para fazer a
internação, alguns critérios na área burocrática, agora protocolo
mesmo de tratamento não tem: seguimos mais o que trouxemos na
formação." (5)

STC 3 - Um árduo cotidiano assistencial que impede o desenvolvimento da assistência desejada 


\subsection{OS MÉDICOS NEONATOLOGISTAS, SUAS CARACTERÍSTICAS, SUAS NARRATIVAS, O ESQUEMA CONCEITUAL E O SUBTEMA CULTURAL}

A equipe de médicos neonatologistas está disposta conforme o quadro 4 abaixo:

Quadro 4 - $\quad$ Os médicos neonatologistas e suas características. São Paulo, 2011

\begin{tabular}{|c|c|c|c|c|c|c|c|c|c|}
\hline Entrevista & Idade & Naturalidade & Religião & Estado Civil & Paridade & $\begin{array}{l}\text { Maior Grau } \\
\text { Escolaridade }\end{array}$ & $\begin{array}{c}\text { Tempo de } \\
\text { experiência } \\
\text { profissional } \\
\text { na área }\end{array}$ & $\begin{array}{l}\text { Tempo na } \\
\text { Instituição }\end{array}$ & $\begin{array}{c}\text { N de } \\
\text { Empregos }\end{array}$ \\
\hline \multicolumn{10}{|c|}{ INFORMANTES-CHAVE } \\
\hline MN 1 & 36 & São Paulo & - & Casado & 1 & Especialização & 1999 & 6 anos & 2 \\
\hline MN 2 & 43 & São Paulo & Católica & Casado & 1 & Especialização & 1995 & 11 anos & 2 \\
\hline \multicolumn{10}{|c|}{ INFORMANTES GERAIS } \\
\hline MN 3 & 46 & $\begin{array}{l}\text { Rio Grande do } \\
\text { Sul }\end{array}$ & Católica & União estável & 1 & Especialização & 1991 & 8 anos & 2 \\
\hline MN 4 & 51 & São Paulo & Evangélica & Casada & 3 & Especialização & 1983 & 6 anos & 3 \\
\hline MN 5 & 44 & São Paulo & Judaica & Casada & 2 & Especialização & 1990 & 4 anos & 2 \\
\hline MN 6 & 31 & São Paulo & - & Solteiro & - & Especialização & 2005 & 1 ano & 3 \\
\hline
\end{tabular}

Nesta pesquisa, observa-se que os 6 médicos neonatologistas que colaboraram tinham entre 31 e 51 anos, com média de 41 anos; cinco deles eram naturais de São Paulo e um do Rio Grande do Sul. A média de paridade era de dois filhos. Quatro eram casados, um referiu ter união estável e era solteiro. Todos possuíam especialização em neonatologia.

Quanto à religião, dois declararam ser católicos, uma era evangélica, uma tinha a religião judaica e dois não referiram ter religião. Quanto ao ano de término da graduação, o período foi de 1983 a 2005. Quanto ao tempo na instituição, variou de 1 a 11 anos, com média de 10 anos. A média de empregos dos médicos neonatologistas foi de 2 empregos. 


\section{As suas narrativas}

MN 1: "Estou na Maternidade desde 2003. Na época, o serviço era feito por menos neonatologistas e médicos pediatras. Não tenho certeza, mas talvez por menos obstetrizes. Aparentemente, o atendimento era numericamente maior. Não tinha o mesmo tempo de focar o atendimento humanizado. Era uma linha de montagem, que a paciente sabia que seria tratada daquela forma e muitas vezes nem reclamava. Os plantões eram maiores. Eram plantões de 24 horas semanais seguidos. Era difícil ficar um periodo livre ou dividir horário com colegas ou fazer plantões de doze horas ou até tirar férias. A falta de profissional era maior do que é agora. Com relação a material, não vejo muito mudança porque os materiais que usamos na neonatologia, na recepção do recémnascido no Centro Obstétrico, é um material relativamente simples e o que tivemos de melhoria e inovação tecnológica temos aqui na UTI. No Centro de Parto a única coisa que tivemos observada melhora foi a parte estrutural, fisica mesmo: paredes, piso, ar condicionado, maca para mãe. Aqui tem uma variação muito grande de atendimentos e não é uma sazonalidade é uma eventualidade de atendimentos; de repente nascem dez em três horas e às vezes fica oito-nove horas sem nascer algum bebê. Tem muito disso aqui e em qualquer lugar onde se espera ter mais partos normais do que cesáreas. O que vemos é que hoje em dia tem menor volume de parto, mas a gravidade está um pouco maior, a permanência e o número de internações na UTI está maior. Tem dia que temos mais de 30 bebês internados em regime de UTI ou semi-UTI, sem ter espaço fisico e material, claro que sempre se resolve: aluga-se material e não chega a faltar nada para o bebê. Mas o estresse, o volume de trabalho aumenta do funcionário aumenta logo o risco de uma condução não adequada aumenta também. Da parte de neonatologia no CPN e no CO o que usamos é muito simples: um berço aquecido, um oxigênio, um vácuo, sonda de aspiração, cânula de entubação, laringoscópio, eventualmente uma sonda para cateterização umbilical e medicações de urgência, adrenalina, sorofisiológico. O material não mudou muito no atendimento nos últimos anos. Mudou o protocolo, o fluxograma, mas não mudou o material em si. Não teve uma mudança grande para, nós mas para a obstetrícia sim. Porque mudou o tipo de atendimento, uma visão melhor do Centro Cirúrgico para o Centro de Parto Normal, que foi a humanização. Os chuveiros, banheira, essa parte realmente mudou e você pode perceber o atendimento mais humano. A presença dos familiares junto realmente acalma as mulheres, mas na parte de gravidade e de excesso de volume de partos ou de pacientes que veem de outras regiões isso é algo que atrapalha no atendimento aqui de quem é de Osasco. Muita gente de outras cidades, a propaganda do Centro de Parto Normal lotou muito e isso é ruim para gente, para o cidadão do municipio. O neonatologista é contratado para cobrir toda neonatologia do hospital. Nós dividimos o serviço; quem faz o atendimento só do ambulatório e os médicos que fazem o seguimento de diarista para acompanhar os bebês internados ou quem faz um periodo maior de horas na semana, que é o meu caso. Venho na segunda, às 7 da manhã, quem passa o plantão da noite informa as intercorrências, os bebês que estão internados na UTI, o que colheu de exame, alguma dificuldade especial e você fica de sobreaviso, porque qualquer bebê que nasce tem que ter a presença do neonatologista, que vai até o local onde esse bebê está nascendo, seja no Centro Cirúrgico ou CPN, enquanto isso vamos evoluindo os bebês normais do Alojamento Conjunto ou, 
havendo intercorrências na UTI, observamos-as também. Sempre ou estaremos tomando a conduta de algum bebê, que já nasceu, ou se está presente na sala de parto para assessorar e acompanhar os primeiros momentos do bebê. Se nascer muito bebê no período em que você tem que examinar, isso embola um pouco o seu atendimento. Na segunda-feira temos uma equipe boa, coesa, que se comunica sempre, as obstetrizes estão presentes a todo momento, nós estamos sempre indo lá; conversamos. temos um bom relacionamento com os diaristas de hoje também. Realmente não é todo dia que isso acontece, tivemos a sorte de nos juntarmos na segunda-feira com colegas que se identificam e têm bom relacionamento, assim conseguimos manter um bom trabalho, sem estresse.O plantão geralmente não é um trabalho tranquilo; tem seu estresse, você tem que fazer várias coisas ao mesmo tempo, não tem como parar de nascer ou fechar a porta do hospital e falar: 'não entra mais ninguém'. Pessoas que passam mal na porta, que querem entrar, querem atendimento, acham que aqui também tem atendimento, isso gera um desconforto e o médico tem que atender, está no código de ética jurado por nós. A humanização que se faz aqui é a permanência voluntária do bebê com a mãe, a possibilidade do acompanhante ficar junto no momento do parto, três horários de visita, presença de um anestesista, caso precise de um procedimento mais doloroso, melhoria das acomodações, de banheiros novos, banheira, ar condicionado. Isto gerou melhoria no atendimento e conforto para os pacientes. Agora, a humanização excessiva, radical, como há em alguns locais, eu não concordo, porque pode atrapalhar um pouco. Tanto a evolução da criança quanto atuação do médico neonatologista. Se forçar até o último instante o parto normal, mesmo que o bebê tenha sinais de sofrimento ou em casos de mecônio, você faz o parto normal vaginal. Uma boa assistência ao bebê é você saber ponderar o momento em que ele está bem confortável com a mãe após o nascimento e o atendimento mais invasivo, se não ele vai sofrer algum tipo de lesão, por exemplo, o bebê nasce, chora é colocado no colo da mãe. Isso é parte da humanização, mesmo sem ter cortado o cordão umbilical. Se você vê que ele está ficando cianótico, com necessidade de oxigenioterapia, se está engasgado ou com sinal de crise convulsiva, a humanização mais adequada que tem é você saber o ponto para atender o bebê e ele não pode sofrer algum dano que possa ser irreversível. $O$ atendimento tem que ser feito de forma bem entrosada por parte médica e de enfermagem para você entender e receitar uma parte do outro neste momento crítico, tudo bem pode esperar ou fazer algo invasivo no atendimento. Me sinto satisfeito quando o paciente te agradece. O que mais me dá prazer é o agradecimento. Depois de mais de 7 anos trabalhando aqui vejo que o que faz o lugar é a pessoa que trabalha nele, não o lugar ou a população atendida. Quando você tem um grupo de funcionários que não estão satisfeitos, ou se eles têm uma imagem ruim do hospital, as coisas ficam ruins e aqui tinha uma imagem ruim, mas isso tem mudado bastante, mas você vê que quando o funcionário fica reclamando do serviço, quando ele não vê nada de bom, faz com que o serviço seja visto de forma ruim. Se você conseguir juntar uma equipe disposta a trabalhar junto, fazer as coisas corretas e não ficar vendo tantos problemas, mas buscando melhor, faz com que o trabalho seja prazeroso e o resultado também". 
MN2: "Estou aqui no Amador desde junho de 2000, há quase onze anos. Tiveram muitas coisas dificeis, mas com o tempo as coisas estão melhorando, o método canguru, a humanização. Antigamente era pior, o número de nascimentos era bem maior do que atualmente, mas estamos melhorando, a equipe esta querendo trabalhar e aos poucos estamos indo. Quanto a minha assistência, assim que a obstetra vê que está para nascer a criança, ela nos chama. Então, recepcionamos $R N$, se ele nascer bem, fazemos a limpeza, passamos a sonda orogástrica, para ver se está tudo bem, e a enfermeira dá todos os cuidados. Atualmente, fazemos parte do Hospital Amigo da Criança, então, assim que corta o cordão umbilical, coloca-se a criança no peito da mãe. Esse é o passo quatro do amigo da criança, o contato pele a pele. Quando cheguei aqui não tinha CPN, somente Centro Obstétrico. Primeiramente, mudaram a questão estrutural para fazer o Centro de Parto Humanizado, o parto cesárea era praticamente junto com o parto normal. Depois passou a ser separado. Criaram uma área para ficar as mães junto com o acompanhante, que antigamente não tinha, separávamos o bebê da mãe, agora não, o bebê nasceu já fica do lado da mãe, tanto é que o berço fica dentro da sala cirúrgica, a mãe acompanha todos os passos até ficar com ele e ir para o quarto. Isto foi uma mudança boa para a mãe e para o companheiro, que fica junto da hora que nasce até o momento que vai para casa, é importante estimular com que mãe, pai e bebê fiquem juntos o tempo todo, como também promover o amamentação na primeira hora de vida, pois isso cria um vínculo maior entre mãe-filho, que é nossa função principal, a de criar um vínculo melhor entre o bebê e a mãe. Na implantação do CPN teve uma certa resistência quanto a esses procedimentos da enfermagem, médicos, porque cada médico aprendeu de uma maneira diferente em uma cultura diferente, mas essas barreiras foram se retirando aos poucos, através de cursos, aulas, orientações, conforme as pessoas foram vendo que funciona. Ainda tem algumas resistências, como, por exemplo, o tempo; algumas vezes não querem ficar lá e deixar o bebê com a mãe. Às vezes nascem muitos bebês e não conseguimos dar toda atenção, por isso precisamos de mais funcionários, percebemos que não tem funcionários para dar o tratamento adequado, elas fazem com o maior esforço, mas algumas vezes não conseguem. Então, tem uma certa resistência com isso, dizer que parto humanizado é parto que nasce igual bicho, tem gente que fala 'nasce igual animal', porque não precisa fazer nada, é só deixar nascer, mas temos que mudar a cabeça das pessoas; aos pouquinhos; verem o que é bom, tanto para a mãe quanto para o bebê. Para fornecermos uma boa assistência temos que ter material adequado, funcionários treinados adequadamente, médicos, enfermeiras, faxineiras, todos entrosados na mesmo objetivo, todos falando a mesma linguagem, não pode um falar diferente do outro. E, para isso, tem que ter cursos, às vezes falta material, mas isso faz parte. Já tivemos épocas piores, quando não tínhamos nada. Está melhorando, temos um pouquinho de dificuldades, resistências, questões burocráticas para conseguir algumas coisas, mas, aos pouco, conseguimos o que precisamos. A melhor coisa que podemos dar é a atenção, qualquer tipo de atenção extra que damos para o paciente, já melhora 100\%. Ter educação, conversar, você vai ver que modifica”. 
MN 3: Comecei a fazer neonatologia em 2002. Na época minha esposa estava grávida, já era pediatra e fui para a USP fazer uma especialização. Em 2003 prestei o concurso público, fui aprovado e comecei a trabalhar aqui. Iniciei meu contato com a neonatologia porque antes ficava em pronto socorro. Foi meu primeiro emprego em neonatologia. Entrei em contato com todas as patologias, centro cirúrgico, centro obstétrico, sala de parto, os prematuros, as doenças infecciosas, o alojamento conjunto, o método 'mãe canguru' e toda rotina da neonatologia, a UTI neonatal, cuidados intermediários, cuidados especiais, isolamentos. Ficamos com três plantonistas, mais uma equipe de diaristas. Vemos as intercorrências da UTI e fazemos visitas no alojamento conjunto. Quando tem sala de parto, pegamos os bebês também. A maioria nasce bem, só de 10 a 20\% precisam de algum procedimento e 1 a $2 \%$ precisam de UTI ou algum tipo de cuidados intermediários. É bastante gratificante quando dá tudo bem. Quando dá errado você é o culpado, pois não conseguiu reanimar e o bebê vai para a UTI com algum tipo de sequela. O serviço está melhorando muito. Já estamos tirando bebê com menos de um quilo. Antes era sonho, agora é realidade. A mortalidade perinatal abaixou bastante. Estamos tentando ampliar a humanização. $O$ contato pele a pele, o aleitamento materno na primeira hora de vida junto com a mãe, para melhorar o alojamento conjunto e ter uma decida do leite melhor. Na humanização fazemos um exame rápido da mãe, preenchemos uma ficha e fazemos os primeiros passos, que são: colocar sobre o calor radiante, posiciona, seca as vias aéreas, faz os exames fisicos direto para posteriormente ver se tem alguma malformação grosseira. Se não tiver alguma contraindicação indico o aleitamento materno na primeira hora. Temos visto uma tendência do corte tardio do cordão, esperar pelo menos um minuto assim o bebê tem o aporte de sangue, não tem tanta anemia. Se estiver tudo bem pode colocar já no seio. Se tiver algum problema, fazer a reanimação. Tudo que é novo sempre tem uma barreira. Mas com a humanização melhorou o contato com os profissionais, com os pacientes. O pai na sala de parto, podendo ver o parto, podendo acompanhar cada momento. Nós temos uma equipe muito experiente de obstetrizes. Quando acontecem as complicações, elas nos auxiliam. Antigamente, tinha muita asfixia, muito bebê deprimido. Hoje são poucas complicações, porque não deixam acontecêlas e as que acontecem são aquelas curva de corte que vai acontecer mesmo nas maternidades. Por outro lado, aumentou a incidência de parto cesárea. Hoje, tem dia com 10 a 12 cesáreas, porque, para o obstetra, qualquer coisa alterada, é melhor intervir para evitar complicação. Com os recursos que temos dá para fazer o básico. Tem sempre que melhorar, como a medicina é o advento da UTI da tecnologia e da internet tem melhorado rapidamente. Em reanimação, monitorizarão, essa alta tecnologia, esses reanimadores neonatais, não temos. No atendimento de parto normal a demanda aqui é muito grande. Mas, no geral, está indo muito bem. Precisa ter um oxímetro de pulso para monitorar o bebê. Temos em outro lugar. Tem que ter um aparelho de reanimação neonatal, um 'blender'. No geral, as coisas básicas, nós temos. Para mim, uma boa assistência é o desfecho do caso. Quando o bebê nasce bem ou se houver alguma intercorrência fazer os procedimentos para entregar o bebê para a mãe no alojamento conjunto, no seio materno. A cada dia vou tentando melhorar, como pessoa e profissional. As dificuldades surgem e, às vezes, nos deprime por causa da sobrecarga de trabalho, a distância que moro. A maioria do pessoal aqui tem muita experiência". 
MN 4: "Tenho vinte e oito anos de formada. Fiz residência em pediatria e depois dois anos em neonatologia. Há muitos anos que trabalho com isso, de doze a quinze anos. Cada vez mais preconizamos a humanização dos hospitais, não só da obstetrícia. Como somos dessa área da neonatologia, então tentamos uma integração da família. Tem sempre um acompanhante, um familiar apoiando, além da humanização do profissional da saúde, para que essa mãe seja acolhida sem denegrir e nem diminuir a eficácia e a competência do serviço. Não é por que você está permitindo que a família participe que vai abrir mão de tomar os cuidados necessários. O bebê e a mãe têm que ser bem assistidos, com todos os recursos necessários naquele momento. Com a participação da família, tem um vínculo maior mãe-bebê e com a instituição. Se promove muito mais fácil o aleitamento materno. O principal é que você seja transparente com a família do que está sendo feito. Uma coisa que é boa para a mãe é se sentir bem acolhida antes do parto. O profissional tem que se identificar e explicar o que vai acontecer. Isso tanto o neonatologista, quanto o obstetra e a obstetriz. No nosso caso, nos identificamos e fazemos um elo para que essa mãe se sinta acolhida. Porque, às vezes, é um parto demorado, onde essa mãe faz mais força. É importante que tanto o familiar quanto a equipe estejam envolvidos. Se é um bebê que nasce bem forte, vigoroso, podemos pô-lo na barriga dessa mãe antes mesmo de cortar o cordão, para que ela sinta seu bebê e se tranquilize. A nível hormonal é muito importante, pois diminui sangramento, a dor. Depois, pode fazer os outros procedimentos físicos, rotineiros com esse bebê. No caso de um bebê que precisa de aspiração, nosso procedimento é mostrar para a mãe o berço do bebê na sala, ser examinado se precisa de via aérea, de oxigênio ou não. Em seguida, esse bebê já volta para a mãe para ela senti-lo. A mãe que saiu da sala do parto e está na maca, fica com o seu bebê mamando, porque a enfermagem nesse sentido é muito boa. Os bebês que nascem com alguma patologia não tem como fazer isso porque a prioridade é a sobrevivência. O espírito aqui é humanizado. Basicamente, o que a gente precisa em uma sala de parto é um aspirador eficiente, fonte de oxigênio, uma caixa de emergência, material para cateterismo umbilical e medicações necessárias na reanimação. Temos o calor radiante, o oxímetro também, a nível de sala de parto. Não nos falta nada. Numa urgência, as obstetrizes nos ajudam para que não seja estressante para a mãe. Um problema que temos é que os exames, muitas vezes, não chegam na hora que queremos. A nivel de rede, nem sempre o pré-natal é bem feito. É um problema básico. Às vezes não tem cultura de estrepto dessa mãe. O bebê pode nascer ótimo e daqui a algumas horas pode correr risco de uma infecção grave. Melhorou, mas ainda encontro mãe sem pré-natal, com uma ou duas consultas, ou sem exame, e os motivos são diversos. O principal para melhorar seria a integração da rede com a maternidade, no sentido de incentivar o pré-natal bem feito. Com a reciclagem do médico até da enfermeira obstetriz, incentivo geral para que a gestante não falte. Tivemos uma grande queda de mortalidade infantil. Essa maternidade de seis a sete anos mudou muito. Temos uma cultura de parto normal aqui. As pacientes, em sua maioria, sabem que o parto delas será normal. As cesáreas são feitas com indicações. Em um centro de parto normal a própria roupa que se usa é muito mais tranquila do que em um lugar que há cirurgia, onde a assepsia tem que ser muito mais rigorosa. Uma boa assistência é um pré-natal adequado, as indicações corretas, a nível de ciência: se deve ser parto normal ou cesárea, por exemplo. E quando chega na maternidade, 
saber quem são os profissionais que vão cuidar dela, os seus familiares ao lado para dar apoio, uma atenção humanizada para a família, um pediatra na sala do parto, um assistente para esse pediatra, além de colocar o bebê na primeira meia hora junto da mãe e, na alta, a orientação adequada. Aqui temos um ambulatório de mãe-bebê, que, em 48 horas, todos os bebês são convocados a voltar para checar a amamentação, o peso do bebê, se não apareceu uma icterícia em casa. Na hora da alta é orientado. Não está tudo ideal, mas estamos batalhando para isso". 
MN 5: "Quando comecei a fazer medicina desejava ser anestesista, mas na residência optei pela pediatria, pois me identifiquei mais. Depois, fiz mestrado em neonatologia. Todos os hospitais que trabalhei foram particulares. Aqui no CPN a maioria dos partos são feitos pelas enfermeiras obstetrizes. Quando estou no CPN tenho pouco contato com o obstetra, geralmente quem conduz e faz o partograma é a enfermeira obstetriz, a obstetra que está de plantão só atua quando tem alguma complicação ou quando a enfermeira obstetriz solicita. Geralmente somos chamados em todos os partos normais, antes do nascimento. A enfermagem daqui é bem experiente porque nasce muita criança, a maioria dos partos são bem conduzidos, principalmente porque são partos normais mesmo, não tem analgesia, flui muito bem. Meu relacionamento com as enfermeiras é ótimo. A assistência ao RN é toda direcionada pela humanização, ninguém pega o bebê sem seguir as normas da Sociedade Brasileira de Neonatologia, geralmente a enfermeira já coloca o bebê em contato com a mãe, depois leva para a neo, que faz os procedimentos de reanimação normais. Se o bebê estiver vigoroso, chorando, só enxugo, faço os primeiros exames e imediatamente libero para ficar com a mãe no alojamento conjunto. No CPN, o bebê começa a mamar. Os bebês que não estão bem, os cuidados são outros: a enfermeira o entrega diretamente para o neo, que procede com a reanimação e encaminha, ou para o AC ou para UTI. Estou aqui há 4 anos e acho que poderia ser mais confortável. A área fisica é excelente, mas é tudo velho, você quer lavar as mãos, mas a torneira não está funcionando, nos quartos não tem pia para a mãe, aqui tinha condições de ser uma excelente maternidade, mas não é porque a assistência é difícil para o bebê e muito desconfortável para a mãe. Além de melhorar o espaço fisico, deveriam fazer uma reorganização do corpo clínico, porque tem muito médico de plantão em UTI neo que não tem formação intensivista e nem de neonatologista. Acho que isso não deveria ocorrer jamais, porque para esse colega que fez outra especialidade falta o refinamento da especialidade que não tem, isto faz com que as condutas se percam. Acho que cada um deve ficar na sua especialidade, perde muito na humanização também porque a alta não é feita na hora certa, a conduta, muitas vezes, não está correta, perde demais, perde 90\%, o profissional que não está absolutamente habilitado sempre deixa falhar em alguma coisa. Precisaria mudar um pouco essa dinâmica da UTI e do AC, falta integração entre os médicos da Unidade de Terapia Intensiva, dos médicos que passam no alojamento conjunto, às vezes fica um exame para ver no AC e o médico que está na UTI não quer ver. Essas coisas não devem acontecer, mas que não acontecem somente aqui. Quando vim para o Amador Aguiar não gostei, pensei: 'Meu Deus, não volto aqui nunca mais', só que vamos nos acostumando, gostamos da equipe, da enfermagem, dos colegas e acaba ficando. Uma boa assistência é um pessoal habilitado, um espaço fissico correto, material e então a humanização vai muito bem. Minha experiência aqui no Amador foi boa, já passei muitas dificuldades, mas isso é normal da profissão, se eu fiquei aqui é porque gostei”. 
MN 6: "Estou no Amador há um ano, vim aqui por convite da doutora Silvia que é uma das coordenadoras da equipe de neonatologia. Minha função é como médico plantonista, nas segundasfeiras, atendendo os bebês na UTI neonatal, na ausência dos diaristas. Faço atendimento no Alojamento Conjunto e na sala de parto, tanto no Centro de Parto Normal quanto no Centro Cirúrgico, para os bebês que nascem de partos cesárea ou fórceps. Os recursos disponíveis no CPN não utilizo diretamente como neonatologista. Porque quando os bebês vão nascer e as mães são levadas para a sala de parto, a equipe me telefona e vou até lá para recepcionar o recém-nascido. Na equipe temos um bom relacionamento, tanto com os colegas da UTI, do plantão e também com todos do Centro Obstétrico. Com as enfermeiras e auxiliares, vejo que elas tentam conduzir o trabalho da melhor maneira possível para o conforto da mulher e do recém-nascido. $O$ trabalho de parto e o puerpério imediato também. São profissionais boas, comprometidas, sabem o que estão fazendo, são bem preparadas tanto para saber os limites até quando é viável para elas, até quando precisam pedir ajuda do médico obstetra para fazer algum tipo de intervenção. Seja só para se certificar se está tudo certo, para continuar ou indicar outro procedimento. Seja parto cesárea ou fórceps. As equipes se respeitam. Na medida do possível, a humanização acontece aqui de maneira bem adequada. São pouco invasivos no trabalho de parto, evitam fazer episiotomia, estimulam o aleitamento materno logo em seguida do parto, apoio psicológico no transcorrer do trabalho de parto, a presença do familiar, as gestantes são sempre bem orientadas. Às vezes tem muita paciente lá e elas são poucas, mas tentam conduzir o parto da melhor forma possível. O que mais nos cabe na sala de parto é estimular o contato precoce mãe e filho. O bebê, assim que nasce, estando em boas condições, é colocado no contato pele a pele com a mãe. O aleitamento materno é iniciado imediatamente: após o parto já é colocado junto à mãe para começar a sucção. Os bebês são colocados em Alojamento Conjunto desde que possível com a mãe; só se houver algo que contraindique não ficam com a mãe em tempo integral. Elas são auxiliadas pela equipe de enfermagem, mas são as mães que efetivamente cuidam dos bebês. Uma boa assistência em relação ao parto e ao recém-nascido começa muito antes do bebê nascer. Começa muito antes, com um pré-natal bem feito. O problema aqui são as condições sociais dos pacientes que são atendidos. Você vê mães muito pobres com muitos filhos sem condições nenhuma. O pré-natal está aberto a todas, mas muitas não fazem. Mas o pré-natal aqui está aberto para quem quer e são muito bem conduzidos pelas partes da enfermagem e médicos. Acontece também de mãe adolescente que tem todos os exames, 10 consultas, tudo anotado, pré-natal perfeito. Isso reflete muito no trabalho, pois nasce melhor, é rastreado. Quando o pré-natal é bem feito, normalmente o parto acontece muito bem e reflete no meu trabalho. No trabalho de parto propriamente dito, quando as mães estão orientadas, a equipe mais disponível, as coisas acontecem da maneira mais natural possivel: os desfechos são melhores. Fico satisfeito quando vejo que todo mundo trabalhou buscando o melhor resultado e quando consegue fazer o melhor para o paciente. No meu caso, para o recém-nascido. Seja com o bebê que nasceu com apgar 9/10 a termo, seja com o bebê prematuro, que ficou mal e foi para UTI, mas conseguimos fazer as medicações, colocar na UTI, fazer o necessário e esse bebê evolui bem. A equipe toda trabalhando junto para prestar a melhor assistência. Minha experiência é muito positiva, mesmo com todas as dificuldades, dentro de um 
hospital público, conseguimos fazer um trabalho decente. Conseguimos ter bons resultados. É uma experiência bem positiva; claro que vários lugares têm problemas, mas temos dificuldade com a superlotação, não tendo vaga na UTI neonatal e não tem como rejeitar. Se tem um ponto negativo a ressaltar é a superlotação na UTI. Tem estruturas que não são capazes de suprir 100\% das necessidades". 


\section{OS ESQUEMAS CONCEITUAIS, OS DESCRITORES CULTURAIS E O SUBTEMA CULTURAL}

DC1 - Um modelo assistencial implementado para melhorar a assistência obstétrica: o processo de transformação do CO em CPN

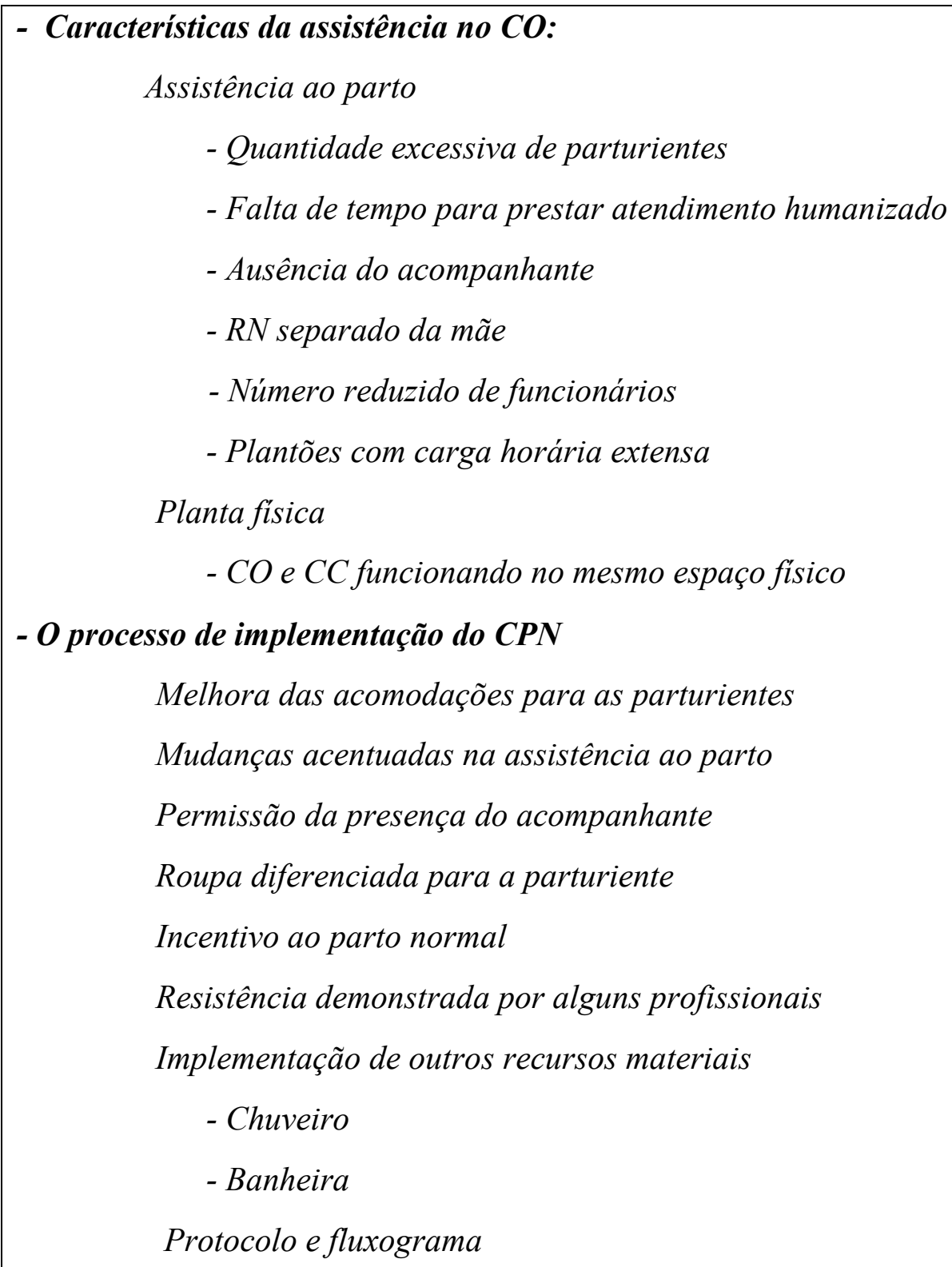


Antes da implementação do CPN, havia no HMMAA um Centro Obstétrico onde eram prestados atendimentos a uma quantidade excessiva de parturientes. Esse número elevado de atendimentos foi referido como um obstáculo para a assistência individualizada, com foco nas necessidades das próprias mulheres. Referiram que, com a falta de tempo necessário para atendimento humanizado, o CO funcionava como uma espécie de "linha de montagem", mediante procedimentos realizados rapidamente, nos quais a mulher era praticamente imperceptível. As mulheres que procuravam atendimento naquela época já possuíam o imaginário a respeito do serviço: um local onde a assistência ao parto era desenvolvida de forma impessoal e com grandes lacunas. Estas mulheres não chegavam a esboçar uma atitude crítica em relação ao atendimento que recebiam.

"Na época o serviço era feito por menos neonatologistas e médicos pediatras. Não tenho certeza, mas talvez por menos obstetrizes. Aparentemente, o atendimento era numericamente maior. Não tinha o mesmo tempo de focar o atendimento humanizado. Era uma linha de montagem que a paciente sabia que seria tratada daquela forma e muitas vezes nem reclamava". $(1,2)$

Era uma época em que as mulheres permaneciam sozinhas porque a presença do acompanhante era proibida. Após o nascimento, o RN era separado da mãe durante várias horas.

\section{Relataram que no $\mathrm{CO}$ existia um número reduzido de funcionários e o} atendimento era prestado por uma quantidade menor de médicos neonatologistas, pediatras e enfermeiras obstétricas. Estes funcionários estavam sujeitos a um regime de plantão com uma carga horária extensa. $O$ trabalho também era muito intenso e era difícil dispor de um período livre durante o plantão. Referiram que não conseguiam dividir o horário com os colegas e nem tirar férias, por causa da falta de funcionários.

"Os plantões eram maiores, 24 horas semanais seguidas. Era dificil ficar um período livre ou dividir horário com os colegas ou plantões de doze horas ou até tirar férias. A falta de profissional era maior do que é agora". (1) 
Quanto à planta física, o CO e o CC funcionavam no mesmo espaço físico. Dessa forma, as cesarianas e os partos normais aconteciam no mesmo ambiente.

Com a implementação do CPN as primeiras mudanças que ocorreram foram as estruturais. Houve a transformação da planta física, com a separação dos ambientes. Foi criado um ambiente separado para a mãe permanecer com o seu acompanhante durante o pré-parto e o parto, o que antes não era permitido. No ambiente do CPN, houve melhora das acomodações e dos materiais e equipamentos. Foi instalado ar condicionado e foram colocadas macas de melhor qualidade.

"Quando cheguei aqui não tinha CPN, somente Centro Obstétrico. Primeiramente, mudaram a questão estrutural para fazer o Centro de Parto Humanizado, porque o parto cesárea era praticamente junto com o parto normal, depois passou a ser separado. Criaram uma área para ficar as mães junto com o acompanhante, que antigamente não tinha, separávamos o bebê da mãe, agora não. O bebê nasceu já fica do lado da mãe, tanto é que o berço fica dentro da sala cirúrgica e a mãe acompanha todos os passos até ficar com ele e ir para o quarto". (2)

"No Centro de Parto a única coisa que tivemos observada melhora foi a parte estrutural física: paredes, piso, ar condicionado, maca para a mãe”. (1)

Referiram, como um dos aspectos positivos na transformação em CPN, a presença irrestrita do acompanhante durante o nascimento. Esta mudança trouxe grandes benefícios para a mãe e também para o acompanhante, que passou a participar de forma mais colaborativa durante todo o processo de nascimento e parto. $\mathrm{O}$ vínculo entre os membros da família foi fortalecido por meio do estímulo para o trinômio permanecer junto neste momento.

"Isto foi uma mudança boa para a mãe e para o companheiro, que fica junto da hora que nasce até o momento que vai para casa. É importante estimular que mãe, pai e bebêfiquem juntos o tempo todo, como também promover a amamentação na primeira hora de vida, pois isso cria um vínculo maior entre mãefilho, que é nossa função principal, a de criar um vínculo maior entre o bebê e a mãe". (2) 
Relataram que ocorreram mudanças no tipo de atendimento prestado às mulheres, depois do advento do CPN. Os profissionais que atuavam diretamente na assistência obstétrica foram os mais atingidos por estas mudanças, por causa da política de humanização dos nascimentos. Referiram que, para eles, enquanto neonatologistas, estas mudanças foram pouco perceptíveis. Os materiais disponíveis também não mudaram muito, porém houve mudança nos protocolos e no fluxograma de atendimento.

\footnotetext{
"O material não mudou muito no atendimento nos últimos anos. Mudou o protocolo, o fluxograma, mas não mudou o material em si. Não teve uma mudança grande para nós, mas para a obstetrícia sim, porque mudou o tipo de atendimento, com uma visão melhor do Centro Cirúrgico para o Centro de Parto Normal, que foi a humanização". (1)
}

Muitos profissionais apresentaram resistência à implementação do CPN. Esses profissionais acreditavam que esta resistência da enfermagem e da classe médica emanava, sobretudo, do aprendizado obtido durante a formação profissional e da cultura desenvolvida nas escolas de médicos e de enfermagem. Estas resistências foram amenizadas por intermédio da frequência a cursos, palestras conscientizadoras do novo modelo assistencial e por meio de exemplos práticos que evidenciavam melhorias na assistência.

\footnotetext{
"Na implantação do CPN houve uma certa resistência da enfermagem e dos médicos, porque cada médico aprendeu de uma maneira diferente em uma cultura diferente, mas essas barreiras foram se retirando aos poucos, através de cursos, aulas, orientações, conforme as pessoas foram vendo que funciona”. (2)
}

Avaliaram que atualmente existem outros recursos disponíveis no parto, como, por exemplo, o chuveiro e a banheira, que favoreceram o atendimento enfocando as necessidades das parturientes.

\footnotetext{
"Os chuveiro, banheira, essa parte realmente mudou $e$ você pode perceber o atendimento mais humano”. (1)
}

Avaliaram também que no CPN existe uma cultura de incentivo ao parto normal. As parturientes que chegam à Maternidade já sabem que há a promoção do parto normal, pois as cesáreas eram realizadas apenas quando havia uma indicação clínica. Avaliaram que até roupa da parturiente era diferenciada 
no CPN, porque não há o rigor de controle da infecção hospitalar, necessário no contex to do CC.

"Essa Maternidade, de seis a sete anos mudou muito. Temos uma cultura de parto normal aqui. As pacientes, em sua maioria, sabem que o parto delas será normal. As cesáreas são feitas com indicações. Em um Centro de Parto Normal a própria roupa que se usa é mais tranquila do que em um lugar em que há cirurgia, onde a assepsia tem que ser muito mais rigorosa”. (4) 
DC2 - Valorização da assistência desenvolvida no Centro de Parto Normal

\section{- Crenças relativas à "boa assistência”}

Assistência Pré-Natal

Promoção do vínculo mãe-filho

Trabalho em equipe

A presença e o suporte do acompanhante

Atenção personalizada à parturiente e família

Domínio do conhecimento técnico

Orientação na alta

Sucesso nos desfechos

- Características da assistência desenvolvida

Estímulo do contato precoce mãe-filho

Clampeamento tardio do cordão

Promoção do acolhimento

Mãe informada sobre local de atendimento prestado ao $R N$

Queda da mortalidade perinatal

Sucesso no cuidado ao RN com peso menor que um quilo

Tentativa de ampliar práticas humanizadas

Equipe experiente de enfermeiras obstetras

- Crenças relativas à humanização no CPN

Respeito à fisiologia do parto

Apoio psicológico

Orientação das gestantes

Cuidados com o RN

- Colocação em calor radiante

- Secagem das vias aéreas

- Estímulo precoce ao aleitamento materno

- Exame físico no $R N$

- Permanência do RN com a mãe

Presença do acompanhante

Horários ampliados de visita 
Houve grande valorização da assistência prestada no CPN, pois avaliaram ser prestada a assistência considerada ideal. Apresentaram inúmeras crenças relativas à "boa assistência". Referiram que esta se inicia na assistência pré-natal.

\author{
"Uma boa assistência, em relação ao parto e ao recém- \\ nascido, começa muito antes do bebê nascer. Começa muito antes, \\ com um pré-natal bem feito". (4, 6)
}

Julgaram que, para que isto ocorresse, havia a necessidade de toda a equipe de médicos, de enfermeiras e, até mesmo, de faxineira ser bem entrosada e possuir o mesmo objetivo assistencial. Avaliaram que o trabalho em equipe estava associado ao treinamento adequado dos funcionários, para que as condutas sejam unânimes e não haja divergências entre eles.

\footnotetext{
"temos que ter o material adequado, funcionários treinados adequadamente, médicos, enfermeiras, faxineiras, todos entrosados no mesmo objetivo". $(2,5)$
}

Julgaram também que, para o binômio mãe-filho receber boa assistência, havia a necessidade da participação da família, pois, quando os acompanhantes participavam ativamente do trabalho de parto e parto, prestavam apoio emocional à parturiente.

"O bebê e a mãe têm que ser bem assistidos, com todos os recursos necessários naquele momento. Com a participação da família, tem um vínculo maior mãe-bebê e com a instituição. Se promove muito mais fácil o aleitamento materno". $(1,4)$

Avaliaram também que, com a presença dos acompanhantes, havia o favorecimento da promoção do vínculo mãe-filho e a sua continuidade após o nascimento. Desta forma, o aleitamento materno tornava-se mais efetivo, pois era estabelecido desde a primeira hora após o parto.

"Uma boa assistência ao bebê é você ponderar o momento em que ele está bem confortável com a mãe após o nascimento e o atendimento mais invasivo, se não ele vai sofrer algum tipo de lesão, por exemplo, o bebê nasce, chora é colocado no colo da mãe”. (1) 
Avaliaram que a atenção personalizada à parturiente e a família era importante na adequação da assistência. Esta atenção era promovida desde o contato inicial com ela e sua família na chegada à instituição. Acreditavam que no momento da chegada da parturiente ao pré-parto, esta deveria ser apresentada aos profissionais que iriam acompanhá-la durante o trabalho de parto, tendo a família para apoiá-la. A família deveria também ser atendida de forma humanizada.

Acreditavam que a mulher deveria ser orientada quanto aos procedimentos a serem realizados, sendo bem informada a todo momento. Atenção especial deveria ser destinada à orientação adequada na alta hospitalar, para que ela tenha conhecimento para prestar os cuidados adequados ao RN no domicílio.

Acreditavam que o domínio do conhecimento técnico é o que deve nortear a tomada de decisão entre parto normal ou cesárea, mediante a observação das indicações corretas.

\footnotetext{
"Uma boa assistência é um pré-natal adequado, as indicações corretas a nível de ciência: se deve ser parto normal ou cesárea, por exemplo. E quando chega na maternidade, saber quem são os profissionais que vão cuidar dela, os seus familiares ao lado para dar apoio, uma atenção humanizada para a família, um pediatra na sala de parto, um assistente para esse pediatra, além de colocar o bebê na primeira hora junto da mãe e na alta uma orientação adequada". (4)
}

As crenças relativas à boa assistência convergiam para o sucesso nos desfechos do processo de nascimento. Ou seja, quando o RN nasce ativo e saudável ou mesmo com intercorrência, o profissional deveria entregar o RN para a sua mãe no alojamento conjunto, de modo a estimular o aleitamento materno.

\footnotetext{
"Uma boa assistência é o desfecho com sucesso do caso. Quando o bebê nasce bem, ou se houver alguma intercorrência, fazer os procedimentos para entregar o bebê para a mãe no alojamento conjunto, no seio materno. A cada dia vou tentando melhorar, como pessoa e profissional". (3)
}

Relataram que as características da assistência desenvolvida no CPN envolviam o estímulo ao contato precoce mãe-filho. Acreditavam que este contato propicia uma sensação de tranquilidade e alívio para a mãe devido à liberação de hormônios que promovem a sensação de satisfação. Quanto ao clampeamento 
tardio do cordão, acreditavam que este consistiu em uma tendência em processo de implementação e ainda não era efetivo em todos os nascimentos.

"Se é um bebê que nasce bem forte, vigoroso, podemos pôlo na barriga dessa mãe antes mesmo de cortar o cordão, para que ela sinta seu bebê e se tranquilize. A nível hormonal é muito importante, pois diminui o sangramento e a dor". $(3,4,6)$

"temos visto a tendência do corte tardio do cordão; esperar pelo menos um minuto, assim o bebê tem o aporte de sangue necessário e não tem tanta anemia”. $(3,4,6)$

Referiram que cabia aos enfermeiros obstetras promover o acolhimento

da mulher, por meio da demonstração de empatia e da orientação contínua durante o processo de parturição. Avaliaram que manter a mulher informada era uma tarefa que cabia a todos os profissionais envolvidos com a assistência. Quanto à promoção de acolhimento, referiram que o neonatologista deveria se identificar junto à mãe e criar um vínculo com ela.

\footnotetext{
"Uma coisa que é boa para a mãe é se sentir bem acolhida antes do parto. $O$ profissional tem que se identificar e explicar o que vai acontecer. Isso tanto o neonatologista, quanto o obstetra e a obstetriz. No nosso caso, nos identificamos e fazemos um elo para que essa mãe se sinta acolhida. Porque às vezes é um parto demorado, no qual essa mãe faz mais força. É importante que tanto o familiar quanto a equipe esteja envolvida”. (4)
}

Relataram que a atenção em relação à parturiente promovia a melhora da qualidade da assistência e ajudava a transformar o modelo assistência vigente.

"A melhor coisa que podemos dar é a atenção, qualquer tipo de atenção extra que damos para a paciente, já melhora $100 \%$, ter educação, conversar; você vai ver que modifica”. (2)

Referiram que cabia ao médico neonatologista mostrar o local de atendimento do $\mathrm{RN}$ para a mãe.

"No caso de um bebê que precisa de aspiração, nosso procedimento é mostrar para a mãe o berço do bebê na sala. (...) Em seguida, esse bebê já volta para a mãe para senti-lo".

Avaliaram que inúmeros progressos foram conquistados desde a implementação do $\mathrm{CPN}$, dentre eles a queda da mortalidade perinatal. O número 
de óbitos também foi reduzido e já havia sucesso no cuidado aos RN com menos de um quilo.

\begin{abstract}
"O serviço está melhorando muito. Já estamos tirando bebês com menos de um quilo. Antes era sonho agora é realidade. A mortalidade perinatal abaixou bastante. Estamos tentando ampliar a humanização. O contato pele a pele, o aleitamento materno na primeira hora de vida junto com a mãe, para melhorar o alojamento conjunto e ter uma descida do leite melhor". (3)
\end{abstract}

Referiram estarem buscando ampliar as práticas humanizadas como o contato pele a pele após o nascimento, o aleitamento materno na primeira hora de vida, pois acreditavam que tudo isso influenciava positivamente o pós-parto mediato.

Quanto à equipe profissional, observaram que havia bom entrosamento entre os membros da equipe, uma boa comunicação e, consequentemente, um trabalho sem estresse.

\footnotetext{
"temos uma equipe boa, coesa, que se comunica sempre, as obstetrizes estão presentes a todo momento, nós estamos sempre indo lá, conversamos, temos um bom relacionamento com os diaristas também (...), assim conseguimos manter um bom trabalho sem estresse". (1)
}

\title{
Relataram que a equipe de enfermeiras obstetras era experiente e
} conduzia o parto da "melhor maneira possível", para o conforto da mulher e dos recém-nascidos. Avaliaram que elas tinham conhecimento técnico, conheciam os seus limites e solicitavam a intervenção do obstetra quando necessário. Avaliaram que, quando a equipe é disponível e focada no trabalho de parto, o parto acontece de “forma mais natural possível” e os desfechos são melhores para a mãe e o RN.

"Com as enfermeiras e auxiliares, vejo que elas tentam conduzir o trabalho de parto da melhor maneira possível, para o conforto da mulher e do recém-nascidos. São profissionais boas, comprometidas, sabem o que estão fazendo, são bem preparadas tanto para saber os limites, até quando é viável para elas, até quando precisam pedir ajuda do médico obstetra para fazer algum tipo de intervenção". $(4,5,6)$

"No trabalho de parto propriamente dito, quando as mães estão orientadas, a equipe mais disponivel, as coisas acontecem da maneira mais natural possivel e os desfechos são melhores". (6) 


\section{Apresentaram algumas crenças relativas à humanização da}

assistência. Acreditavam que a humanização neste CPN estava ocorrendo de maneira adequada porque os profissionais eram pouco invasivos no trabalho de parto, evitavam a episiotomia, prestavam apoio psicológico e as gestantes eram bem orientadas.

"Na medida do possivel a humanização acontece aqui de maneira bem adequada. São pouco invasivos no trabalho de parto, evitam fazer episiotomia, estimulam o aleitamento materno logo em seguida do parto, apoio psicológico no transcorrer do trabalho de parto, a presença do familiar, as gestantes são sempre bem orientadas". (6)

Afirmaram realizar alguns procedimentos, como o exame rápido da mãe, e, quanto ao $\mathrm{RN}$, faziam procedimentos como colocar em calor radiante, secar vias aéreas e realizar o exame físico. A equipe também estimulava o aleitamento materno na primeira hora de vida.

"Na humanização fazemos um exame rápido da mãe, preenchemos uma ficha e fazemos os primeiros passos, que são: colocar sobre o calor radiante, posiciona, seca as vias aéreas, faz os exames físicos para depois ver se tem alguma malformação fisica grosseira". (3) 


\section{DC3 - Dificuldades para o desenvolvimento da assistência no CPN}

- Resistência de alguns profissionais

- Condições sociais das parturientes

- Lotação das dependências físicas

- Quantidade insuficiente de enfermeiros obstetras

- Alta demanda de outras regióes

- Falta de vagas na UTI Neo

- Falta de espaço físico e materiais na UTI neo

- Maior número de internações de RN na UTI

- Falta de conforto na maternidade

- Estresse devido à sobrecarga de trabalho

- Inadequação da formação médica

- Falta de integração dos médicos da UTI e do AC

- Demora no recebimento dos exames solicitados 
Relataram a presença de inúmeras dificuldades para o desenvolvimento da assistência no CPN. Uma delas se referia à resistência de alguns profissionais ao modelo assistencial humanizado. Acreditavam que, sobretudo a classe médica, entendia que no parto humanizado 'nascia igual bicho' porque na condução do trabalho de parto era priorizada a fisiologia. Os neonatologistas, que eram favoráveis a este modelo, diziam que deveria haver uma mudança de mentalidade desses profissionais e que isto seria possível mediante a aproximação aos indicadores positivos obtidos tanto em relação à mãe quanto ao $\mathrm{RN}$.

"Então, tem uma certa resistência dos profissionais com isso, dizer que parto humanizado nasce igual bicho, tem gente que fala 'nasce igual animal', porque não precisa fazer nada, é só deixar nascer, mas temos que mudar a cabeça das pessoas aos pouquinhos verem que é bom, tanto para a mãe quanto para o bebê"’. (2)

Avaliaram que outro fator que dificultava a promoção da assistência eram as condições sociais das parturientes. Muitas mulheres que chegavam à maternidade eram de baixa renda e não tinham realizado o pré-natal.

"O problema aqui são as condições sociais dos pacientes que são atendidos. Você vê muitas mães pobres, com muitos filhos e sem condições nenhuma. O pré-natal está aberto a todas, mas muitas não fazem. (...) Quando o pré-natal é bem feito normalmente o parto acontece muito bem e reflete no meu trabalho". (6)

"O principal para melhorar seria a integração da rede com a Maternidade, no sentido de incentivar um pré-natal bem-feito. Com a reciclagem do médico e até da enfermeira obstetriz, em um incentivo geral para que a gestante não falte”. (4)

Avaliaram que havia alta demanda de mulheres a serem atendidas. Esta demanda elevada resultava na superlotação do CPN, um problema considerado grave, que se associava à problemática da quantidade insuficiente de enfermeiros obstetras. Reconheciam que esses profissionais, dentro das condições oferecidas pelo serviço, se esforçavam para assistir às mulheres.

"Às vezes nascem muitos bebês e não conseguimos dar toda a atenção, por isso precisamos de mais funcionários, percebemos que não tem funcionários para dar o tratamento adequado, as enfermeiras obstetras fazem com o maior esforço, mas algumas vezes não conseguem”. (2) 
Referiram que havia maior número de internações de RN na UTI e que este problema estava associado à alta prevalência de cesarianas.

"Aumentou a incidência de parto cesárea. Hoje tem dia com 10 a 12 cesáreas, porque, para o obstetra, qualquer coisa alterada é melhor intervir para evitar complicação". (3)

O aumento de internações na UTI e a falta de espaço físico provocavam a lotação da UTI neonatal. Avaliaram que, mesmo na falta de vagas, não tinham como rejeitar as internações e tinham que se adaptar a esta situação.

"Temos dificuldade com a superlotação e a falta de vagas da UTI neonatal e não temos como rejeitar. Se tem um ponto a ressaltar é a superlotação da UTI. Tem estruturas que não são capazes de suprir 100\% das necessidades”. (6)

A falta de espaço físico e de materiais na UTI neonatal ocasionavam muito estresse e, consequentemente, havia o risco de adotar condutas inadequadas.

"Tem dias que temos mais de trinta bebês internados em regime de UTI ou semi-UTI, sem ter espaço físico e material, claro que sempre se resolve, aluga-se material, não chega a faltar nada para o bebê, mas o estresse e o volume de trabalho aumentam para o funcionário, logo o risco de uma condução não adequada aumenta também”. (1)

Relataram que havia uma falta de integração dos médicos da UTI com os do alojamento conjunto.

\footnotetext{
"Precisaria mudar um pouco essa dinâmica da UTI e do $A C$, porque falta integração entre os médicos da Unidade de Terapia Intensiva e dos médicos que passam no Alojamento Conjunto. As vezes fica um exame para ver no AC e o médico que está na UTI não quer ver". (5)
}

A intensa demora no recebimento dos exames solicitados foi relatada enfaticamente como sendo um grande problema, pois dificultava a adoção de condutas consideradas necessárias

\footnotetext{
"Um problema que temos é que os exames muitas vezes não chegam na hora que queremos". (4)
}

STC 4 - Dificuldades existem porque são comuns no serviço público, mas estou satisfeito com a assistência prestada no CPN. 


\section{FS: 35 anos, natural de São José dos Campos - SP, doutora pela Universidade Federal de São Paulo, casada. Trabalha na Maternidade há 9 anos.}

"Comecei a trabalhar no Amador no final do ano de 2002. A idéia de se ter fisioterapeutas veio porque os fisioterapeutas trabalham com um enfoque bastante importante principalmente nas questões de métodos não farmacológicos de alívio da dor e porque utilizamos, por exemplo, a lexoterapia, TNS para reduzir a dor, trabalhamos com mobilizações específicas da pelve, massoterapia, foram por esses motivos que resolvemos implantar o serviço de fisioterapia naquele centro. Na época não tínhamos métodos não-farmacológicos de alívio da dor, atendíamos do lado onde hoje é o CO, era um ambiente mais difícil, a mulher não era acolhida, tínhamos seis parturientes por quarto, somente retirávamos a parturiente do leito e andávamos com ela, pela falta de privacidade. Senti resistência quanto à presença da equipe de fisioterapia neste antigo formato. $O$ fato da paciente que ria submetida à cesárea ficar no mesmo quarto da que teria parto normal, causava resistência da equipe conosco porque tirávamos a parturiente do leito e isso implicava algumas vezes em perder o acesso tendo que puncionar novamente. Em 2007, foi feita uma reforma do prédio para ser transformado em CPN e ficou muito melhor. Com o CPN ficou muito mais fácil de trabalhar, porque tem muito mais espaço, tem ar condicionado, tem a estrutura para receber o acompanhante. Quando acontece, por exemplo, de encerrar nosso horário orientamos os acompanhantes para continuarem fazendo a deambulação, os exercícios na bola, massoterapia, técnicas de respiração. O Centro Humanizado foi usado no início do CPN, a banheira só umas duas vezes, depois nunca mais. Acredito que por falta de funcionários, talvez não tenha gente para cobrir geograficamente, porque fica muito distante do pré-parto. Os recursos como bola, chuveiro banquinho por parte dos outros profissionais ainda são pouco utilizados, talvez devido ao pequeno número de funcionários no plantão ou por falta de recursos porque, por exemplo, só tem uma bola que foi a faculdade que deu. Particularmente não gosto daquele cavalinho porque não tem a mobilidade que deveria, então não ajuda, mas quando vejo os profissionais usando esses recursos fico feliz, porque ajuda muito no parto. Acho que desde o início até agora houve um progresso muito grande com relação a forma que deve ser o parto e a forma que deve ser tratada a parturiente, ainda vejo que tem muito a melhorar mas vejo lugares com mais escassez de recursos, de profissional e assistência mais limitada. Para melhorar acho que deveria ter acompanhante sempre, inclusive quando a parturiente fosse para o Centro Cirúrgico, deveria ter um profissional que fizesse efetivamente a prática não farmacológica de alivio da dor e analgesia, poderia ser fisioterapeutas, as enfermeiras obstetras, mas acho que é uma sobrecarga realmente grande para elas,porque pelo número de profissionais que tem acho que não conseguem, além de ter uma bola só para seis leitos. Poderia ter também aquelas banquetas para a parturiente ficar de cócoras e trocar as macas porque aquelas macas do expulsivo são ruins. Acho que muita coisa poderia ser melhorada mas tenho consciência que dentro dos hospitais públicos o Amador tem um diferencial. Percebo que quando tem escolas envolvidas com estagiários a assistência melhora bastante porque tem mais profissional assistindo a parturiente. O Hospital é muito receptivo, valorizam as pesquisas e sempre querem melhorar. Eles tem o que melhorar mas estão tentando, do antigo CO para CPN melhorou 
absurdamente, o bebê fica com a mãe, é levado ao peito logo após o nascimento, isso só acontece agora com o CPN, a prática da episiotomia que está reduzindo muito mais agora do que antes, eu percebo muitas melhoras no serviço."

\section{Pontos relevantes da narrativa:}

- No CO não tinha privacidade pois eram seis parturientes por quarto.

- Profissionais do CO eram resistentes aos fisioterapeutas pelo uso de métodos não-farmacológicos.

- Dentro dos hospitais públicos o Amador tem um diferencial: é muito receptivo, valoriza as pesquisas e sempre quer melhorar.

- A presença de estagiários melhora a assistência, pois aumenta o número de funcionários.

- Do antigo CO para CPN melhorou absurdamente, o bebê fica com a mãe, é levado ao peito logo após o nascimento, tem acompanhante. 


\section{FX: 43 anos, natural de Osasco-SP, $1^{\circ}$. grau completo, solteira. Trabalha na Maternidade há 7 meses.}

"Minha função aqui é limpar as salas e os quartos, não se relacionar muito com os pacientes porque a firma exige. Meu serviço aqui é limpar parede, porta, teto, porta vidro, fazer o terminal todo

sábado. Tenho um bom relacionamento com as funcionárias, com as enfermeiras. Tudo o que estiver em meu alcance, faço para ajudar. Vim para o Amador e vejo que as pessoas são muito bem tratadas. Minha filha ganhou neném aqui. A conduta dos profissionais é muito boa. Fazem mais do que precisa. Gosto muito daqui. Me dou bem com todos: médicos, auxiliares. Quanto aos recursos, acho muito bom os que tem aqui. Apesar de que a sala onde existem mais recursos, do CPN, foi aberta agora só porque houve um vazamento grande na G.O., então trouxeram as coisas para cá. Agora, não sei porque estava fechado. As mães usam a bola, o chuveiro, o cavalinho. Isso tudo é muito bom. Quando entrei aqui minha chefe falou tudo o que eu deveria fazer. Tem dia com muita gente, já outros dias com poucos partos. Na rede de Osasco só tem essa maternidade. Acho que poderiam melhorar não deixando as mães no corredor, sem vaga. Tem mãe que chega a ficar de cinco a seis horas esperando, precisando de um banho. Não é bom porque passam pela dor do parto e ainda têm que esperar deitadas em uma maca dura. Seria bom se tivesse mais médicos. Se estiverem em quatro, poderia ficar dois lá dentro e dois aqui; poderia ser mais rápido. Principalmente no final de semana, pois no final de semana só fica um médico aqui fora e os demais lá dentro. É um descaso total. Vejo isso no dia a dia, porque não tenho folga. Cada equipe age de uma maneira. Tem um médico que é exemplar, mas outros deixam a desejar. Quanto à equipe de enfermagem do meu plantão, são muito boas. Poderia melhorar na estrutura, porque dinheiro tem. Há quartos com camas enferrujadas, sujas, porque os auxiliares não querem limpar e não podemos fazer. Depois acontece uma infecção hospitalar e dizem que foi o pessoal da limpeza. Alguns colchões estão emendados com sacos de lixo. Seria bom se fizessem um novo hospital, pois está vazando para todos os lados e nas reformas começam em um setor não terminam e vão para outro. Acaba não fazendo nada. $O$ GO é um exemplo: está fechado, porque estava entrando água. Esperaram a chuva vir primeiro para depois arrumar. A enfermagem também tem muita culpa, porque, quando tem alguma coisa nova, em poucos dias já quebram. O povo precisa de um serviço bem estruturado, nós pagamos impostos para quando precisar ter. Isso prejudica na boa assistência, no cuidado da mulher. Precisa de um bom colchão, uma boa limpeza, pois o que adianta o chão estar limpo se a cadeira está suja. Precisa que esteja tudo limpo. Para uma boa assistência não podem faltar coisas. Hoje está faltando papel toalha, quer dizer, a rede deixa faltar, mas a paciente precisa disso. Não tem toalha. Como a mãe vai tomar banho e se enxugar em um lençol? Tem que comprar. Não tem travesseiros. Minha experiência tem sido muito boa. Aprendi muito, mas tem muita coisa para melhorar. Gosto muito de trabalhar aqui porque aqui vejo pessoas nascendo. Precisa de pessoas de pulso que digam vamos fazer e façam mesmo, mas vem a política e sabe como é? Acho uma pena um hospital desse porte não atender melhor suas pacientes". 


\section{Pontos relevantes da narrativa:}

- Poderiam melhorar não deixando as mães no corredor, sem vaga.

- Tem mãe que fica cinco a seis horas esperando no corredor.

- Cada equipe age de uma maneira.

- A estrutura e os recursos do hospital estão precários, com muitos vazamentos e recursos.

- Não tem toalha para a mãe tomar banho e se enxugam em um lençol. 


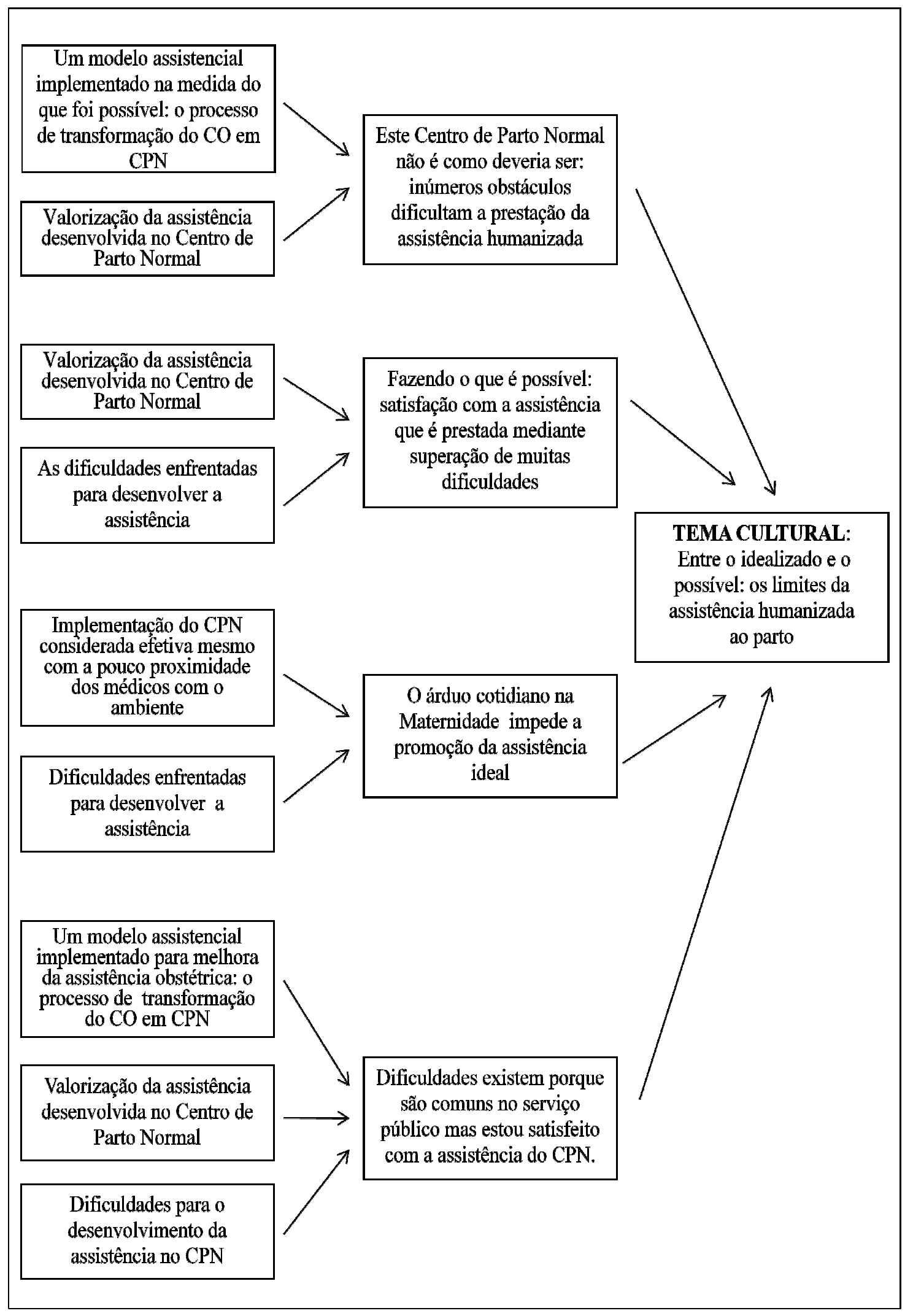




\subsection{O TEMA CULTURAL: ENTRE O IDEALIZADO $\mathrm{E}$ O POSSÍVEL: OS LIMITES DA ASSISTÊNCIA HUMANIZADA AO PARTO}

Os profissionais que colaboraram com o desenvolvimento deste estudo valorizaram a proposta assistencial do Centro de Parto Normal. A implementação do CPN na instituição foi considerada efetiva, principalmente pela presença do acompanhante de escolha. Alguns dos principais aspectos da assistência ao parto valorizados por estes profissionais incluíam o tratamento personalizado e atento às necessidades das parturientes e de seus acompanhantes, as informações fornecidas a elas sobre a progressão do parto, a redução de práticas intervencionistas, a promoção da fisiologia do parto e o uso de métodos não farmacológicos de alívio da dor.

Mesmo considerando efetiva a implementação do CPN, referiram inúmeros obstáculos para promoção da assistência humanizada ao parto e nascimento. Estes obstáculos limitavam o desenvolvimento da assistência considerada ideal dentro do preconizado pela instituição e pelo MS.

Um desses obstáculos teve início com a proposta de criação do CPN, porque os profissionais que estavam representando as suas respectivas categorias, dentre eles médicos obstetras, neonatologistas, enfermeiras obstetras e técnicos de enfermagem, se posicionaram de maneira resistente ao modelo proposto. Eles não aceitavam, com facilidade, a proposta de inovar a assistência obstétrica, resistiam à ideia de possibilitar um acompanhante na assistência ao parto e temiam, sobretudo, grande aumento na carga de trabalho.

Destacaram grandes mudanças em suas crenças relacionadas ao modelo assistencial do CPN à medida que se envolviam com ele e grande parte destes profissionais passou a visualizar a presença do acompanhante sob uma perspectiva positiva, passando a considerá-lo como colaborador da assistência.

Entretanto, observou-se que muitos profissionais ainda tinham grandes resistências em relação a este modelo da assistência ao parto. Alguns neonatologistas 
continuaram a se recusar a promover o contato precoce entre a mãe e seu filho; alguns médicos obstetras internavam mulheres no CPN sem indicação obstétrica, alguns enfermeiros continuavam a realizar manobras obstétricas consideradas proibidas, como, por exemplo, o Kristeller e as episiotomias de rotina.

Avaliaram de forma extremamente negativa o fato da instituição ser a única disponível no município para o atendimento de gestantes portadoras de patologias obstétricas e, além disso, ser referência para municípios vizinhos, que não disponibilizavam atendimento de qualidade para os seus próprios munícipes. Este problema gerava outro, como a recorrente superlotação da maternidade. Em suas narrativas, foi possível observar que muitos dos aspectos de assistência ao parto que valorizavam não chegavam a ser colocados em prática pelos motivos já citados.

Percebeu-se a ocorrência de problemas semelhantes a um efeito em cascata, caracterizados pela superlotação da maternidade, falta de leitos obstétricos, falta de comunicação interpessoal adequada com a parturiente e seu acompanhante, falta de atenção às suas necessidades, deficiências na interação mãe-filho após o parto, clampeamento precoce do cordão umbilical, superlotação da UTI neonatal, entre outros. Este árduo cotidiano assistencial gerava a sensação de desânimo, pois estava associado ao constante déficit de recursos humanos. E somava-se à problemática da estrutura física inadequada e a precariedade dos recursos materiais, dentre eles, a disposição inadequada dos espaços no CPN, a proximidade entre os leitos e a sua separação com uso de cortinas e a consequente limitação da privacidade.

O centro humanizado, que possui suítes de parto e a banheira, permanecia fechado. Neste aspecto, havia discordância de opiniões entre os profissionais. Alguns acreditavam que o motivo era a falta de interesse em sua utilização e outros não compreendiam as razões da não utilização, pois eram favoráveis ao uso deste recurso institucional.

Estes aspectos ora apresentados confirmaram a configuração dos limites entre o que era idealizado e o que era possível de ser feito. Em suas narrativas relataram fazer o que estava ao alcance para promover a melhor assistência, mas enfrentavam obstáculos dos limites impostos pelos recursos disponíveis neste serviço. 
Contudo, foi observado que o possível para eles esbarrava em múltiplos aspectos e não estava ligado somente aos problemas reais quanto à estrutura funcional e física do serviço, aos problemas do acesso ao leito obstétrico ou às questões de financiamento do sistema de saúde. Estavam envolvidas, também, as crenças individuais dos profissionais, a sensibilidade em relação à política de humanização da assistência ao parto, às percepções e expectativas de profissionais e clientes quanto ao parto e sua assistência, entre outros aspectos.

Desta forma, é possível compreender melhor o obstáculo da falta de unanimidade nas condutas, referido como um problema que causava diferenças entre os plantões. Este problema foi justificado pelo desconhecimento dos protocolos institucionais, a falta de educação continuada para os profissionais no serviço, a formação inadequada nas escolas médicas e de enfermagem. Percebeu-se, entretanto, que fortes crenças e valores profundamente arraigados nos profissionais permeavam a assistência ao parto prestada neste CPN.

Portanto, a constatação dos limites entre o que é possível de ser feito e o que é idealizado foi o sentimento que predominou entre o conjunto de profissionais colaboradores deste estudo, tendo em vista que esteve presente em todos os fatores que compõem os subtemas culturais, sendo expresso, com maior ou menor intensidade, nos aspectos da assistência referidos pelos profissionais e pelo processo de OP. 


\section{DISCUSSÃO DOS RESULTADOS, CONSIDERAÇÕES FINAIS E LIMITAÇÕES DO ESTUDO}




\section{DISCUSSÃO DOS RESULTADOS, CONSIDERAÇÕES FINAIS E LIMITAÇÕES DO ESTUDO}

Neste capitulo, os principais resultados da pesquisa foram discutidos à luz da literatura científica. Também foram apresentadas as considerações finais e as limitações do estudo.

\section{$\&$}

\subsection{DISCUSSÃO DOS RESULTADOS}

A análise dos depoimentos dos profissionais que colaboraram com este estudo permitiu observar que consideraram positivo o novo modelo de assistência ao parto implementado no $\mathrm{CPN}$, foco deste estudo. Avaliaram que houve queda nos indicadores obstétricos e neonatais que eram desfavoráveis e puderam perceber que o acolhimento da parturiente era melhor neste ambiente.

Os dados apresentados na literatura científica apontaram que os resultados maternos e neonatais apresentados nos CPN eram favoráveis. Portanto, estes cenários foram apontados como alternativas de assistência ao parto; pois, além de representarem menores taxas de intervenções, a assistência desenvolvida está centrada nas necessidades das próprias parturiente. Consequentemente, o grau de satisfação materna em relação à assistência recebida foi maior (Lobo, 2010; Morano, 2007; Campos, 2007).

Avaliou-se que o modelo do CPN representa um espaço privilegiado para desenvolver e fortalecer um modelo de cuidado apropriado, tanto do ponto de vista conceitual, como em relação à equipe de saúde e à aliança com as mulheres e seus familiares (Riesco, 2009). Segundo foi observado na Maternidade Leila Diniz, no Rio de Janeiro, a resistência dos profissionais à humanização é, aos poucos, superada 
por meio da implementação deste modelo e de oficinas para sensibilização dos profissionais. Progiant (2009) mostrou que estas estratégias na referida Maternidade contribuíram para que muitos profissionais, que assumiam posições contrárias ao modelo de assistência humanizada ao parto, abrandassem as suas resistências, assumindo posicionamento mais favorável à sua implementação. Estes profissionais passaram a valorizar, sobretudo, a presença dos acompanhantes no parto e os benefícios proporcionados por eles, o tratamento personalizado, o estabelecimento de vínculo com a parturiente e a assistência obstétrica com ênfase na preservação da fisiologia da parturição.

Observou-se que semelhante mudança também ocorreu na mentalidade e no modo de conceber a assistência ao parto, entre os profissionais atuantes no CPN estudado. Entretanto, estes profissionais estão enfrentando enormes obstáculos no desenvolvimento da assistência ao parto que desejam prestar às parturientes sob seus cuidados. Os principais obstáculos enfrentados por estes profissionais estavam relacionados ao árduo trabalho que caracteriza o cotidiano assistencial. Este é permeado pela grande demanda de parturientes a serem atendidas, o número reduzido de profissionais, a inadequação da estrutura física e as questões da esfera política. O enfrentamento destes problemas foi referido por profissionais de todas as categorias. Estes se configuram, portanto, como problemas comuns enfrentados nas maternidades públicas brasileiras.

A superlotação das maternidades e a falta de leitos obstétricos levam as parturientes à necessidade de fazer uma verdadeira "peregrinação" em busca de assistência ao parto. Esta precariedade estrutural representa um obstáculo importante para o recebimento de assistência adequada e contribui de modo significativo para o aumento da morbidade e mortalidade materna e neonatal (Tanaka, 1995; Jamas, 2010; Narchi, 2009).

Dados do processo de OP e das narrativas dos profissionais possibilitaram observar que as enfermeiras obstétricas que não tinham tido contatos prévios com o modelo de CPN realizavam a episiotomia e adotavam a posição litotômica na assistência ao parto com menor grau de crítica em relação à própria prática, ou seja, com maior naturalidade. Observou-se também que a episiotomia é 
um procedimento que continua sendo utilizado na prática de assistência ao parto de forma rotineira, pois ainda se acredita que o seu uso facilita nas suturas, previne lacerações, reduz o tempo despendido no parto e previne fraturas de clavícula dos RN.

Acredita-se que a prática da episiotomia de rotina, ou seja, a realização deste procedimento sem critérios clínicos, deve ser veementemente combatida. $\mathrm{Na}$ literatura científica, não há qualquer justificativa para a sua realização de forma rotineira, seja com a finalidade de prevenir lesões na genitália feminina ou dados para o concepto, como a fratura da clavícula (Enkin, 2005). Uma revisão sistemática sobre os efeitos adversos da episiotomia revelou que os danos provocados por este procedimento obstétrico são maiores que os benefícios, sobretudo em relação à disfunção da musculatura perineal, aumento da perda sanguínea, dor, maior risco de infecção, extensão da secção e disfunção sexual (Enkin, 2005; Brasil, 2001; Davidson, 2000).

Observou-se que, embora as camas de parto estejam disponíveis e possibilitem a adoção de outras posições, a maioria dos partos é feita nesta instituição na posição litotômica. Uma pesquisadora desta temática apontou que o uso da posição litotômica dorsal tinha sido adotado por $63 \%$ dos profissionais. O estudo foi feito com o objetivo de analisar a assistência ao parto segundo a perspectiva de enfermeiros atuantes em seis maternidades públicas localizadas na Zona Leste da Cidade de São Paulo. Seus resultados revelaram, entre outros aspectos, que a adoção da posição litotômica na assistência ao parto está associada ao aumento da duração do segundo período clínico do parto (período expulsivo), à maior taxa de intervenções que restringem a participação da mulher, como puxos controlados e manobras de auxílio à expulsão, às alterações da frequência cardíaca fetal, por compressões circulatórias, e à realização de intervenções obstétricas, como a episiotomia (Narchi, 2010).

Existe consenso quanto à necessidade de evitar a posição horizontal durante o período expulsivo do parto. Quanto a este aspecto da assistência, recomendou-se que devem ser respeitados o desejo e as necessidades da própria parturiente em relação à posição de parto que for de sua preferência (Cecatti, 2005). 
A literatura científica demonstra que muitas são as estratégias possíveis para a promoção da assistência humanizada ao parto. As principais dizem respeito ao oferecimento de ambiente aconchegante à parturiente e seu acompanhante, à oferta de líquidos durante o trabalho de parto, à deambulação livre, ao uso dos métodos não farmacológicos para promover alívio dos desconfortos e da dor durante o trabalho de parto e o parto e à promoção da presença do acompanhante de escolha da parturiente. Segundo Castro (2005), tratam-se de estratégias que podem ser facilmente desenvolvidas pela equipe de enfermagem.

Os profissionais que participaram deste estudo demonstraram grande valorização dos métodos não-farmacológicos para alívio da dor no trabalho de parto. A literatura científica demonstrou que estes métodos, que são considerados também como não invasivos, contribuem na redução da sensação dolorosa e proporcionam alívio à parturiente. São considerados métodos não-farmacológicos de alívio da dor: o banho de imersão, a realização de massagens na região lombar e a padronização dos movimentos respiratórios. São recursos que podem ser utilizados de forma isolada ou combinada, pois, além de proporcionarem a sensação de alívio, contribuem para melhorar a experiência em relação à vivência do parto (Davim, 2009).

Em relação à adoção de medidas não farmacológicas de alívio da dor, observou-se que as mais adotadas pelas enfermeiras foram o banho de aspersão e o incentivo à deambulação frequente. A efetividade do banho de aspersão no alívio da dor na fase ativa do trabalho de parto foi comprovada por um estudo realizado na Unidade de Parto Humanizado da Maternidade Escola Januário Cicco, da Universidade Federal do Rio Grande do Norte, onde verificou-se a diminuição significativa da dor, o que comprovou a necessidade da adoção deste procedimento na assistência ao parto (Davim, 2008).

Neste estudo, contatou-se que a presença do acompanhante de escolha da mulher durante o trabalho de parto e parto era um motivo de resistência, sobretudo entre os profissionais que não tinham tido experiências anteriores em instituições que adotavam modelos de assistência humanizada ao parto. Estes profissionais tinham a crença de que os acompanhantes poderiam representar um empecilho à assistência. 
Constatou-se, entretanto, que esta crença foi sendo superada, à medida em que percebiam a importância representada pelo acompanhante.

A promoção da presença do acompanhante de escolha da parturiente constitui uma recomendação do Ministério da Saúde. Este acompanhante pode estar presente deste o pré-natal, continuar no trabalho de parto e parto, de modo a vivenciar, junto com sua parceira, deste momento importante da vida familiar (Brasil, 2001). Uma pesquisadora constatou que a presença do acompanhante provoca reflexos positivos em vários aspectos da assistência ao parto, pois, mediante a adoção desta estratégia, os profissionais conseguiram identificar novas demandas na assistência ao parto. Ressaltou também que a inserção do acompanhante de escolha da parturiente deve integrar uma proposta mais ampla, de humanização da assistência ao parto (Hoga, Pinto, 2007).

A atenção pré-natal deficiente foi referida por todos os profissionais deste estudo como sendo um fator que prejudica a promoção da assistência humanizada no CPN. Alguns relatos feitos por profissionais já apontaram dificuldades na prestação de assistência a parturientes que eram derivadas do preparo inadequado da mulher para o parto (Narchi, 2009). Estes resultados indicam que a assistência humanizada ao parto requer a qualificação de toda assistência obstétrica, desde a assistência pré-natal até a fase puerperal. A criação do Programa de Atenção Integral à Saúde da Mulher (PAISM) evidenciou a importância de atender a saúde da mulher em todo seu ciclo vital, voltando-se ao aperfeiçoamento do controle pré-natal, do parto e puerpério; à abordagem dos problemas presentes desde a adolescência até a terceira idade; ao controle das doenças transmitidas sexualmente, do câncer cervicouterino e mamário (Brasil, 1984; Nagahama, Santiago, 2005).

Quanto às características da assistência prestada pelos médicos obstetras, observou-se a recorrência das internações precoces ou fora de trabalho de parto. Os próprios membros desta categoria profissional tinham a crença de que este problema ocorria em consequência da inexperiência profissional, da pressão para a internação, feita pelos próprios familiares das parturientes, e do receio do surgimento de problemas decorrentes de complicações obstétricas. 
Este dado sugere que estes profissionais devem receber treinamento específico em relação à assistência ao parto em um CPN. Isto implica readequar a formação destes profissionais, de modo que, no período de residência, tenham oportunidade de permanecer em modelos de assistência ao parto humanizado; assim, provavelmente, este tipo de problema não existirá ou será atenuado.

Quanto à assistência desenvolvida pelos médicos neonatologistas, observou-se que estes profissionais realizavam procedimentos, como a aspiração de vias aéreas superiores e a aspiração gástrica, de forma rotineira. Em relação a este aspecto da assistência, as evidências científicas já demonstraram que se tratam de procedimentos que devem ser empregados com indicação.

As evidências científicas apontaram que a maioria dos RN saudáveis não requer aspiração nasal, faríngea ou gástrica. As vias aéreas devem apenas ser aspiradas, de forma criteriosa, mediante utilização de peras de aspiração, ao invés do uso de cateteres de aspiração, pois estes podem provocar lesões nas mucosas e, até mesmo, arritmias cardíacas (Enkin, 2005; Narchi, 2010).

Como na maioria dos partos de baixo risco os $\mathrm{RN}$ nascem saudáveis, recomenda-se que estes sejam avaliados e recebam cuidados sob o olhar de suas mães. Isto pode ser feito no próprio colo materno e durante o contato pele a pele. Foi recomendado que, durante a realização deste procedimento, quando necessário, sejam tomadas precauções para que a temperatura corporal do $\mathrm{RN}$ seja preservada, suas vias aéreas estejam livres e que seja proporcionada uma recepção amistosa para ele (Enkin, 2005).

Os resultados deste estudo demonstraram que a interação mãe-filho após o parto era realizada de maneira inadequada. Alguns médicos neonatologistas possuíam resistências à realização deste procedimento e demonstravam pressa para receber o $\mathrm{RN}$ e prestar-lhe os primeiros cuidados. Estes profissionais relataram que esta maneira de recepcionar o $\mathrm{RN}$ derivava da problemática da alta demanda encontrada no serviço e pelo fato de alguns não avaliarem ser importante a promoção do vínculo entre mãe e seu RN. 
Uma pesquisadora já demonstrou que as principais causas da remoção precoce do $\mathrm{RN}$ eram a ansiedade do profissional e a sua pressa em realizar os primeiros cuidados. Esta problemática se salientava, sobretudo quando os nascimentos ocorriam no final do turno de trabalho ou quando havia sobrecarga de trabalho no setor (Matos, 2010).

Observou-se que, no CPN estudado, a interação mãe-filho era estimulada intensamente, sobretudo quando se aproximava a época da avaliação do serviço, visando o recebimento do título de Hospital Amigo da Criança. Observou-se que esta iniciativa, proposta pelo governo federal, de certa forma contribui para que as práticas assistenciais adotadas nas maternidades se transformem. Essa transformação pode estar associada às bonificações financeiras que são destinadas aos serviços que recebem este título.

Acredita-se que o grande desafio deste âmbito seja a constância e a continuidade nas condutas assistenciais, e não apenas as mudanças restritas ao período de avaliação dos serviços. Acredita-se que esta constância e esta continuidade sejam atributos da equipe responsável pela educação continuada dos profissionais atuantes na instituição, no sentido de que todos os seus membros se envolvam com a proposta de assistência humanizada ao parto, conforme os padrões estabelecidos.

Foi observada a subutilização dos recursos disponíveis no CPN, tendo em vista, por exemplo, a não utilização do Centro Humanizado de parto presente na instituição. Alguns profisssionais acreditavam que o que impedia o uso deste recurso era a distância em que ele estava em relação ao pré-parto e a inadequação da cama de parto e da banheira. Outros profissionais, por sua vez, alegaram que a não utilização do Centro Humanizado era decorrente da falta de vontade dos próprios profissionais.

Percebeu-se, portanto, a existência de conflitos ideológicos entre os profissionais atuantes no CPN estudado. Alguns profissionais se mostraram ativistas da ideia da humanização da assistência ao parto. Outros profissionais, por sua vez, apresentaram uma tendência à continuidade da assistência conforme à maneira empregada rotineiramente em um Centro Obstétrico, onde vigorava o modelo potencialmente tecnocrático. Acredita-se que a existência deste conflito explique a 
divergência nas condutas adotadas na assistência, entre as diversas categorias profissionais e entre os membros de uma mesma categoria.

Conclui-se, portanto, que a falta de unanimidade nas condutas de assistência ao parto e ao RN não derivavam apenas da ausência de um protocolo assistencial, como foi referido por alguns profissionais. Associava-se o fato dos protocolos assistenciais não terem sido levados ao conhecimento do conjunto de profissionais, de forma sistemática, no momento em que estes profissionais se integravam à equipe assistencial. Acrescenta-se o fato de os profissionais serem originários de diferentes escolas, com formações diferenciadas no que diz respeito à assistência obstétrica e neonatal.

Apesar da existência da carência estrutural para a prestação do atendimento à parturiente, verificou-se que cabe aos profissionais realizarem uma avaliação constante das prioridades apresentadas pelas mulheres e prestar-lhes assistência na medida das possibilidades. Constatou-se que as mulheres que tiveram suas prioridades atendidas perceberam o cuidado recebido dos profissionais como tendo sido positivo e demonstraram satisfação com a assistência recebida (Jamas, 2010).

Nos resultados encontrados por este estudo, foi possível constatar a existência de desarmonia entre o que os profissionais acreditam ser uma assistência humanizada ao parto e o que é efetivamente desenvolvido no cotidiano assistencial. A existência desta dissonância entre a teoria e a prática assistencial já foi descrita por Mabuchi (2008). Esta autora aponta a necessidade de que seja oferecido ao profissional um aprendizado teórico/prático que resgate o parto num contexto baseado no respeito, na autonomia, na individualidade e no poder de decisão e de troca entre profissional e parturiente, sendo esta temática tratada em todos os cursos que envolvem o cuidado à mulher no ciclo-gravídico puerperal. Desta forma, por meio da sensibilização dos profissionais, principalmente no aparelho formador, este distanciamento é atenuado. 


\subsection{CONSIDERAÇÕES FINAIS E AS IMPLICAÇÕES PARA O ENSINO E A PESQUISA EM SAÚDE}

A compreensão que se deu ao final desta pesquisa é a de que um grande problema a ser considerado diz respeito ao aparelho formador, que continua preparando profissionais segundo o modelo intervencionista de assistência obstétrica, reiteradamente avaliado pelas pesquisas como sendo inadequado. Um grande desafio deste âmbito está representado pela necessidade de articulação entre a grade curricular dos cursos da área da saúde com os fundamentos da Medicina Baseada em Evidências Científicas. Avaliou-se também que a incorporação da ótica das humanidades, que diz respeito à compreensão dos aspectos culturais envolvidos no cuidado, é imprescindível ao bom exercício profissional na área da saúde (Rattner, 2009).

Apesar do conteúdo das narrativas dos diferentes profissionais envolvidos na assistência ao parto terem apresentado pontos em comum, a existência de algumas peculiaridades nas crenças e nos valores de cada categoria profissional pôde ser observada. Os aspectos culturais que permeiam a assistência ao parto, foco deste estudo, emergiram da subjetividade dos integrantes da cultura e da forma como estes se relacionam uns com os outros, com a instituição e com a própria sociedade.

Observou-se que os aspectos subjetivos dos colaboradores deste estudo também contribuíam na determinação do que era possível ou não de ser feito em termos de humanização da assistência ao parto. Assim sendo, as condutas assistenciais adotadas, que dependiam inclusive da dimensão subjetiva dos profissionais, resultavam daquilo que tinha sido absorvido por eles no decorrer da formação profissional, as experiências vivenciadas anteriormente, assim como a atualização profissional.

Este fato reitera a necessidade de considerar que a mudança de paradigmas para a prática humanizada deve ser inserida na formação dos profissionais de saúde, sobretudo na formação dos enfermeiros obstetras, médicos obstetras e neonatologistas. Evidenciou-se também a pertinência do desenvolvimento da educação continuada nos serviços de saúde, de forma sistematizada. 
É de fundamental importância a existência de serviços que prestam assistência humanizada ao parto para servir de modelo para os estudantes. Porém, é de extrema importância também que os professores estejam comprometidos com o ensino baseado nas evidências. Seguindo esta linha de raciocínio, pode emergir a seguinte pergunta: $\mathrm{O}$ que é possível fazer para mudar o olhar dos professores de medicina (principalmente) e de enfermagem? Deve-se adequar o ensino de saúde e promover constante atualização dos docentes, para que se preste uma assistência pautada nas recomendações nacionais e internacionais.

Devemos considerar que a atualização dos profissionais de saúde deve constituir um processo contínuo, tendo em vista a grande rotatividade que ocorre nos serviços e a constante mudança das concepções acerca da assistência à saúde, o que necessariamente ocorre na assistência ao parto. A assistência obstétrica é um dos ramos da assistência à saúde em que a atualização se mostra mais necessária, tendo em vista as inúmeras novas evidências científicas que são apresentadas na literatura científica.

O movimento da Medicina Baseada em Evidências pretende preencher a lacuna entre a pesquisa qualificada e a prática correta, por meio da busca de evidências que embasam as condutas e os procedimentos. O início deste movimento é atribuído ao epidemiologista Dr. Archie Cochrane. Na medicina perinatal, a primeira revisão sistemática de ensaios clínicos randomizados controlados foi publicada em 1989, por Chalmers et al. - Effetive Care in Pregnancy and Childbirt; na forma eletrônica, foi a Oxford Database of Perinatal Trials. Em 1992 foi desenvolvido o projeto conhecido como Cochrane Collaboration, que contempla as revisões de ensaios clínicos controlados na área de saúde. A partir de então, a prática baseada na evidência é essencial na assistência ao parto, pois surgem centenas de novas evidências nesta área a cada ano (Diniz, 2001).

Os resultados deste estudo podem contribuir na promoção de reflexões a respeito de questões que extrapolam a esfera técnica da assistência ao parto, pois fornecem elementos para a reflexão profunda das crenças e dos valores que permeiam as práticas cotidianas dos profissionais. 
Os resultados indicaram também que o processo de implementação de um CPN requer muito cuidado. Os principais, dizem respeito à preparação sistemática dos profissionais acerca da filosofia assistencial e dos protocolos institucionais, de forma que a equipe multidisciplinar tenha os mesmos propósitos e enfoque à saúde da mulher; ao planejamento da planta física; aos equipamentos adequados para a prática obstétrica humanizada e aos recursos humanos em quantidade suficiente para atender a demanda do serviço.

Acredita-se que a adoção destas medidas é crucial para que outros profissionais não venham a enfrentar as dificuldades que foram referidas pelos profissionais que contribuíram para o desenvolvimento deste estudo. Acredita-se que os principais aspectos ora mencionados fornecem subsídios importantes para a criação e a implementação de políticas adequadas de assistência ao parto.

$\mathrm{Na}$ experiência dos profissionais, o CPN se mostrou como um modelo inovador da assistência obstétrica, apesar das grandes dificuldades enfrentadas. Hoga (2001) descreve que as casas de parto são marcadas por simbologias, dentre elas seu papel de modelo inovador. A casa de parto do município de Sapopemba, estudada por Hoga, foi norteadora das futuras casas de parto e precursora do movimento que busca transformar a cultura institucionalizada no âmbito da assistência obstétrica. Em seu estudo atribuiu-se um grande valor à casa de parto como espaço para inovação das práticas obstétricas, pois é a representação simbólica de um conjunto de ideias guiadas por um paradigma próprio e diferente do vigente no sistema de saúde atual. Ela é o símbolo da necessária transformação da cultura institucionalizada.

O valor simbólico da Casa de Parto demonstrado por Hoga (2001) e o demonstrado no CPN deste estudo salientam a importância da implementação em maior escala deste modelo no SUS, bem como a permanência dos que já existem, visto que muitos têm sofrido repressões e ameaças de fechamento.

Constatou-se que, em síntese, o $\mathrm{CPN}$, caso consiga superar todos os obstáculos que se impõem em sua proposta de prestar assistência humanizada ao parto, constitui ambiente propício para a promoção das práticas humanizadas em outros serviços que venham a ser propostos e implementados. 
O que é possível fazer para propiciar que as mulheres assumam o protagonismo do nascimento de seus filhos? Em serviços de saúde com cultura institucional de instituições totais, será mais difícil que nos que já adotam algum conteúdo de humanização (Rattner, 2009). Porém, mesmo nos que adotam algum conteúdo, como é o caso do CPN de estudo, existem obstáculos para que o paradigma humanista seja efetivado.

O enfoque dado a este estudo revela que se faz necessária uma reconfiguração cultural que vai além do ambiente físico. Devem ser direcionadas propostas que englobem as concepções dos indivíduos e trabalhem em suas crenças e valores por meio da conscientização da eficácia, da segurança, do conforto e do bemestar que as medidas pautadas nas evidências e centradas na necessidade das parturientes oferecem.

Pode-se afirmar, portanto, que há a necessidade de se enfocar novos estudos sobre como gerar a mudança da cultura dos serviços.

\subsection{LIMITAÇÕES DO ESTUDO}

Como muitos estudos, este apresenta algumas limitações. Apesar da inserção da pesquisadora no campo de maneira intensa, a compreensão em profundidade dos aspectos culturais envolvidos com a assistência pode ter sido prejudicada pelo tempo restrito do estudo.

O fato de a pesquisadora ser uma profissional graduada em obstetrícia na EACH-USP, com os preditivos da humanização da assistência ao parto, pode ter impedido os profissionais de relatarem suas práticas como realmente acontecem no dia a dia. Porém, esta situação pôde ser atenuada pelo período de observação participante, pelo reconhecimento da pesquisadora como "nativa" da cultura e pelo fato da pesquisadora não ser funcionária da instituição.

A dificuldade de a pesquisadora permanecer no consultório do prontoatendimento, pelo espaço limitado e pelo possível constrangimento da mulher 
atendida e sua família, pode ter prejudicado no aprofundamento da observação participante dos médicos obstetras. 


\section{REFERÊNCIAS BIBLIOGRÁFICAS}




\section{REFERÊNCIAS BIBLIOGRÁFICAS}

Neste capitulo as referências bibliográficas são apresentadas seguindo o estilo Vancouver, sistema autor-data.

Angrosino M. Etnografia e observação participante. Porto Alegre: Artmed Editora, $138 p ; 2009$.

Becker HS. Métodos de pesquisa em ciências sociais. São Paulo: Ed. Hucitec;1993.

Benevides R, Passos E. A humanização como dimensão pública das políticas de saúde. Rev. Ciência e saúde coletiva. 2005; 10(3):561-571.

Bittencourt MNT. Implantação do programa casa de parto no Estado da Bahia. Rev Bras Enferm. 1984;37(2):135-8.

Brasil. Ministério da Saúde. Assistência integral à saúde da mulher: bases de ação programática. Centro de Documentação do Ministério da Saúde, Brasília, 1984.

Brasil. Ministério da Saúde. Comissão Nacional de Ética em Pesquisa. Conselho Nacional de Saúde. Resolução MS-196/96. Normas regulamentadoras de pesquisa envolvendo seres humanos. Brasília; $1996 \mathrm{~b}$.

Brasil. Ministério da Saúde. Portaria GM n.985, de 5 de agosto de 1999. Dispõe sobre criação, normas, critérios, atribuições, definições das características físicas e recursos humanos para o funcionamento do Centro de Parto Normal (CPN) no âmbito do SUS. In: Brasil. Diário Oficial da União, Brasília; 1999 p. 51.

Brasil. Ministério da Saúde. Portaria MS/GM no 569, 01 de junho de 2000. [Acesso em 22 jan 2011]. Disponível em: URL:http://www.saude.gov.br/Programas/ mulher/ 
Brasil. Ministério da Saúde. Secretaria de Políticas de Saúde. Área Técnica de Saúde da Mulher. Parto, aborto e puerpério: assistência humanizada à mulher. Brasília: Ministério da Saúde; 2001. 199p.

Brasil. Ministério da Saúde. Assistência pré-natal: manual técnico. Brasília: MS; 2000 .

Campbell R, Macfarlane A, Hempsall V, Hatchard K. Evaluation of midwid-led care provided at the Royal Bournemouth Hospital. Midwifery. 1999;15(3):183-93.

Campos SEV, Lana FCF. Resultados da assistência ao parto no Centro de Parto Normal Dr. David Capistrano da Costa Filho em Belo Horizonte, Minas Gerais, Brasil. Cad. Saúde Pública. 2007; 23(6):1349-1359.

Casate JC, Correa AK. Humanização do atendimento em saúde: conhecimento veiculado na literatura brasileira de enfermagem. Rev Lat-Am. Enfermagem. 2005 ; 13(1):105-111.

Cecatti JG, Calderón IMP. Intervenções benéficas durante o parto para a prevenção da mortalidade materna. Rev Bras Ginecol Obstet. 2005; 27(6): 357-65.

Chalmers, B. WHO Appropriate Technology for Birth Revisited. British Journal of Obstetrics and Gynaecology. 1992; Vol 99, pp709-710.

Cochrane, AL. Foreword. In I Chalmers, M Enkin \& MJNC Keirse (eds.) 1989. Effective care in pregnancy and childbirth. Oxford University Press, Oxford;1989.

Da Matta R. O ofício do etnólogo ou como ter "Anthropological Blues”. In: Nunes, EO. A Aventura sociológica. ZAHAR Editores, p.24-35; 1981.

Da Matta R. Relativizando: uma introdução a antropologia social. 4 ed. Rio de Janeiro: Rocco, p.143-73; 1993. 
Davidson K, Jacoby S, Brown MS. Prenatal perineal massage: preventing lacerations during delivery. J Obstet Gynecol Neonatal Nurs. 2000; 29(5):474-9.

Davis-floyd R, Sargeant C. Introduction. In: Davis-Floyd R, Sargeant C. (eds.). Childbirth and authoritative knowledge - cross-cultural perspectives. Berkeley and Los Angeles, University of California Press; 1997.

Davim RMB, Torres GV. Avaliação do uso de estratégias não farmacológicas no alívio da dor de parturientes. Rev. RENE. 2008; 9(2):64-72.

Davim RMB, Torres GV, Dantas JC. Efetividade de estratégias não farmacológicas no alívio da dor de parturientes no trabalho de parto. Rev. Esc. Enferm. USP. 2009; 43(2):438-45

Denzin NK, Lincoln, YS. The sage handbook of qualitative research. Thousand Oaks: Sage; 2005.

Deslandes SF. A ótica de gestores sobre a humanização da assistência nas maternidades municipais do Rio de Janeiro. Ciência \& Saúde Coletiva. 2005; 10(3):615-626.

Diniz CSG. Entre a técnica e os direitos humanos: possibilidades e limites das propostas de humanização do parto. Tese de doutorado. Faculdade de Medicina/ USP, São Paulo; 2001.

Diniz CSG. Humanização da Assistência ao Parto no Brasil: os muitos sentidos de um movimento. Ciências e Saúde Coletiva. 2005; 10(3):627-637.

Enkin M, Keirse MJNC, Neilson J et al. Guia para atenção efetiva na gravidez e no parto. 3a ed. Rio de Janeiro: Guanabara Koogan; 2005.

Fundação Perseu Abramo; 2010. Disponível em http://www.fpa.org.br/sites/default/files/pesquisaintegra.pdf 
Gaskin IM. Ina May’s Guide to Childbirth. Bantan Books, Nova York; 2003.

Geertz C. A interpretação das culturas. Rio de Janeiro: ZAHAR, 274p; 1978.

Geertz C. O impacto do conceito de cultura sobre o conceito de Homem. In: Geertz C. A interpretação das culturas. Rio de Janeiro: LTC, p.45-66; 1989.

Gualda DMR. Eu conheço minha natureza: a expressão cultural do parto. Curitiba: Ed. Maio; 2002.

Hodnett ED. Home-like versus conventional institutional settings for birth (Cochrane Review). The Cochrane Library, Issue 2, 2003. Oxford: Update Software; 2003.

Hoga LAK. Inovação da assistência e preservação da tradição: um olhar transcultural das casas de parto de São Paulo e de Osaka. [tese livre-docência]. São Paulo: Escola de Enfermagem, Universidade de São Paulo; 2001.

Hoga LAK, Pinto CMS. Assistência ao parto com a presença do acompanhante: Experiências de profissionais. Investigación y Educación en Enfermería [en línea] 2007, vol. XXV. Disponible en Internet: http://redalyc.uaemex.mx/src/inicio/ArtPdfRed.jsp?iCve=105216848008.

Jamas MT. Assistência ao Parto em um Centro de Parto Normal: narrativas das puérperas [dissertação]. São Paulo: Escola de Enfermagem, Universidade de São Paulo; 2010.

Janesick VJ. The dance of qualitative research design: metaphor,methodolatry, and meaning. In: Denzin NK, Lincoln YS. Strategies of qualitative inquiry. Thousand Oaks: Sage, p.35-55; 1998.

Jordan B. Birth in four cultures: a cross-cultural investigation in Yucatán, Holland, Sweden and the United States. (4a ed.). Ill. Waveland Press, Prospect Heights; 1979.

Kay M. Antropology of Human Birth. Philadelphia: F. A. Davis Co.; 1982. 
Largura M. Assistência ao parto no Brasil: aspectos espirituais, psicológicos, biológicos e sociais. Uma análise crítica. Por um parto mais humano e solidário. $2^{\mathrm{a}}$ ed. São Paulor; 2000.

Leininger MM, Mcfarland MR. Culture care diversity and universality : a worldwide nursing theory, 2. Ed. Massachusetts : Jones and Barlett.Inc ; 2006.

Lévi-strauss C. “Place de l'Anthropologie dans les Sciences Sociales et problèmes posés par son enseignement", in Anthropologie structurale, Paris, Plon, p. 377$418 ; 1954$.

Lobo SF, Oliveira SMJV, Schneck A, Silva FMB, Bonadio IC, Riesco MLG. Resultados maternos e neonatais em Centro de Parto Normal peri-hospitalar na cidade de São Paulo, Brasil, Rev Esc Enferm USP. 2010; 44(3):812-8

Mabuchi AS, Fustinoni SM. O significado dado pelo profissional de saúde para trabalho de parto e parto humanizado. Acta Paul Enferm. 2008;21(3):420-6.

Machado NXS, Praça NS. Infecção Puerperal em Centro de Parto Normal: ocorrência e fatores predisponentes. Rev Bras Enferm. 2005;58(1):55-60.

Magnani JGC. De perto e de dentro: notas para uma etnografia urbana. Revista Brasileira de Ciências Sociais. 2002; 17(49):11-29.

Magnani JGC. Etnografia como prática e experiência. Horizontes Antropológicos.2009; 15(32):129-156.

Malinowski; 1930: apud Herzberg, E. "Aspectos Psicológicos da gravidez e suas relações com a Assistência Hospitalar", dissertação de mestrado USP; 1986

Matos TA, et al. Contato precoce pele a pele entre mãe e filho: significado para mães e contribuições para a enfermagem.Rev Bras Enferm, Brasília. 2010; 63(6): 9981004. 
Morano S, Cerutti F, Mistrangelo E, Pastorino D, Benussi M, Costantini S, et al. Outcomes of the first midwife-led birth centre in Italy: 5 years' experience. Archives of Gynecology and Obstetrics 2007;276(4):333-337.

Morse JM. Designing funded qualitative research. In: Denzin NK, Lincoln YS. Strategies of qualitative inquiry. Thousand Oaks: Sage, p. 56-85; 1998.

Morse JM, Swanson JM, Kuzel AJ. The nature of qualitative evidence. California: Sage, p. 187-200; 2001.

Nagahama EEI, Santiago SM. A institucionalização médica do parto no Brasil. Ciênc Saúde Coletiva. 2005;10(3):651-6.

Narchi NZ. Atenção pré-natal por enfermeiros na Zona Leste da cidade de São Paulo - Brasil. Rev Esc Enferm USP 2010; 44(2):266-73.

Narchi NZ. Atenção ao parto por enfermeiros na Zona Leste do município de São Paulo . Rev Bras Enferm. 2009; jul-ago; 62(4): 546-51.

Organização Mundial da Saúde. Assistência ao parto normal: um guia prático. Genebra; 1996.

Osava RH. Assistência ao parto no Brasil o lugar dos não médicos [tese]. São Paulo: Faculdade de Saúde Pública, Universidade de São Paulo; 1997.

Patton MQ. Qualitative evaluation and research methods.2nd ed.. Thousand Oaks, CA, US: Sage Publications, 532p.; 1990.

Progianti JM, Mouta RJO. Enfermeira obstetra e humanização da assistência. Rev. enferm. UERJ, Rio de Janeiro, 2009; 17(2):165-9.

Rattner D. Humanização na atenção a nascimentos e partos: ponderações sobre políticas públicas. Comunicação saúde educação. 2009;13(1):759-68. 
Riesco MLG, Oliveira SMJV, Bonadio IC, Schneck CA, Silva FMB, Diniz CSG, Lobo SF, Saito E. Centros de Parto no Brasil: revisão da produção científica. Rev Esc Enferm USP. 2009; 43(Esp 2):1297-302.

Sanday PR. The ethnographic paradigm. In Administrative Science Quarterly,p. 527538; 1979

Sandelowski M, Barroso J. Reading qualitative studies. Intern J Qual Methods 2002;

1(1): Article 5. [homepage na Internet]. Alberta; 2002. [citado 20 set 2008].

Disponível em

http://www.ualberta.ca/ iiqm/backissues/1_1Final/html/sandeleng.html

Schatzman L, Strauss AL. Field research: strategies for a natural sociology. New Jersey: Prentice-Hall, INC., Englewood Cliffs; 1973.

Spradley JP. Participant observation. New York: Holt, Rinehart and Winston Ed.;1980.

Tanaka ACA. Maternidade: dilema entre nascimento e morte. São Paulo: Hucitec; 1995.

Uchoa E, Vidal JM. Antropologia médica: elementos conceituais e metodológicos para uma abordagem da saúde e da doença. Cad Saúde Públ. 1994; 10:497-504. 
ANEXO 1

UNIVERSIDADE DE SÃO PAULO ESCOLA DE ENFERMAGEM

Av. Dr. Enéas de Carvalho Aguiar, 419 - CEP 05403-000 Tel.: (011) 3061-7548/8858 - Fax: (011) 3061-7548 Săo Paulo - SP - Brasil

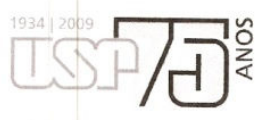

São Paulo, 22 de outubro de 2009.

Ilm. ${ }^{a}$ Sr. $^{\text {a }}$

Michelly Christiny Marcondes Nunes

Ref.: Processo $n^{\circ}$ 857/2009/CEP-EEUSP

Prezada Senhora,

Em atenção à solicitação referente à análise do projeto "Crenças, valores e práticas na assistência ao nascimento humanizado: a ótica dos gestores e profissionais”, informamos que o mesmo foi considerado aprovado pelo Comitê de Ética em Pesquisa da Escola de Enfermagem da Universidade de São Paulo (CEP/EEUSP).

Analisado sob o aspecto ético-legal, atende às exigências da Resolução ${ }^{\circ}$ 196/96 do Conselho Nacional de Saúde.

Esclarecemos que após o término da pesquisa, os resultados obtidos deverão ser encaminhados ao CEP/EEUSP, para serem anexados ao processo.

Atenciosamente,

Maria fat fumandes

Prof. ${ }^{\mathrm{a}}$ Dr. ${ }^{\mathrm{a}}$ Maria de Fátima Prado Fernandes

Coordenadora do Comitê de Ética em Pesquisa da

Escola de Enfermagem da Universidade de São Paulo 


\section{APÊNDICE 1}

\section{CONSENTIMENTO ESCLARECIDO AOS PROFISSIONAIS}

\section{Termo de Consentimento Livre e Esclarecido aos Profissionais}

Você está sendo convidado para participar da pesquisa "Crenças e Valores que norteiam as Práticas dos Profissionais no Centro de Parto Normal". O principal objetivo deste estudo é compreender as crenças e valores que norteiam as práticas dos profissionais envolvidos com a assistência ao parto e nascimento humanizado. Para isso são necessários alguns esclarecimentos:

1. Serão utilizadas como técnicas de coletas de dados - a observação participante e a entrevista;

2. A participação será espontânea, garantindo-se a preservação da identidade, sendo adotado um nome fictício quanto a sua participação neste trabalho;

3. As informações obtidas serão tratadas sob absoluto sigilo e anonimato e fielmente relatadas pela pesquisadora;

4. A qualquer momento o colaborador poderá desistir da pesquisa, não sofrendo qualquer tipo de sanção ou prejuízo;

5. A pesquisadora estará disponível para quaisquer esclarecimentos que se fizerem necessários quanto ao assunto abordado, durante a realização da pesquisa, conforme endereço e telefone constantes abaixo.

6. O colaborador ficará com uma cópia deste termo de consentimento, ficando outra com a pesquisadora.

São Paulo, de de

\section{Assinatura do(a) colaborador(a) da pesquisa}

\section{Michelly Christiny Marcondes Nunes (Pesquisadora)}

E-mail: mirenovada@usp.br

Telefone e endereço para contato ou esclarecimentos com as pesquisadoras: Escola de Enfermagem da Universidade de São Paulo (EE/USP)

R. Dr Enéas de Carvalho Aguiar, 419, cep 05422-970

$$
\text { São Paulo - SP. Tel: (11) }
$$

Telefone e endereço do Comitê de Ética em Pesquisa:

Escola de Enfermagem da Universidade de São Paulo (EE/USP)

R. Dr Enéas de Carvalho Aguiar, 419, cep 05422-970

São Paulo - SP. Tel: (11) 3061-7548

Comitê de Ética em Pesquisa 